Florida International University FIU Digital Commons

\title{
Trans Terrains: Gendered Embodiments and Religious Landscapes in Yogyakarta, Indonesia
}

David B. Esch

Florida International University, davidbrianesch@gmail.com

DOI: $10.25148 /$ etd.FI15050203

Follow this and additional works at: https://digitalcommons.fiu.edu/etd

Part of the Lesbian, Gay, Bisexual, and Transgender Studies Commons, Religious Thought, Theology and Philosophy of Religion Commons, and the Social and Cultural Anthropology

Commons

\section{Recommended Citation}

Esch, David B., "Trans Terrains: Gendered Embodiments and Religious Landscapes in Yogyakarta, Indonesia" (2015). FIU Electronic Theses and Dissertations. 1829.

https://digitalcommons.fiu.edu/etd/1829 


\title{
FLORIDA INTERNATIONAL UNIVERSITY \\ Miami, Florida
}

TRANS TERRAINS: GENDERED EMBODIMENTS AND RELIGIOUS LANDSCAPES IN YOGYAKARTA, INDONESIA

\author{
A thesis submitted in partial fulfillment of the \\ requirements for the degree of \\ MASTER OF ARTS \\ in \\ RELIGIOUS STUDIES \\ by \\ David Brian Esch
}


To: Dean Michael R. Heithaus

College of Arts and Sciences

This thesis, written by David Brian Esch, and entitled Trans Terrains: Gendered Embodiments and Religious Landscapes in Yogyakarta, Indonesia, having been approved in respect to style and intellectual content, is referred to you for judgment.

We have read this thesis and recommend that it be approved.

Jason Ritchie

lqbal Akhtar

Whitney Bauman, Major Professor

Date of Defense: March 26, 2015

The thesis of David Brian Esch is approved.

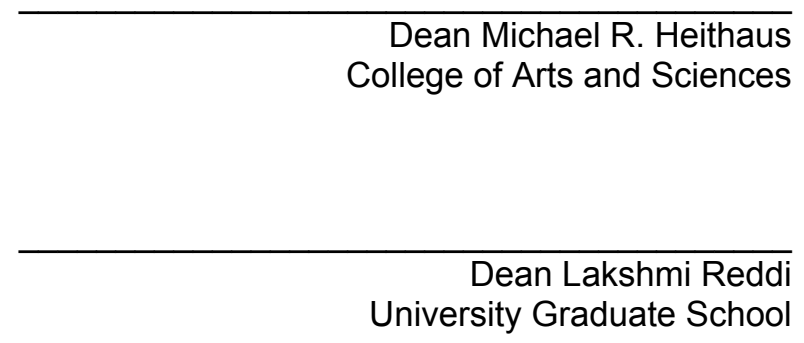

Florida International University, 2015 


\section{DEDICATION}

To the Pesantren Waria Al-Fatah, for opening hearts and minds in the spirit of the Prophet and in the Light of the Bestower of Form and Compassion.

I also dedicate this work to my LGBTQ tribe who is murdered every day because others are not yet capable of seeing.

And to Linda, Lynn, and Michael, better known as Mom, Dad, and Brother.

Thank you for your love. 


\section{ACKNOWLEDGMENTS}

I wish to thank my committee for their guidance with this thesis, especially my major advisor, Dr. Whitney Bauman, who encouraged me to strap on the abject bringing what is outside in, and Dr. Iqbal Akhtar for contributing to my understanding of Islam in its Sufi flavor. I want to acknowledge the professors that have imparted their knowledge and kindness to the larger project that is me: Dr. Christine Gudorf for her warm and brilliant advice on theory and Indonesian culture; Dr. Steven Vose for his love of the iconic, aniconic, and iconoclastic; Dr. Nathan Katz for his passionate and engaging courses in Indian religions; Dr. Albert Wakau for his aid on how to ask the right question at the right time; Dr. Dennis Wiedman who revealed how the qualitative can parlay into the quantitative for a stronger analysis, and Dr. Kimberly Harrison for elucidating the

consequences of rhetorical context. I also wish to thank the Department of Religious Studies and Department of English at Florida International University for their succor during my graduate program.

I am inspired by the members of the waria community for their courageous spirits and silver tongues; this work would not have been possible without their grit, guts, and graciousness. I have benefited from the support of Gadjah Mada University's Center for Religious and Cross-Cultural Studies program and the generosity of a Henry Luce Fellowship. This project was also made possible by all the friends who transcribed and translated, the colleagues who commented and critiqued, and a family who challenges me to listen and love deeper. Lastly, I wish to thank the students in my classroom who ever-expand my angle of vision and remind me that a quality of connection is what makes for persuading others into more joy and power. 


\section{ABSTRACT OF THE THESIS}

TRANS TERRAINS: GENDERED EMBODIMENTS AND RELIGIOUS LANDSCAPES IN YOGYAKARTA, INDONESIA

by

David Brian Esch

Florida International University, 2015

Miami, Florida

Professor Whitney Bauman, Major Professor

Transgendered Indonesians live in the fourth most populated nation in the world with more Muslims than any other country. This thesis summarizes an ethnography conducted on one religiously oriented male-to-female transgender community known in the city of Yogyakarta as the waria. This study analyzes the waria's gender and religious identities from an emic and etic perspective, focusing on how individuals comport themselves inside the world's first transgender mosque-like institution called a pesantren waria. The waria take their name from the Indonesian words wanita (woman) and pria (man). I will chart how this male-to-female population create spaces of spiritual belonging and physical security within a territory that has experienced georeligio-political insecurity: natural disasters, fundamentalist movements, and toppling dictatorships. This work illuminates how the waria see themselves as biologically male, not men. Anatomy is not what gives the waria their gender, their feminine expression and sexual attraction does. Although the waria self-identity as women/waria, in a religious context they perform as men, not women. 


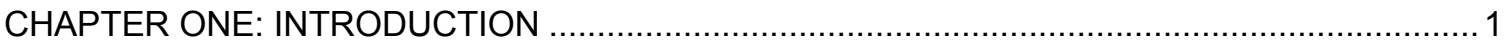

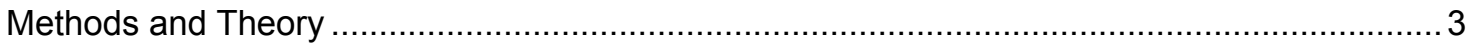

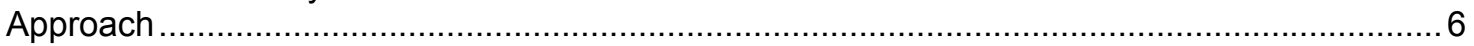

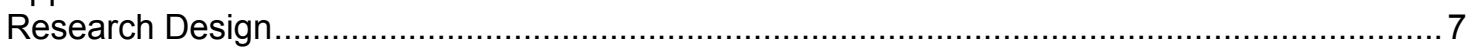

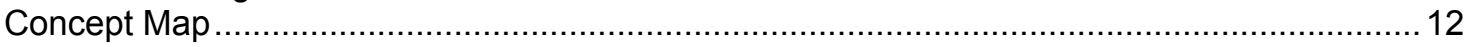

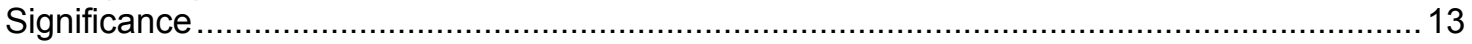

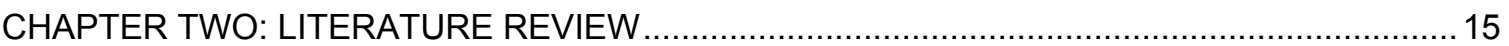

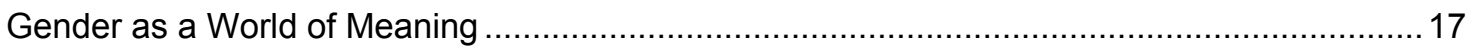

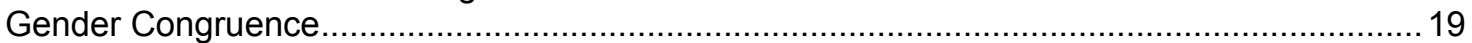

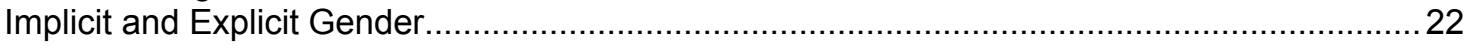

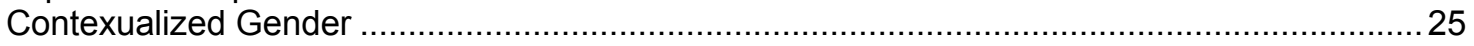

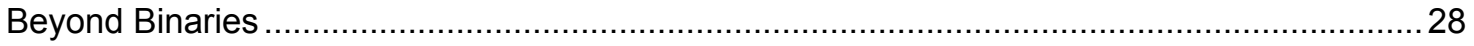

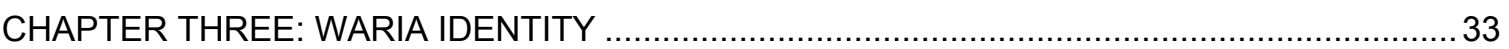

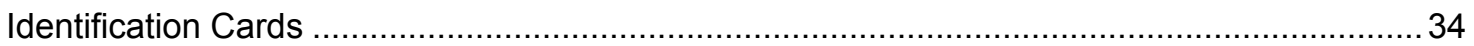

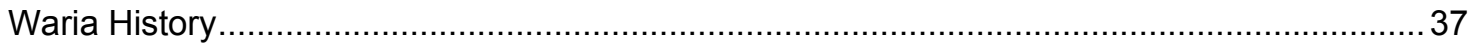

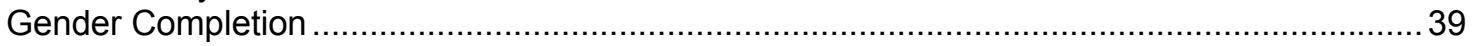

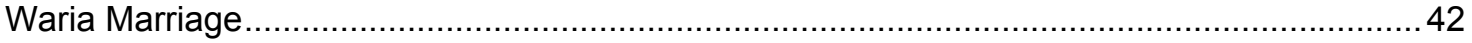

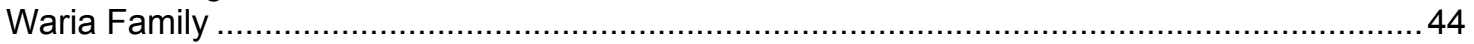

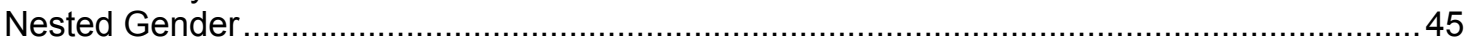

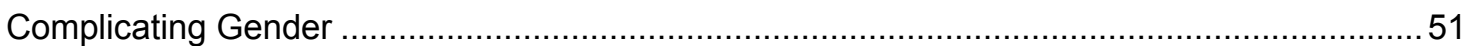

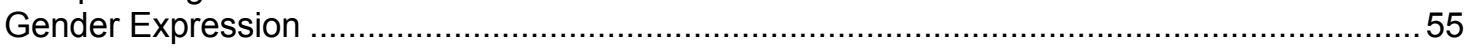

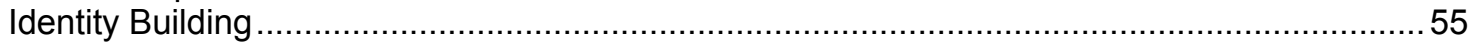

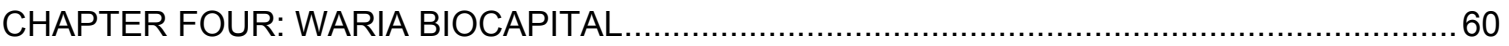

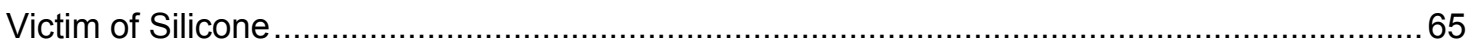

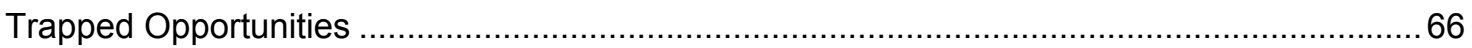

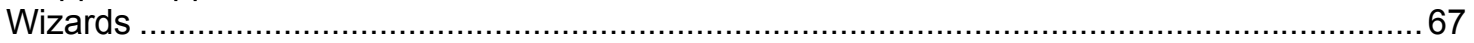

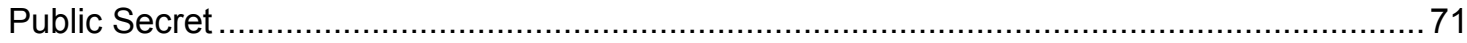

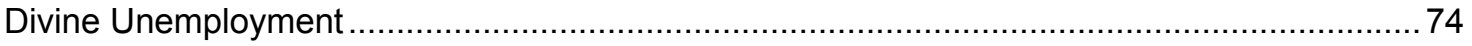

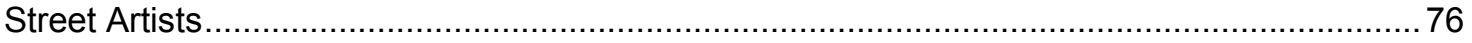

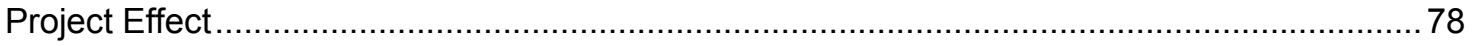

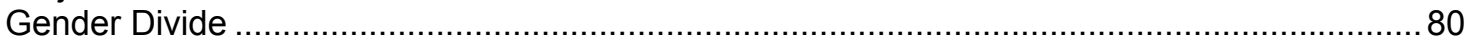

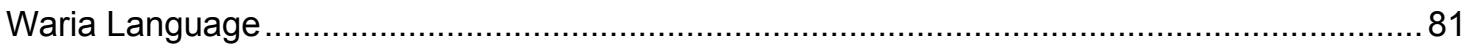

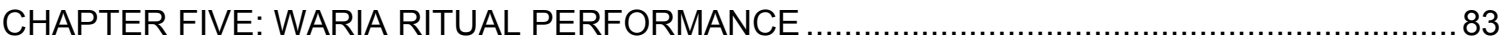

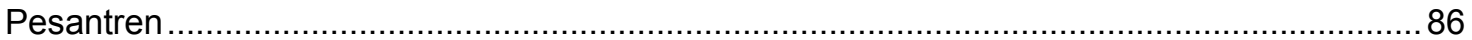

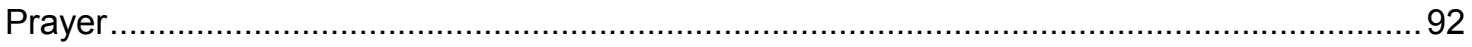

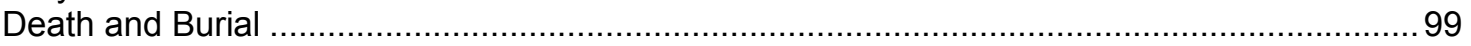

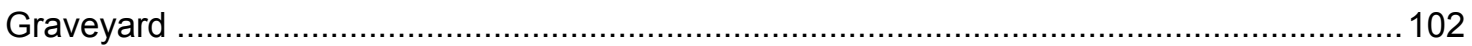

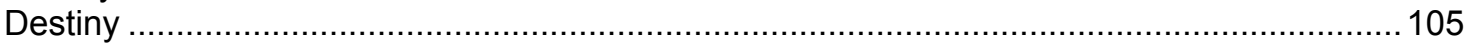

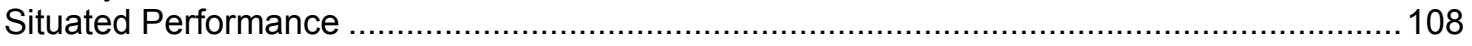

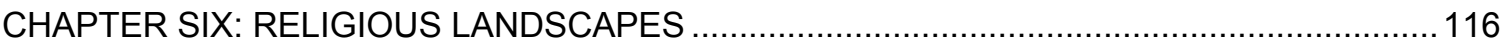

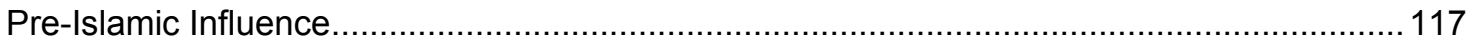




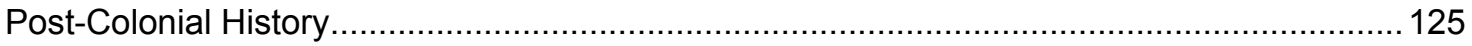

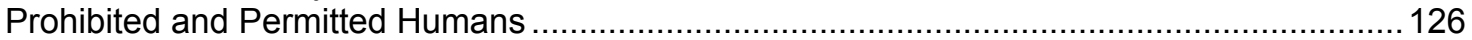

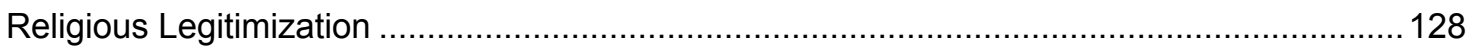

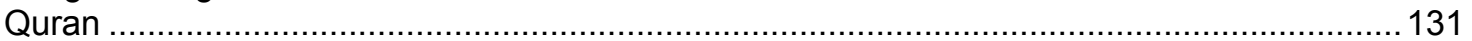

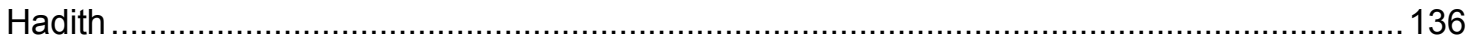

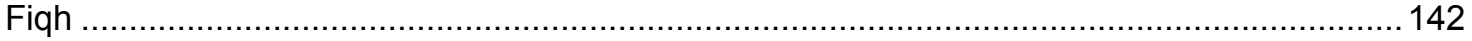

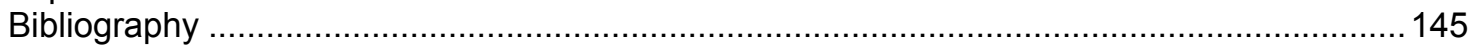




\section{CHAPTER ONE: INTRODUCTION}

Prostitutes ply their trade on the train tracks near Marlioboro steet-the central downtown drag of the city. The moonlit tracks, just off the loading platform, keep the scattering of highheeled waria in enough shadow to surreptitiously scuttle over the rocky ground should police, whose station is only few hundred yards away, make an appearance. Small groups of teenage boys and single men slowly pass as the waria subtly vie for attention with coquettish glances. Ramadhan ended four days ago, so business is starting to pick up. I recognize Merah sitting alone on the other side of the tracks I am strolling down. My phone flashlight helps keep me from tripping over the unfamiliar terrain of grass, rock, and metal. Merah rises to warmly greet me, while a few potential customers begin to approach from the opposite side. Merah turns her body towards the young men non-verbally queuing my exit. I'm not helping to lubricate the social intercourse taking place in this economy of appearances. I casually step away from the merchandise on sale and whisper with verve, "Go make some money, girl."

I picked Emas up on my motorbike before arriving at these tracks so she could guide me from the street to the alleyways leading to her old haunts. I wondered what I would do if there was a police raid or a violent clash with religious extremist FPI thugs who are known for brandishing knives. They closed down a Lady Gaga concert, and they wouldn't think twice about taking down these ladies of the night. There was not enough light for my camera to capture images, and I did not want to hamper business for any of my friends. I decided to follow the breadcrumbs of vendor carts and passageways to get back to my bike and prepare for my return flight to the states in a matter of hours.

A piercing "D-a-v-i-i-d" rang out after a passing locomotive's air horn blew; everyone knows Emas's nasally register. This was the first night I had seen Emas in full make-up, wig, and mini-skirt; most of our interactions took place at the pesantren waria where t-shirts and shorts are the norm. A john was on her arm. "Daviid, wait twenty minute for me." She pointed to a semisecluded grassy field suggesting how these stomping grounds parlay into breeding grounds. "I'm 
leaving, Emas, and I fly out tomorrow." "No wait for me, Daviid, OK?" "I have a plane to catchhere, take this rupiah-l love you." "I love you too."

This vignette is one glimpse into the world of transgender Indonesians who live in the fourth most populated nation in the world with more Muslims than any other country. The international stage has developed a discourse of modernity and human rights related to sex and gender roles, while also communicating a discourse of repression related to Islam. This international narrative about rights and repression has put the Southeast Asian island nation of Indonesia in the spotlight. Additionally, in 2006, a team of experts met in Yogyakarta to create the Yogyakata Principles On the Application of International Human Rights Law in Relation to Sexual Orientation and Gender Identity. ${ }^{1}$ In the same year, Indonesia's oldest non-governmental organization, Planned Parenthood, began engaging with Yogyakarta's waria community to not only build their physical health, but their identity. This has created a hybrid of global, religious, and local discourses in the waria community.

This thesis summarizes an ethnographic study done in the city of Yogyakarta on the island of Java on the religiously oriented waria community. The waria are a transgendered community living on the island who take their name from the Indonesian words "wanita" (woman) and "pria" (man). The existence of this community highlights the tension between being Muslim within a global secular set of values that put the waria on the margins of both Indonesian society (for being a gender minority) and the LGBTQ community (for being devoutly religious). I will chart how this male-to-female waria community create spaces of belonging and security within a territory that has experienced geo-political insecurity: religious violence and natural disasters.

I argue that the waria see themselves as male, not men. Anatomy is not what gives the waria their gender, their feminine expression and sexual attraction is. Although the waria selfidentity as women/waria, in a religious context they perform as men, not women. Although the waria embody an identity that seems incongruent to most Westerns and Indonesians because of

\footnotetext{
1 Sonia Corrêa Withit Mantāphōn, "The Yogyakarta Principles Principles on the Application of International Human Rights Law in Relation to Sexual Orientation and Gender Identity" 2007, http://yogyakartaprinciples.org
} 
how gender has come to be constructed through religious, colonial, and post-colonial discourses, I contend that the waria are in fact a coherent identity through their own cultural logic. They simultaneously resist and replicate a gender binary through the mosque-like institution they have created called a pesantren waria. Furthermore, because the waria mark themselves as visible through feminine attire and body modifications, they make a claim on public space unlike the gay or lesbian Indonesian citizen. The warias' visibility pushes them into an identity politics that allows them to engage in national and religious discourses that the mostly unseen gay, lesbian, and bisexual citizen cannot participate in.

This study explores how the waria meet their needs for security and equality as citizens within the cultural hub of Yogyakarta, under the religious canopy of Islam, and in conjunction with being a citizen of the Indonesian archipelago. I interrogate how the waria have constructed their own canopies of social and religious legitimization. The male-to-female pious Muslim can seem like an object of ambiguity to both local Indonesian and international audiences raising questions about border transgression. How do waria respond to perceived transgressions and how do they make meaning as they work, live, play, pray, and perform in their private and public life? Although the waria perceive themselves to be a male-to-female transgender subjectivity, I will show how this subject position changes in a religious context.

Some of my primary research questions are: Do male-to-female transgender Indonesians, waria, in Java view themselves as a subject within the gender binary of "male" and "female" or outside of it? How do others outside this community perceive the waria's gender? How does religion influence this perception? What spaces have the waria created in their search for security and freedom to live in their unique embodiment?

\section{Methods and Theory}

To examine this issue, I conducted ethnographic fieldwork for almost three months in Yogyakarta which is home to a diverse variety of Islamic practices and gender/sexual identities. I studied at the Center for Religious and Cross-Cultural Studies (CRCS) at the University of Gadjah Mada (UGM) in Yogyakarta, the only program in Indonesia where students can study religion in a 
secular style setting. As a participant-observer I was immersed in the social milieu of the diverse cultural capital of Yogyakarta and connected with non-governmental organizations that dealt with gender and sexuality justice. Through personal relationships and trust, I made entry into the waria community and situated myself as an observer of how they encounter a variety of religious, political, and social worlds. After developing relationships with a sufficient number of informants, I began conducting interviews with Indonesians who were open to a recorded dialogue. I formally interviewed 40 Indonesians: 19 warias, 11 religious leaders, 4 academics, 3 non-governmental organization (NGO) leaders, 1 government minister, 1 gay male, and one family member of a waria. With empathy and analysis, I reflect on the discourses of personal life histories and larger social narratives within a religious, political, and globalized framework. All names of interviewees have been changed to preserve confidentiality.

The Indonesian archipelago was greatly influenced by traders who brought Islam in the 1200s from the Middle East and South Asia. ${ }^{2}$ The contemporary archipelago recognizes seven official religions: Islam, Hinduism, Buddhism, Catholicism, Protestantism, Confucianism, and Bahaism. Since almost 90 percent of Indonesians are Muslim and required to carry an identity card that states their gender and religion, an official national discourse is spread regarding what it takes to belong to a defined Indonesian citizenship. ${ }^{3}$

My work will look at how trans Muslim subjectivities in Java reconcile their religious ideas of ultimate order with their gender identity. Islam is a religious system that has traveled through various lands making its way into the American consciousness with images of "unbridgeable difference." ${ }^{4}$ When different worldviews are expressed by different communities and there is a

\footnotetext{
${ }^{2} \mathrm{P}$ Holt et al., The Cambridge History of Islam (Cambridge Eng: University Press, 1970).

${ }^{3}$ John Richard Bowen, Islam, Law, and Equality in Indonesia: An Anthropology of Public Reasoning (Cambridge, UK ; New York: Cambridge University Press, 2003).

${ }^{4}$ Tom Boellstorff, The Gay Archipelago: Sexuality and Nation in Indonesia (Princeton: Princeton University Press, 2005).
} 
conflict, Elizabeth Povinelli has labeled this "incommensurability." Tom Boellstorff has labeled this tension, as it relates to being both gay and Muslim, "ungrammatical." But I assert that the waria are a case study that goes against the grain of incommensurability and ungrammaticality. The waria draw upon theological and phenomenological tools that create an emic logic that holds together four elements of their gender assemblage: identity, expression, biology, and attraction. These four elements, though at times seem contradictory to a coherent gender identity of female or waria, how all my informants self-label, they are in fact commensurable. This commensurability is possible because of cultural and religious threads that tie the waria to a specific subjectivity.

Sexual selfhood is enacted in personal belief and in the public sphere. The expression of this selfhood is what I am studying since Indonesia is a Muslim majority country with strict ideas of order. Harmony and order are, according to psychologist Marshall Rosenberg, two of the deepest needs driving the actions of both religious and nonreligious people. ${ }^{6}$ I will examine how the waria of Indonesia make commensurable what many Indonesians find incommensurable: marginalized gender/sexual embodiments.

The present thesis is structured with chapter two framing the theoretical perspectives most employed by academics using Judith Butler, Judith Halberstam, Kate Bornstein, and Sandy Stone's conceptualizations of trans subject positions. Since I am arguing that the pious waria community is a unique male-to-female subjectivity that embraces a surprisingly fluid view of gender performativity, I will reference sociologist Sam Killerman's multi-spectrum model to elucidate the coherence and incoherence of a stable category of gender. In chapter three, I will present how the waria conceptualize their gender identity through the experience of key informants found inside the pesantren waria, a transgender space created by the waria to pray and learn. Chapter four focuses on how the waria negotiate the economics of survival, that is, living in a city where few employment opportunities are available and how the waria commercialize their body. Chapter five examines the ritual performativity in the pesantren waria,

\footnotetext{
${ }^{5}$ Elizabeth Povinelli, "Radical Worlds: The Anthropology of Incommensurability and Inconceivability," Annual Review of Anthropology 30 (2001), 319.

${ }^{6}$ Rosenberg, Nonviolent Communication, 2003.
} 
namely, how the waria pray and how they and religious leaders perceive themselves in a religious context. Chapter six will extend the horizon of ritual performance to look at the diversity of Islamic practice and thought. Finally, chapter seven will conclude with a synthesis of findings detailing how waria create their own cultural logic that is coherent with a model of gender that orbits around external components of anatomy and action along with internal components of gender identity and sexual orientation.

\section{Approach}

I employed a mixed-methods approach using both inductive and deductive logic. I analyzed a set of interviews inductively to find what words and themes emerge as areas of importance for my interlocutors, but I also deductively asked questions and examined how religious worlds shape my interlocutors realities. My aim was to discover explanations (emic and etic) for how and why the transgender waria perform their gender/sexual/and religious identity in various ways, in differing contexts. In a sense, I not only gathered, but created data in conjunction with my informants since I inquired about their gendered religious worlds while also listening to how they are linking information together. I searched out manifest and latent themes and meaning through content analysis where I quantified how many informants self-identify by gender and how these gender practices shift in varying contexts.

I consider myself a feminist in the sense that I desire equity for men, women, and all genders. I want to dismantle the obstacles that obstruct the road to full equity whether that obstacle is labeled patriarchy, matriarchy, monarchy, anarchy, or any other type of hierarchy. Like Puar, I take an assemblage-intersectionality approach that sees individuals as multiplicities, a concoction of ingredients that coalesce to make a form we might call an entity, while understanding that entity does not have any permanent ontology. ${ }^{7}$ I want to empower men who are more likely than women to be homeless, jailed, and non-degreed. I want to empower women who are more likely than men to earn less money, be elected to office, or be sexually abused. And I want to empower those genders that do not find a home in the category of man or woman.

\footnotetext{
${ }^{7}$ Jasbir K. Puar, Terrorist Assemblages: Homonationalism in Queer Times (Durham: Duke University Press, 2007).
} 


\section{Research Design}

Although my sampling of subjects were culled from the transgender pesantren in Yogyakarta (also known as Jogja), I still employed a chain-referral method of sampling because I suspected there were some pious waria that lived far enough away from the pesantren that made it difficult to attend regularly, or there may have been some that felt uncomfortable coming to the pesantren either because of interpersonal challenges or practicalities such as work schedules. My goal was to find key informants that could share broadly about the waria experience, but also to target specialized informants that could speak about living in a pesantren in their youth, or going to magicians to enhance their beauty, or Javanese Islamic practices. I employed unstructured and semi-structured interviewing with open-ended questions that covered life history in terms of coming of age as waria and religious identity and practice.

Participant observation was used as a strategic method as I took field notes, and video recorded the waria in their homes, places of work, and houses of worship. These became my qualitative data obtained through direct observation. I collected life histories, attended rituals, and although I picked up a few words and phrases in Indonesian, I was unable to become inconspicuous since I always had a translator next to me mediating my interactions. By spending two to four days a week at the pesantren over a 10 week period, I was able to reduce reactivity, that is, diminish how people change their behavior as a result of my presence. To quote anthropologist H. Russell Bernard, "Presence builds trust. Trust lowers reactivity. Lower reactivity means higher validity of data." I would like to think I succeeded in building that trust and validity.

My code of ethics included informed consent, do not harm, and the right of withdrawal. I did not see my informants as objects of study, but as partners in a conversation. In doing my research, I thought about three elements: epistemology, ontology, and methodology. I asked the questions: How do I know? What is the nature of what I know? How will I gain knowledge? My sympathies are in the Critical Theories camp that sees a multiplicity of interpretations possible around what is perceived to be reality. I chose to utilize ethnography to understand how the waria

\footnotetext{
${ }^{8}$ Bernarnd, Research Methods in Anthropology, 266.
} 
lived their daily lives, and I chose narrative inquiry to understand how the waria thought about their lives. By ethnography I mean that I observed, listened, documented, talked, and interacted with a community in their quotidian environment where they socialized, prayed, worked, and played. Clifford Geertz, in his book Interpretation of Cultures, coined the term "thick description" to describe when ethnography combines observation with interpretation. ${ }^{9} \mathrm{I}$ use this concept to describe a social and historical context around where I find the waria situated.

Through participant observation, I wanted to gain rapport with the waria community so I participated in their pesantren activities several times a week learning bits of Indonesian along the way. The pesantren waria is not just a social club, but an organization with a hierarchy that required me to learn how to negotiate the personalities and politics of any official group. Bonnie Brennen in Qualitative Research Methods for Media Studies groups participant observer researchers into four categories: "complete observer, observer as participant, participant as observer, and complete participant..10 Based on how Brennen describes these roles, I would situate myself in the "observer as participant" role since I was often on-site interviewing and interacting with interlocutors, but was not engaging in all rituals as a consequence of language barriers.

The histories you read are primarily taken from formal interviews, that were recorded with a video camera, transcribed into Bahasa Indonesia, translated into English, and interpreted through me. At each link in the chain there are a number of issues that usually go unreported such as what takes place during the interview, how I set it up, why I used a certain microphone, what facial expressions conveyed and how certain verbal communications will not make it to the final written manuscript. I am working with primary sources in a way that is co-creative because I'm not sitting in an archive, but engaging with a living being, and we may or may not like each other. Every piece of writing reveals and conceals, and I hope the reader is curious about that which is left unsaid. My identity as a white, thirty-something, gay, cisgendered, tall, American,

\footnotetext{
${ }^{9}$ Clifford Geertz, The Interpretation of Cultures: Selected Essays (New York: Basic Books, 1973).

${ }^{10}$ Bonnie Brennen, Qualitative Research Methods for Media Studies (New York: Routledge, 2012), 164.
} 
male, university student had an impact on the story being told. I like to think of myself as an advocate for the waria, for pushing what has been marginalized into the awareness of the mainstream with the intention of empowering the disadvantaged. I love interviews, particularly when I feel there is a spirit of collaboration between me and another subject. Out of the 40 informants I formally recorded, the relationship between us ranged from deep friendship to warm civility, to guarded curiosity, to skeptical regard, to perfunctory politeness, to partial disdain. When it serves the story, I incorporate my interlocuters' paralinguistic elements such as gesture and tone. Words on a page can appear flat and static, but appearances are deceiving, and I hope my attempt for accuracy also portrays the lively meanings the interviewees intended. Lynn Abrams, in her book Oral History Theory, notes the interview is a tripartite exchange: "The interviewee engages in a conversation with his or herself, with the interviewer and with culture."11 It is to this point that I explore the subjectivity of my informants through emic and etic categories as well as through the social context of Indonesian history.

I also make use of textual analysis with a mixed methods approach that integrates interpretive, narrative, performance analysis. With interpretive analysis I found meanings and interconnections throughout my informants interviews. In narrative analysis sought regularities or patterns that emerge within the interviews, that is, recurring structures that frame the data. I will conducted performance analysis on segments of the interviewees speech, that is, found patterns particularly within coming of age narratives that speak about how and when the waria knew they were in fact waria. Individual waria who are members of an Islamic transgender pesantren will be my primary unit of analysis; however, the waria's gender and religious identity and practices will be my secondary unit of analysis. Thirdly, I will analyze a range of community leaders to understand how gender and religion interact in the private and public sphere. I will then aggregate data on individual waria to make the collective waria community a fourth unit of analysis.

I conducted interviews where I asked open-ended questions related to the waria's life history, religious practice, and sexual and gender roles letting them determine their own

\footnotetext{
${ }^{11}$ Lynn Abrams, Oral History Theory (London: Routledge, 2010), 76.
} 
categories of identification. My instruments, or the questions I ask the waria, are inherently unstable since I am not asking quantitative questions. Although subjects can respond differently to the same question at different times, the questions will all revolve around gender identification, personal behavior, and social interaction in relation to presenting a transgender assemblage.

I call my approach enthographic because I did not only conduct in-depth interviews that were transcribed, translated, and coded, but because I relied heavily on participant observation inside the main location of my informants religious space: the pesantren waria or space for transgender male-to-female Indonesians that functions like a school, community center, and mosque at different times. This consisted of me attending "Sunday school"-the main day that the waria community gather at the pesantren to study the Quran, pray as a community, listen to a homily, and socialize over dinner. I also accompanied the waria to their homes, places of work, graveyards to honor the dead, and nonprofit organizations designed to prevent HIV and inform citizens about sexual health.

I designed a concept model to analyze the fundamental question: What is gender? Borrowing and modifying sociologist Sam Killermann's gender model, ${ }^{12}$ I interrogate four elements of gender to help clarify how the waria express themselves as masculine in certain contexts while still retaining a female/waria gender identity. I believe the gender schema on the following page helps clarify the unreliability of a binary model of male and female, and easily emphasizes the both/and logic of gender spectra (opposed to an either/or epistemology). This schema breaks gender into four elements: gender identity, gender expression, biological sex, and sexual attraction.

Based on the model I present, gender identity is how one thinks of themselves. Gender expression is how one acts based on gender norms of what is feminine and masculine. Biological sex is the anatomy one is born with. And sexual attraction is how much one desires any combination of the three previous elements. There are internal and external components to all of these elements. Assuming there are infinite ways a person can place themselves on these

${ }^{12}$ Sam Killermann, The Social Justice Advocate's Handbook: A Guide to Gender (Austin, TX: Impetus Books, 2013). 
eight spectrums, we can say there are infinite genders. Additionally, we can see these four elements as both an internal and external model. For example, let us take the element of "gender identity." One may think of themselves with one gender label (internal), yet others may view that same person with a different gender label (external). I found this true in Indonesia where a waria perceives herself as a woman, but someone in the neighborhood sees that same waria as a man. The same is true for "gender expression;" one may think their dress, demeanor, and interactions are masculine, but they can be read as feminine by an audience.

"Biological sex" has an external component by being visible: that which one can see with the eye. This mostly revolves around the presence of a penis/testes and vagina/ breasts. There are also other characteristics that are noticeable such as quantity of hair, voice register, shoulder and hip proportion, and physical stature. The internal component of "biological sex" would include that which is not visible: hormone levels, chromosomes, and internal organs such as ovaries or gonads.

Finally, "sexual attraction" can be the internal desire one has for a romantic/erotic/physical/emotional/spiritual connection with someone of a particular gender, or someone that expresses themselves in a certain way, or someone that possess a particular body. Although there can be attraction without it being sexual, I use the term "sexual attraction" because all of my informants spoke about this aspect of themselves in explicitly erotic terms. I employ the word "sexual orientation" interchangeably with "sexual attraction" because many of my informants did that spoke English. Although the terms "sexual orientation" is loaded with connotations of a modern, Western subjectivity connected to a discourse of human rights and the fight for marriage equality and equal rights in legal, military, economic, cultural, and religious realms, I use this term in its most neutral sense of directionality since "orientation" etymologically means "rise" (as in sunrise) or east. The external side of "sexual attraction" would be sexual conduct, or physical activity that is observable. 
Concept Map

Elements of a Waria Subjectivity
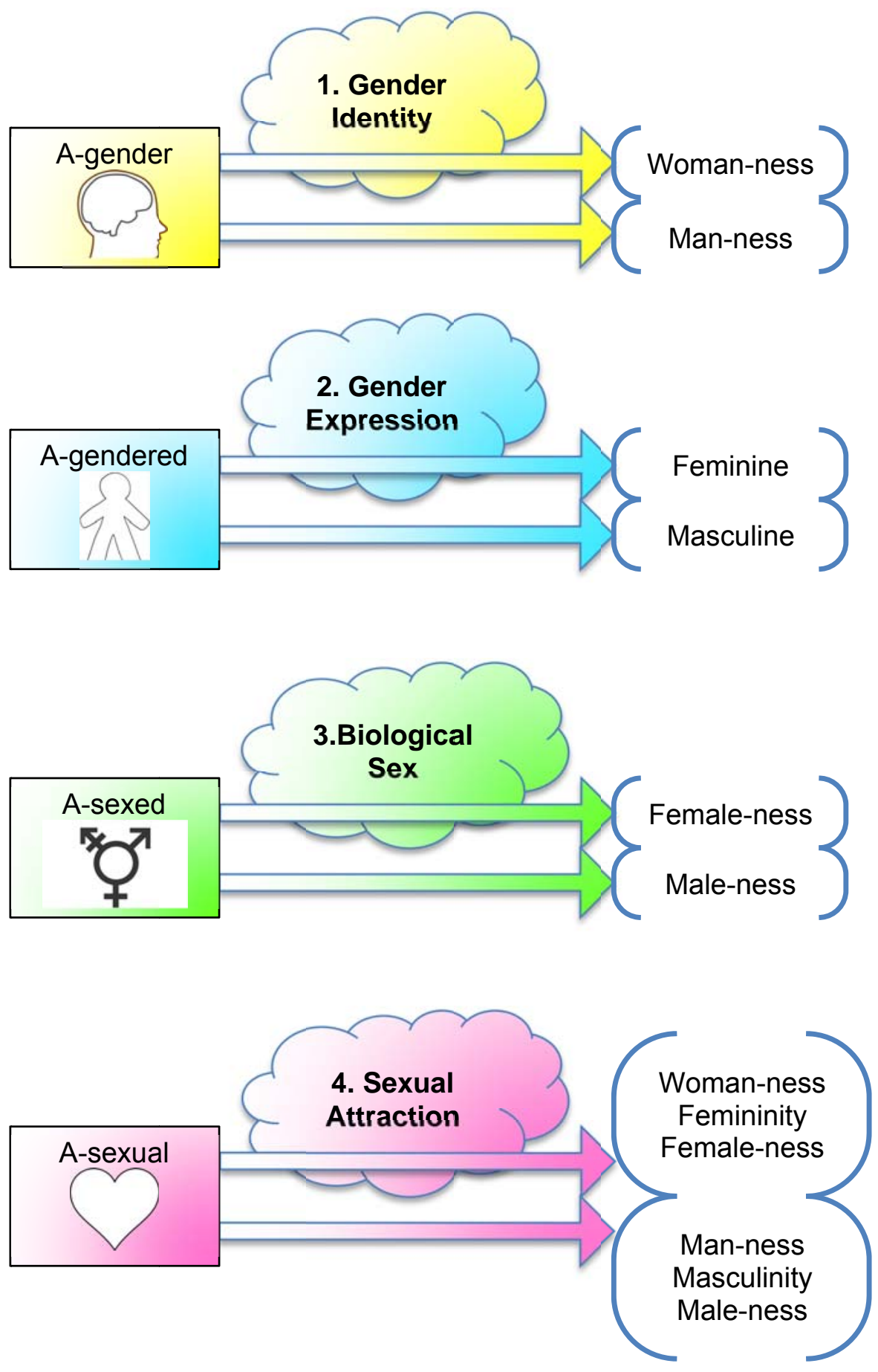


\section{Significance}

Scholarship in Indonesia often narrowly focuses on Muslim denominational conflicts or "third gender" anthropology. My research focuses a fundamental connection between religion, sexuality, and gender that creates a "third gender" unlike any other category. Academics and politicians often see a clash between liberal, globalized narratives of human secular rights against conservative, local Muslim narratives of religious duty. I suggest that the waria, through their ethnic, religious, and political expressions, have found a fundamental interconnectedness that transcends the clash of secular (rights) and sacred (duty). This research will contribute to filling a gap in gender studies and specifically male-to-female transgendered subjectivities within a religious Southeast Asian Islamic context. There is a dearth of information on the Javanese transgendered community because of their ambivalent social status and subcultural marginality. The present monograph will scrutinize an often ignored form of Islam in conjunction with transgender subjectivities in both local and national Indonesian spaces.

The significance of this study also rests on the fact that no other publication has examined the space of the pesantren waria. The word "pesantren" is an Indonesian word that translates as "residential school," or more literally as "a place for santri" or students. ${ }^{1}$ A pesantren is akin to a Hindu ashram or a Buddhist vihara in the sense it denotes a physical place for learning. A "pesantren waria" would literally mean a male-to-female transgender (waria) boarding school (pesantran). However, when I employ the words "pesantren waria," I am using the term the way my informants use it: a safe, spiritual space where transgender citizens can worship Allah and learn the scriptures in accordance with Islamic sharia, not necessarly a boarding school. In Indonesia, pesantrens are also commonly called pondok pesantrens where pondok can be translated as cottage or hut, so a "pondok pesantren waria" is a home where transgender Muslims come to learn about Islam. In common parlance, "pondok pesantren" is abbreviated to "ponpes" and I will do the same throughout this manuscript. At times I refer to the ponpes as a mosque (masjid) because its function is closer to what a Western audience would think a

1 Bianca Smith and Mark Woodward eds, Gender and Power in Indonesian Islam: Leaders, Feminists, Sufis and Pesantren Selves (New York: Routledge, 2014), 4. 
mosque's pupose is: to temporarily house the faithful to perform rituals and listen to teachings. The waria themselves were unsure of what to name the space they created in 2006 to freely pray in, and they decided, for political and financial reasons, to settle on the title "pondok pesantren waria" even though the space is not a full-time dedicated school staffed with teachers and students to impart religious and secular education and award diplomas as would be the case with most ponpes. The pesantren waria is the living room and porch of one waria's large house where the community gathers on Sundays (and Wednesdays during Ramadan) to pray, learn Arabic, recite the Koran, listen to sermons, and socialize with friends over dinner. 


\section{CHAPTER TWO: LITERATURE REVIEW}

In this chapter, I explore how the literature related to trans subject positions challenges what we think of as human, and interrogate the most common two categories Indonesia and the U.S. divides humans into: male and female. Although most Indonesians and scholars conceptualize gender as stable, this chapter argues for a conceptualization based on assemblage and a multiplicity of gender elements that can be configured and reconfigured ad infinitum.

The term "transgender" is sometimes used as an umbrella terms that can mean any person outside the single category of 100 percent man/ masculine/ male, and any person not fitting perfectly into the single category of 100 percent woman/ feminine/ female. I use this term the way my informants use it, to mean someone that has a gender identity other than one assigned to them at birth, regardless of their born biology or anatomical modification. There has been some writing on the subject that has adopted the neologism "trans"," pronounced "transstar," to denote a plethora of identities, much like an asterisk in Boolean computing terms denotes a wildcard, but for clarity's sake I am using transgender in it's Indonesian sense. Although most waria between the ages of 40 and 60 have undergone some type of bodily modification beyond applying facial cosmetics, I do not use the term "transsexual" since it places attention on biological anatomy and not on the relevant issue of gender in its amorphous totality consisting of a relationship between: identity, expression, biological sex, and romantic and sexual attraction. In other words, in an Indonesian context, gender is an assemblage that incorporates the brain (identity), the body's behavior (expression), the body's physiology (sex), and the attractions one has to these three elements (sexual orientation).

Viviane Namaste in her book Invisible Lives points out the relationship between trans identities and prostitution. She writes, "transexual lives are ordered, governed, and controlled in and through the criminalization of prostitution."1 Most of my waria interviewees are sex workers, and they order their lives around when they can and cannot serve clients, whether that be under

\footnotetext{
${ }^{1}$ Viviane K. Namaste, Invisible Lives: The Erasure of Transsexual and Transgendered People (Chicago: University of Chicago Press, 2000), 27.
} 
the shadow of nightfall, in a public space or deserted field, or during a religious holiday when some police decide to enforce anti-prostitution laws. I am in agreement with Patricia Elliot, author of Debates in Transgender, Queer, and Feminist Theory, when she writes that it is important for non-trans persons to end violence to gender diversity, not just admonish, but end ongoing violence. She suggests we embrace "transpersons' demands for recognition" and concern ourselves with "how power circulates in the meaning, experience, and performance of gendered bodies." ${ }^{2}$

As a gay man that mostly aligns my gender expression in masculinity, my gender identity in manness, and biological sex in maleness, to use a multiple spectrum model, I am nonnormative in one category: sexual orientation. Living with the waria has made me cognizant that there are those that are more vulnerable due to different embodiments. Analysis and synthesis are hallmarks of scholarly inquiry, and when these cognitive moves come to bear on trans populations, be they transvestite, transgender, or transsexual, it is important to know the context of oppression such populations live under. As Judith Butler suggests, in Undoing Gender, scholarship has "consequences for how gender presentations are criminalized and pathologized." Butler writes that those involved in gender politics need to scrutinize their "presumptions about bodily dimorphism, the uses and abuses of technology, and the contested status of the human, and of life itself." ${ }^{4}$ This is a call to not only examine various labels around gender, but to look at how body modification influences our perceptions of what is acceptable and what is not. After spending time in Indonesia, where silicone injections and hormone pills are popular among the waria, my notion of gender has broadened to include such practices. If we are to problematize the question of who is a man, woman, or other gender, then we are asking what comprises such a category and who gets to be in it. In other words, who gets to be, as articulated

\footnotetext{
${ }^{2}$ Patricia Elliot, Debates in Transgender, Queer, and Feminist Theory: Contested Sites (Burlington, VT: Ashgate Pub, 2010), 8.

${ }^{3}$ Judith Butler, Undoing Gender (New York: Routledge, 2004), 30.

${ }^{4}$ Ibid., 11.
} 
through speech and behavior, a woman? To question the pieces that make up womanhood is to orbit around the concept of what is legitimate and what are the boundaries around inclusivity.

Gender as a World of Meaning

Elliot encapsulates the complexity of what defines a woman when she says,

"Transsexuals pose a challenge, intentionally or not, to mainstream feminist conceptions of sex as a stable and immutable basis of gender, a challenge which raises questions about presumed 'authenticity' of identity and about the inclusiveness of feminist politics." ${ }^{5}$ Identity politics relies on stable categories, as does communication if it is to be intelligible. Though such categories are useful for garnering support for political causes, it conceals other configurations of gender identity/gender expression/biological sex/sexual orientation that are possible.

On the other hand, Kate Bornstein, in her book Gender Outlaw, lays out an argument promulgating that any individual can choose how to identify and thus become a gender they specify. Realizing Bornstein's thesis comes out of a Western framework of singular persons claiming rights or an identity versus a collective that bestows status by agreement, I am not sure how to get beyond the question of what gender one is except by accepting an individual's enunciated status. To ask what one is to reduce people to static objects. The waria, like all trans people, need healthcare, education, housing, gainful employment, safety; these issues are not part of a conversation that asks what you are. To meet the basic needs of trans people, the question must transform from what to how.

Transexual and transgender epithets create different worlds of meaning for different people. Common discourses around transsexual identity often include phrases as "in the wrong body" or "passing as a man or woman" which presupposes a set of expectations of what gender is or should be. For this reason, Bornstein sees transexuality as not radical, but as reinforcing the gender binary; whereas Sandy Stone, in the book Body Guards, sees transsexuals "as a genre-

\footnotetext{
${ }^{5}$ Elliot, Debates in Transgender, Queer, and Feminist Theory: Contested Sites, 21.
} 
a set of embodied texts whose potential for productive disruption" can be tapped into. ${ }^{6}$ I want to steer away from diagnosing levels of transgression and look at the textuality of the word "gender" which comes to us through Latin from the word "genus" which can be translated as "kind/order." In compositional theory, genre is part of what makes up the rhetorical triangle: genre, audience, and purpose of the writer. It is helpful to illustrate the contextuality of gender by thinking in these rhetorical terms. If a person wants to present themselves as a gender (assuming there are more than the binary allows), they can do so for themselves; however, there is always an audience since we live in a relational world. There is an audience with a set of expectations that arise from social norms, and depending on our purpose, we may or may not want to persuade an audience of how well we align with gender roles.

There is debate among trans theorists between those that think it is efficacious to identify as man or woman and not be "dilettantes and recreationalists in the game of gender" that see more value in transgender as a more transgressive or queer understanding of gender norms. Namaste, in Sex Change, Social Change, sees a transsexual agenda pitted against a transgender agenda where "transsexuals do not make sense of their lives in lesbian/gay terms" while transgenders do. ${ }^{8}$ The separation of transgender/transsexual is blurred in the context of the waria for physical and psychological reasons. Every waria I asked self-identified as female or waria in gender identity and expression, thus they perceived themselves as heterosexual, disregarding their male biological sex as a criterion for gender identity. Nonetheless, when speaking about their religious world, the waria expressed themselves as masculine while still retaining a waria gender identity. The word transgender in America connotes a critique of the gender binary where transsexual may not, whereas transgender/transexual (waria) categories in Indonesia do not carry the same social and political antagonism.

\footnotetext{
${ }^{6}$ Julia Epstein and Kristina Straub, Body Guards: The Cultural Politics of Gender Ambiguity (New York: Routledge, 1991), 296.

${ }^{7}$ Judith Halberstam, Female Masculinity (Durham N.C.: Duke University Press, 1998), 167.

${ }^{8}$ Viviane K. Namaste, "Sex Change, Social Change Reflections on Identity, Institutions, and Imperialism," Women's Press, 4.
} 
A discourse among scholars implies that to be high queer is to be the most radical, and the most radical is to abandon the social expectation to align biological sex with gender identity, expression, and heteronormative sexual/romantic attraction. This notion creates a hierarchy of identities, for Bornstein, if transgender denotes such non-alignment and transsexual denotes conservative, historically constructed identities. Namaste brings such conceptualizations back to a grounded reality by asking questions that revolve around practicalities and power such as when asking, "Would someone please tell me how to get an apartment when one is neither a man nor a woman? Where does one find a physician to treat neither man nor women?" ${ }^{\prime 9}$ These inquiries reveal exactly why waria are not discussing their maleness or womaness or taking on an idealization of gender incongruence under an identity of queer; they are already marked as visibly different and are using all their agency to find housing, health, and happiness.

\section{Gender Congruence}

The label "queer" means different things to different people. Halberstam suggests that such a term can be used for anyone who sees gender as a nonfixed construction and could include heterosexuals. Namaste sees queer as outside a male and female category with visible transgressions of societal expectations. The former reading can include transsexuals under the umbrella of queer while the latter reading would exclude such a community. Namaste writes that transgender theory can cause "erasure and contempt for transsexual people."10 This viewpoint sees transgender theory as downplaying the transsexual communities actions to gain gender congruence and live out their lives as men or women.

Transgender theorist writers such as Sandy Stone, Kate Bornstein, Judith Halberstam, and Judith Butler valorize ambiguousness, unstable identities, and non-passing and illegible expressions of gender and sexuality. The waria, though calling themselves transgender, are closer to wanting the opposite of what is valorized by such writers, that is, closer to the Western notion of "transsexual." Looking at Butler's analysis of gender identity disorder as a tool of

\footnotetext{
${ }^{9}$ Ibid., 22.

${ }^{10}$ Namaste, Invisible Lives, 24.
} 
diagnosis in her chapter "Undiagnosing Gender," we see her argue that such a diagnosis easily leads to a subjection to norms which Butler does not support. To be fair, Butler is not opposing a transsexual identity that clearly marks people as man or woman, but she is questioning it. She writes, "It would be wrong to call for its [gender identity disorder's] eradication without first putting into place a set of structures through which transitioning can be paid for and legal status attained."11

Henry Rubin, in his book Self-made Men, points out the contributions the transsexual community has made in the medical complex in developing technologies such as "hormone replacement therapy, in lobbying for access to sex reassignment surgery in the US, and in founding and funding gender clinics ..."12 Speaking about the medical complex, Butler contends that some trans people will be negatively affected psychologically as long as a disorder is articulated by the medical establishment through the Diagnostic and Statistical Tigaal of Mental Disorders (DSM), particularly related to queer and trans youth. What is at issue, for Butler, is the notion of resisting conformity or undercutting "transautonomy." Butler asserts that gender identity disorder "assumes that certain gender norms have not been properly embodied, and that an error and failure have taken place ..."13 Although it seems that a diagnosis can harm individuals, I wonder about those trans people that in fact voice that an error has taken place and they would like medical help in fixing such a condition. Where Butler would like to undiagnose gender, the waria would like to more firmly establish theirs. Even if gender is ultimately a moving target, the transsexual or male-bodied female in Indonesia want to capture it. The waria want their neighbors to see a them as a stable category of gender, that is, as waria, so they are not accused of being sinful homosexuals as a popular strain of Islam submits, and so they can be seen and heard for the subject position they wish to be.

\footnotetext{
${ }^{11}$ Butler, Undoing Gender, 82.

${ }^{12}$ Henry Rubin, Self-made Men: Identity and Embodiment among Transsexual Men, 1st ed. (Nashville, TN: Vanderbilt University Press, 2003), 76.

${ }^{13}$ Butler, Undoing Gender, 77.
} 
Elliot sees Halberstam as bridging two communities: "lesbian feminists (who see Ftms as betraying feminism) and transsexuals (who see butches as failed transsexuals).. ${ }^{14}$ Halberstam says there is a "queer hybridity" that allows people to live without a coherent gender. She continues in her book In a Queer Time and Place to say "transsexual is not simply the conservative medical term to transgender's transgressive vernacular; instead, both transexuality and transgenderism shift and change in meaning as well as application in relation to each other rather than in relation to a hegemonic medical discourse." 15

"Possibility is a necessity,"16 says Butler in regards to those who fall outside nonnormative gender embodiments. Non-normative is a challenge to normative in the sense that the normative cannot understand or make intelligible what falls outside its boundaries. The waria seek to be understood as women or a type of women that may be called a third gender in contrast to Tom Boellstorff's hypothesis that the waria are a subcategory of male. ${ }^{17}$ To call the waria a type of male is to privilege biological sex over the other three elements that the waria see as giving them gender: a waria identity, feminine mannerisms and presentation, and the waria's sexual attraction to men which bolsters their sense of waria gender (unless the West which distinguished between sexual orientation and gender identity. Butler argues that the boundaries of human need to be enlarged to include many forms of gendering. In contrast to this, Bornstein lays out an "outlaw" position where trans identities are not assimilated, but highlighted as different from the norm. If Bornstein wants to maintain an unintelligible subject position and Butler want to move the unintelligible to the intelligible, I wonder if both claims can be held simultaneously. Elliot argues that transgender people are both intelligible as subject positions and unintelligible as contesting normative subject positions "in ways that are informative for any critique of gender,

\footnotetext{
${ }^{14}$ Halberstam, Female Masculinity, 48.

${ }^{15}$ Judith Halberstam, In a Queer Time and Place: Transgender Bodies, Subcultural Lives (New York: New York University Press, 2005), 54.

${ }^{16}$ Butler, Undoing Gender, 41.

${ }^{17}$ Tom Boellstorff, A Coincidence of Desires: Anthropology, Queer Studies, Indonesia (Durham: Duke University Press, 2007).
} 
sexuality, and embodiment." ${ }^{18}$ If we see transgender as embodying the incoherent and ambiguous, and transsexual as embodying the coherent and aligned, how do we create a sense of belonging for all bodies?

\section{Implicit and Explicit Gender}

Any angle of vision will simultaneously reveal and conceal, will highlight and shadow, and so it is as we gaze at gender. Butler, in Bodies that Matter, points out what can be gained and lost in articulating an identity when she says a person can produce "its coherence at the cost of its own complexity, the crossings of identifications of which it is itself composed ..."19 Butler guides us to reflect on what is left outside when we reduce ourselves to labels. Elliot references Butler's vision here when she proposes pursuing a "project of legitimizing complexity." ${ }^{20}$ Basic values of respect, recognition, safety, belonging, and compassion are not so complicated, but extending such values to those whose bodies are visibly different can be challenging. John Waters would film his leading protagonist, Divine, simply walking down a main street in Baltimore, Maryland in punk drag to capture the responses of pedestrians nearby. Folks suddenly confronted with a body in a colorful frock and shaved hairline that allowed for exaggerated makeup could not read Divine as an intelligible human that fit into categories of man or women, straight or gay, safe or dangerous. People would laugh, scream, stare, cringe, or stand perplexed at the queerness in front of their eyes. It is challenging to extend basic values of respect to unconventional modes of being, especially when assumptions about identity are being undone, or when assumptions about "who counts as human" ${ }^{11}$ are being undone.

Elliot sees legitimizing complexity as a strategy for making the normative a subject of debate and mentions Biddy Martin's chapter "Sexualities Without Genders and other Queer

\footnotetext{
${ }^{18}$ Elliot, Debates in Transgender, Queer, and Feminist Theory, 63.

19 Judith Butler, Bodies that Matter on the Discursive Limits of "Sex" (New York: Routledge, 2011), 115.

${ }^{20}$ Elliot, Debates in Transgender, Queer, and Feminist Theory, 72.

${ }^{21}$ Butler, Undoing Gender, 28.
} 
Utopias" published in the journal Diacritics, to bring awareness to the fact that all gender identities are an assemblage of multiplicities and that any unity is a fiction. The notion of intelligibility is also fictive because of such complexity, and referring to intelligibility gives norms power. ${ }^{22}$ The assumptions these authors are asking to be problematized are: gender is binary, gender is immutable, and bodies must be members of one category. To wallow in complexity, as Management Professor Kimbrough Sherman puts it, is to wrestle and examine issues deeply. ${ }^{23}$ Instead of marginalizing those that have failed to secure a coherent gender identity, can we extend recognition, belonging, safety, and respect to complex embodiments that might challenge what we think of as normatively human? I affirm we can wallow in complexity and simultaneously roll in the beauty of understanding, even empathy.

Speaking directly about a multiplicity of assemblages, Jasbir Puar in her book Terrorist Assemblages: Homonationalism in Queer Times, eschews the word "identity" to talk about "assemblages" to highlight a subject's intersectionality and complexity (not incommensurability). Assemblage, for Puar, undermines a coherent identity. Identity presumes that components such as religion, gender, race can be separated from a person and that by naming these separate categories there is a stabilization across time that is actually fictive. "We can think of intersectionality as a hermeneutic of positionality that seeks to account for locality, specificity, placement, junctions." ${ }^{24}$ Furthermore, Puar avers the term queer "assemblage" or "intersectionality" is a more effective term to use instead of a queer "identity" because the word assemblage or intersectionality highlights convergences and "deprivileges a binary opposition between queer and not-queer subjects." 25

\footnotetext{
${ }^{22}$ Elliot, Debates in Transgender, Queer, and Feminist Theory, 73.

${ }^{23}$ John D. Ramage, John C. Bean and June Johnson, The Allyn \& Bacon Guide to Writing, 4th ed. (New York: Learning Solutions, 2010), 27.

${ }^{24}$ Puar, Terrorist Assemblages, 212.

25 Ibid., 205.
} 
Transgender persons (as well as transsexuals) challenge a certainty that there is a natural link between biological sex and gender identity (how we think of ourselves) and gender expression (how we act based on perceived gender roles). This "coincidence of sex and gender" can be broken apart to upset the "hegemonic gender order." ${ }^{26}$ Psychologist and author Marshall Rosenberg once told me to never give someone the power to make me submit or rebel. I understood him to mean never view another persons' words to be a demand, but rather a request of what they would like, regardless of the words they use to make that request, and to choose my behavior based on shared values between two humans. His words can also apply to transgender theory in the sense that a person will be less aware of their power if they believe they have to embody a norm or refuse a norm (perhaps like transsexual $v$ transgender); rather, it is possible to have a deep understanding of self, others, cultures, as not made up of illusionary norms that are fixed that tell people what they are (male, female, intersex, asexual, demisexual), but as an assemblage of values and desires that can take different forms at different times in different places.

Elliot theorizes that those that think unintelligible subjectivities are more radical and call for greater possibilities for what is human, may want to self-reflect because such thinking may just be a "reversal of the hierarchy to effect a welcome valorization of some delegitimized trans groups." ${ }^{27}$ If we trick ourselves into thinking there is such a thing as "man" or "woman" or a coherent gender, then we will also trick ourselves into believing there exists an incoherent gender or "transman" or "transwoman." I suggest that any noun we use to describe ourselves will be a fiction and will create insider and outsider categories. I see a way beyond hierarchical structures through transforming our thinking from what someone is to how someone is because we are all incongruent.

Trans embodiment speaks to psychological, biological, and social realities. Transexual and transgender people, by their existence, question the sex/gender alignment and to varying

${ }^{26}$ Elliot, Debates in Transgender, Queer, and Feminist Theory, 79.

${ }^{27}$ Ibid., 81. 
degrees contest or affirm it. Bauman makes a compelling case that human is a leaky category, ${ }^{28}$ and yet there is a particular stigmatization that trans subject positions experience. Elliot asks the question, "To what extent do differences in degree become differences in kind?" ${ }^{29}$ In other words, the question is how similar and how different are cisgender persons to transgender persons? How similar and different are transgender persons from transsexual persons? The waria seek the freedom to become more fully female in gender (although this is complicated by their religious observances when their gender expression is temporarily performed as masculine). None of my waria interviewees expressed a desire to dismantle gender, or even contest or affirm it, only to expand it.

\section{Contexualized Gender}

I suggest we need other theoretical tools to understand the specificity of the waria-maleto-mostly-female experience, especially as it relates to gender expression in a ritual context. Respect for others includes recognizing what is similar and different from our own experiences. If the term transsexual implies sex reassignment surgery and transgender does not, what are we to make of communities like the waria that overwhelmingly do not have surgery but may take hormones, or inject silicone into their bodies to be perceived as more feminine? Depending on one's perspective, the waria can be seen as either refusing gender norms or complying with such norms. In a sense, the waria are in-between transsexual and transgender, and yet they do not refuse gender norms; they just do not inhabit the norms that are ascribed to them at birth as men.

If trans identities are an invitation to learn how to count beyond two, I think it is possible to go beyond binaries in theory as well. The clichéd dichotomy of nature versus nurture, where biological determinism (nature) accounts for much of our lives beyond our control, is actually quite similar to a social matrix with discursive boundaries (nurture) that is largely beyond our control unless one has a saintly capacity for awareness and patience to act differently from the norm. The question is not: is gender formed by either nature or nurture? but what complexities of

\footnotetext{
${ }^{28}$ Whitney Bauman, Religion and Ecology: Developing a Planetary Ethic (New York: Columbia University Press, 2014).

${ }^{29}$ Elliot, Debates in Transgender, Queer, and Feminist Theory, 89.
} 
physiology and physicality assemble into what we call human? Elliot cautions us to not confuse the "uncommon with the nonhuman (transsexual as monstrous 'other'), or ignoring important distinctions because one is eager to embrace otherness as sameness. ${ }^{30}$ I see her as warning us to not associate what is not typical in most of the population with what is diagnosed as pathological while also suggesting we not make a diagnosis of normal into sameness.

There is a psychoanalytical aspect of embodiment that Elliot touches on that I see as meaningful. She writes, "the social construction of gender (that is, the historical and cultural production of meanings attached to men and women) shapes but does not determine how one inhabits or fails to inhabit a sex." 31 The distinction between what "shapes" gender and what "determines" gender is key. We can break apart many influences that contribute to an identity we call gender, but to come to a more direct determination or cause of what makes gender will prove to be elusive since, in my view, gender is a strategy employed (consciously and unconsciously) to meet needs for recognition, visibility, belonging, and sexual expression. Elliot goes on to make the same distinction on the material level when she writes, "that the organism (the physiological, biological or hormonal aspects of a person) participates in, but does not determine how a subject negotiates the processes of embodiment." ${ }^{32}$ We are dealing with a complex negotiation of processes that make up a person, and I propose that dealing with the values I just mentioned is one method to go beyond binaries of nature versus nurture, that is, dealing with human needs/values is a move away from what someone is to how someone is.

Many scientists are studying trans subjects to determine if there is a biological basis for the identity and behavior. Akin to the search for the physiological cause of homosexuality, neurologists and biologists have purported "to have located a protein in the Mtf brain that resembles similar protein in non-trans women's brain." ${ }^{33}$ The tendency to privilege this type of

\footnotetext{
30 lbid., 103.

${ }^{31}$ Ibid.,104.

32 Ibid.

${ }^{33}$ Ibid.,116.
} 
science is welcomed by me if it translates into wider political gains for gender/sexual minority groups, but the veracity of such claims is up in the air. Gary Kinsman, in the book Making Normal, delineates four reasons why an argument for acceptance based on biology is problematic. To paraphrase, firstly, if most humans are born with a typical set of internal and external attributes, anything atypical can be seen as a biological error and invasive corrections can take place or even genetic engineering. Secondly, when such atypicality is seen as impure, then murder or abortion can be seen as legitimate practices such as the Nazi's employed against LGBT persons. Thirdly, it can cement the notion of rights that come from biological diversity as opposed to rights that are respected based on choices. Lastly, a biological determinism precludes displacement of a heterosexist hierarchy, but establishes ones place within it. $^{34}$

Male and female are evaluations, not observations to borrow Marshall Rosenberg's distinction of how phenomena are perceived by the human brain. ${ }^{35}$ One can talk about what they see in terms of genitalia, body shape, hair, and organs, but to go beyond description is to create meaning or evaluation, a secondary process of which most are not conscious. We can speak of male and female, but with the understanding that these are made up evaluations, and that we further make up the notion that they are permanent or stable categories. This does not mean that there are not differences between bodies; it means we determine what those differences mean. Roger Lancaster, in his book The Trouble with Nature, writes "nothing in the distinction between male and female dictates how many other sexes might be discriminated, what their roles and relations might be, or what meanings might be said to follow from these distinctions and relations." ${ }^{\text {36 }}$ This may mean that the dual complementarity of opposite sexes is fictive and locks us into a binary logic. Naturalized desire and gender, that is, categories that are seen as arising

34 Deborah R. Brock, Making Normal: Social Regulation in Canada (Toronto: Nelson Thomson Learning, 2003), 277-283.

${ }^{35}$ Marshall B. Rosenberg, Nonviolent Communication: A Language of Life, 2nd ed. (Encinitas, CA: PuddleDancer Press, 2003).

${ }^{36}$ Roger N. Lancaster, The Trouble with Nature: Sex in Science and Popular Culture (Berkeley: University of California Press, 2003), 226. 
from the genetic substrate of the planet does not take into account the diachronic aspect of gender and sexuality. Put simply: people change.

Social discourses around "normal" and medical discourses around "nature" can be employed in different ways. A genetic argument for sexual and gender minorities may circumvent normalizing a gender binary; however, "born this way" theories may also lead to perceptions of "biological error," as therapist and radio show personality Dr. Laura Schlesinger articulated on her syndicated radio talk show. Inappropriate medical interventions can be justified by perceived error as has been the case with infant intersex surgeries.

\section{Beyond Binaries}

David Reimer, who committed suicide in 2004 , is a case where the discourse of nature versus nurture played out tragically. As Butler describes the case in Undoing Gender, Dr. Money was determined to prove that gender could be culturally inscribed onto an infant when he supported raising David as a girl after his genitals were inadvertently burnt off during a circumcision. This cultural determinism is in stark contrast to biological determinism that seemed to overrule the former since David never accepted his female status and chose to live his adult life as a male. Elliot thinks that a psychological perspective transcends the nature/nurture dichotomy that says an inborn gender identity or a socialization process creates a gender identity. Using psychoanalytics, Elliot sees the genetic body working in conjunction with the biological brain that has complex unconscious and conscious processes that create desires, emotions, and identities. ${ }^{37}$ John Colapinto in his book As Nature Made Him pieces together David Reimer's life history. What is striking to me, and buttresses Butler's work about the power of discourse, is when David, who had been known as Brenda for twelve years, asks, "What . . was my name?"38

\footnotetext{
${ }^{37}$ Elliot, Debates in Transgender, Queer, and Feminist Theory, 138.

${ }^{38}$ John Colapinto, As Nature Made Him: The Boy Who Was Raised As A Girl, 1st ed. (New York: HarperCollins Publishers, 2000), 180.
} 
As Elliot puts it, David wanted to know "the hidden truth that he had once been called something else, that his original, proper name signified a masculine subject." ${ }^{39}$

There are contested theories around the etiology of sexual and gender diversity with biological, sociological, and psychological dimensions. Sam Killermann, in his book The Social Justice Advocate's Handbook, sees gender as made up of four elements: identity, expression, biological sex, and sexual/romantic attraction. The way these dimensions interrelate make up the complex realities of gender subjectivity. Killermann emphasizes that all four aspects of gender relate to each other, but are independent of each other. As I return later to examine the complex gender identity of the waria of Indonesia, I will employ Killermann's independent-unidirectionallinear-continua model shown in graphic form at the end of the previous chapter. Killermann speaks about gender as if it is a comestible, connoting that many ingredients assemble to create something edible, like many elements assemble to make up what we call gender. As I slice up reality in an academic move to better theorize and understand gender and sexual embodiment, I come back to my original intention of understanding what is counted as human.

I cannot concur with anthropologist Tom Boellstorff in his analysis that the waria are a subtype of men because it goes against the ethics of giving individuals the agency and recognition they request, not to mention the privileging of biological sex over expression, attraction, and identity. Every waria I spoke to recognized they were male in biological sex; however, all of my informants identified as waria or female, not male, and discounted their biological sex except in a ritualized religious contexts. Boellstorff's thesis that the "waria are not a 'third gender' but a male femininity ... [and] operates within the orbit of male gendering" ${ }^{\prime 0}$ is to demote the waria's own perception of themselves as waria/women and to valorize the dominant discourse of Salafi Muslims and the nation-state that sees them as feminine men. Eve Sedgwick, in her book Epistemology of the Closet, lists different sexual/gendered forms subjects can think in

\footnotetext{
${ }^{39}$ Elliot, Debates in Transgender, Queer, and Feminist Theory, 145.

${ }^{40}$ Tom Boellstorff, "Playing Back the Nation: Waria , Indonesian Transvestites," Cultural Anthropology 19, no. $2(05,2004) 161$.
} 
and experience,$^{41}$ and there is growing awareness that there are multiplicities of identities.

Facebook now has over 50 different genders one can click on to create an online gender identity, and with over a billion Facebook users, 63 million of which are in Indonesia ${ }^{42}$, a global discourse about gender is being formed. There is widespread awareness that differences can stand on their own and not be collapsed into frameworks of male and female. Positions of either/or create binaries of man/women, nature/nurture, and extend into our evaluative thinking of good/bad or right/wrong which closes out more nuanced conversations and subjectivities that don't fit into such binaries.

Jasbir Puar calls the national recognition, in the West, that is given to a limited type of sexual subject "homonationalism." She writes, in Terrorist Assemblages, that what is of note is "that an exceptional form of national heteronormativity is now joined by an exceptional form of national homonormativity, in other words, homonationalism.." ${ }^{43}$ Homonationalism critiques the "valorizing of life" 44 which seems odd at first blush to propose a critique of what seems selfevident: life is of value. But we know life by knowing death, so homonationalism speaks to how we come to know binaries of not only life and death, but security and insecurity, wealth and poverty. Puar describes a transition that is happening where sexual/ gender minorities' relationship to the nation is shifting from one of death to one of life. This is most clearly seen in the US where gay men were figures of death because of AIDS/HIV and now same-sex marriage and adoption are quotidian issues in the media that orbit around notions of life and reproduction. Puar avers that if there is a queer subject folded into a "politics of recognition," ${ }^{45}$ then there is also

\footnotetext{
${ }^{41}$ Eve Kosofsky Sedgwick, Epistemology of the Closet (Berkeley: University of California Press, 1990), 25.

42 "Facebook Users in Indonesia Have Highest User Usage Rate Worldwide: Indonesia is Home to the Third Largest Facebook Mobile Phone Audience," eMarketer, published January 22, 2015, accessed March 22, 2015, http://www.emarketer.com/Article/Facebook-Users-Indonesia-HaveHighest-Mobile-Usage-Rate-Worldwide/1011896.

${ }^{43}$ Puar, Terrorist Assemblages, 2.

${ }^{44}$ Ibid., xi.

${ }^{45}$ Ibid., xii.
} 
queer bodies that are marked for dying. I suggest that because Indonesia is a heteronormative state and among the most progressive politicis

The Unites States sutured heterosexuality with reproduction and consumerism in the ideal conception of a national subject. With the abatement of AIDS and a gay community without children, the disposable income of the gay community was sought after by marketers beginning in the 1990s. American exceptionalism has carried over, for Puar, to gender exceptionalism where American women incorporated a "missionary discourse to rescue Muslim women form their oppressive male counterparts.." ${ }^{46}$ Thus, the queer Muslim can be jarring for a Westerner since they can be "doubly indicted for the fundamentalist religion they adhere to or escape from and for the terrorist bodies that religion produces." ${ }^{47}$ Although most waria in Yogyakarta are not part of a an official pious community or even participate in Islamic rituals outside of cultural holiday gatherings, the more secular waria do not see the pesantren as a space of repression or lack of agency.

The pesantren waria is visited by journalists and scholars every day because it is surprising in how it negates a secular human rights framing of Islamic sexual repression that mistakes state repression for sexual repression. The warias' stories of leaving their villages, separating from their families, and fleeing to the city to find spaces to survive as waria may seem to strengthen a capitalistic, individual story that says freedom is found in individual agency outside the confines of family and religion. Puar may suggest that this discourse of free city, oppressive village makes me complicit in privileging and valorizing certain classes, ethnicities, linguistics, that have access and wealth to live an urban life, yet I would describe the metropolis as a heroic milieu not to inscribe the village as less than, but to describe the metropolis as a more layered space for complex assemblages. Puar avers the terms queer "assemblage" or "intersectionality" are more effective terms to use instead of a queer "identity" because the word assemblage or intersectionality highlight convergences and "deprivileges a binary opposition

${ }^{46}$ Ibid., 5

${ }^{47}$ Ibid.,13. 
between queer and not-queer subjects." ${ }^{\text {48 }}$ Identity presumes that components such as religion, gender, and race can be separated from a person, and that by naming these separate categories there is a stabilization across time that is actually fictive. Assemblage undermines a coherent identity.

Elliot warns that we need not reduce similarities to sameness or differences to "exceptional, the unrecognizable, or the unintelligible" in order to promote broad solidarity. ${ }^{49}$ If queer theory and transgender theory is seen as seeking to unsettle traditional categories of subject positions, and transsexual theory seeks to stabilize traditional categories of subject positions, then that speaks about our own illusions, our own operational subjunctive, our own pretending there is something called stability or instability, man or woman. It speaks to our own meaning making.

${ }^{48}$ Ibid., 205.

${ }^{49}$ Elliot, Debates in Transgender, Queer, and Feminist Theory, 153. 


\section{CHAPTER THREE: WARIA IDENTITY}

I am arguing that gender is conceptualized differently for the waria community than it is for a Western audience. In the West, gender identity is primarily based on biolgocial sex, i.e., the presence or absence of a penis. This mode of thinking entered Indonesia with the coming of Islam and was reinforced with Dutch colonization. But the waria do not privilege biological sex although this changes in ritual performance spaces such as during public prayers. The waria think of themselves as waria (gender identity) because of their expression and surprisingly, because of their sexual orientation. Because Dua, one of the original members of the pesnatren, wears make up, designs clothes and jewelry, wears a wig, she presents herself as feminine and this makes up a significant part of why she does not see herself as a man. But unlike the West that separates sexual orientation from gender identity, sexual attraction sutures a gender identity onto the waria.

I asked Dua, "How do you know you are a woman?" She responded, "Because I like straight boys, and my first experience was when I was 12 years old. I had a boyfriend that was in college. I would lock the doors of my bedroom and put on make-up and go out on a Saturday night." Dua references her sexual attraction to men immediately when distilling what woman-ness means to her. Not only does Dua conflate sexual desire with gender identity, she designates the object of her desire as "straight boys." This means Dua does not view herself as romantically desiring sameness which is what homosexuality is; she desires men that desire a different gender, be that women or waria.

The waria consider themselves heterosexual as do their clients and boyfriends. Dua tells me her ex-boyfriend was her ideal type, but "he asked me to stop consuming pork because it is forbidden (haram). I told him that having me was haram as well!" Dua labels her gender as female/waria and her and her boyfriend's sexuality as heterosexual, yet she points out that this heterosexuality can be evaluated as forbidden if biological sex is foregrounded vis-à-vis the three other components of gender: identity, expression, and attraction.

"Waria just want to be waria," says Merah who also considers herself heterosexual. "They do not want to be women, so they will have their penis and a sexual orientation towards men." 
Repeating the standard litany of questions I addressed to all my informants, I queried, "What makes someone a man or woman?" Merah responds, "A real man has a heterosexual orientation, is physically strong, and takes care of a woman; while a woman has female genitals, has a heterosexual orientation, can give birth, can take on house-wife duties, children, and serve her husband. Those are Indonesian perspectives of men and women." She lets me know that these categories I am inquiring about are not as important as the problems her community faces: access to education and freedom. "All people before God are the same and equal. The only difference is in our good deeds, morals, and piety."

\section{Identification Cards}

Indonesian Islam has been held, like Turkey, as a model of moderate Islamic belief and practice. In fact, this reputation, along with the Buddhist complex of Borobudur, was part of what piqued my interest in Java; however, when other Indonesians quietly asked me if I felt safe walking outside during the Presidential elections of 2014, I wondered how much integrity this moderate persona warranted. Kees van Dijk writes that orthodox Muslims sometimes call Indonesian Mulsims "Karta Tanda Penduduk" or "identity card" Muslims to reference a perfunctory religious status. ${ }^{1}$ But a stricter form of Islam has gained strength in Indonesia. The abangan or what Clifford Geertz referred to as a syncretistic form of Islam with Hindu, Buddhist, and animist influences has become less common, and some militant organizations such as the Front Pembela Islam (FPI), which translates as Front Defenders of Islam, who have a headquarters in the Yogyakarta, aim to create an Islamic state and not a secular one. The Majelis Ulama Indonesia (MUI), which translates as the Council of Indonesian Religious Scholars, issues fatwas that often reinforce increasingly conservative mores throughout the nation, thus supporting an Islamisization of the archipelago which would create one official religion. The Deputy Minister of Religion told me, "We are preparing a bill now on how to treat religions other than the six we recognize because our constitution allows anyone to adhere to any religion. But we have two laws that prevent this; a 1965 law on blasphemy and a demography-citizenship law relating to

\footnotetext{
${ }^{1}$ Kees van Dijk and Jajat Burhanuddin eds., Islam in Indonesia Contrasting Images and Interpretations (Amsterdam, Amsterdam University Press, 2013).
} 
identification cards. You must mention one of the recognized religions on your ID or you won't pass the religious education requirement and continue in school." He explained that if two parents don't have a religion typed on their card, the hospital will not issue a birth certificate showing the father's name, only the mother's name.

National identity cards not only single out a citizen's religion in Indonesia, they also single out gender. But unlike religion which can be nominally practiced, gender is thought of as a constant and fixed category. The historical record suggest that this fixity does not arise until after Indonesia's Hindu-Buddhist empire ended and Islam came to the archipelgago starting in the thirteenth century. And an even stronger gender binary of man and women did not arise until Dutch colonization occurred in the 1700 s. One of my informants, Dua, a waria that converted to Catholicism but now has a disdain for all religions, said she wanted a new identity card and went to her village to ask for one. She inquired, "Do I have to have a sex change operation to get a new ID?" The response from the local official was, "We already consider you a woman of this village, and if you are not comfortable with your given name, you can change it." Today Dua has an identification card that says she is a woman. This card also gives her the right to vote which many waria do not have because they would have to go back to their home villages dressed as men, face their family which many have run away from, and obtain family documents to present to the court.

It is worth noting that Dua first asked if she would need a medical procedure in order to legitimate her claim of woman-ness. The village official's response was that her legitimization came from the consensus of the community; "we already consider you a woman." This suggests that local conceptions can override national and global narratives of what constitutes womanness and man-ness. Most waria do not consider a sex change operation which implies removing the penis, and none of my informants had this done. Perak, the leader of the space where waria pray and study Arabic and Quran, told me she considered undergoing a sex change from a doctor she heard about in a major city on the other side of the island, but she decided against it. Both Dua and Perak have gone to college and have worked for non-governmental organizations 
that dealt with HIVIAIDS and have picked up Western discourse on gender and sexuality more than the majority of my informants who talked about body modification to look more feminine. Even with Thailand being relatively close to Indonesia, removing the phallus almost never done by the waria.

Dua identified as both female and waria meaning she clearly recognizes her male body as her biological sex, but also recognizes her waria/female gender identity. Dua tells me that although she thinks of herself as a woman, she is not completely comfortable with that. "I'm the only waria that the women in my village asked to join their tambourine musical group, but because I had to wear a hijab I didn't fee comfortable. I quite after three rehearsals." The fact that Sony did not want to don a headscarf that popularly indexes female Muslim piety relates to another element of gender I call gender expression. Gender expression is a major component of what makes up a gender identity and it involves actions, dress, demeanor, and mannerisms. This expression is gendered in Indonesia much like it is in the US, as either feminine or masculine. I met Dua in a rural café next to a rice field at night where young Indonesians go to play music and secretly drink alcohol. She showed up with a group of friends who I assumed to be all men, but she informed me they were are "priawans" or female-to-males.

The 1974 Indonesian Marriage law does not allow for waria or priawan to marry a person that has the same anatomy as them; moreover, couples of mixed religion are not allowed to have a legally recognized union and when one is single, the required identification card says "blum kabil" which translates as "not yet" married. Satu, an informant of mine who identifies as a gay Indonesian and is a professor and activist, tells me the grammar of Bahasa Indonesia boxes one in and "you have to be un-Indonesian to say "you are asking the wrong question." There is a concept called the Sapir-Whorf hypothesis that contends that language shapes cognitive abilities and how one views the world. Benjamin Whorf proposed the concept suggesting that linguistics might even determine thoughts, and this poses a theoretical dilemma for those academics that 
would like to see worldviews made commensurable. "I teach this in my social linguistics class because, although critiqued, it is an exercise in seeing the connection between language, thought, and culture." The Indonesian national identification card creates a discourse that assumes a heternormative life trajectory, and I wonder if this contributes to what Satu calls other Indonesians inability to imagine an alternative culture where same-sex relationships are just are legitimate as heterosexual ones.

Satu is also referring to a gender regime that was constructed in the New Order's ideology (1965-1998) with President Suharto attempting to control and homogenize the nation with goals of wanting to control the population and lower the birth rate to enhance the economy. Gender based on anatomy was part of that ideology. While kinship ties and marriage have historically been organized by adat or local custom, foreign religions and economic systems have mutated such structures. The New Order's 1974 Marriage Law and family planning program challenged the adat and Islam to regulate personal relations. Kathryn Robinson in her book Gender, Islam, and Democracy in Indonesia argues that the New Order suppressed "forms of identification outside the definitions provided by the state; a denial of the 'multi-layered citizenship' imagined by the nationalists in the motto 'Unity in Diversity."”3

\section{Waria History}

In anthropologist Tom Boellstorff's book A Coincidence of Desire, he theorizes about the connections Indonesians make on the local, national, and global levels. Academic disciplines have paid little attention to queer subjectivities in the archipelago, but there is growing US governmental concern around Indonesian linkages to global politics as evinced by the US Department of State's proclamation that Indonesian is now a critical language for US study to contribute to national security.

\footnotetext{
${ }^{2}$ Emily Ann Schultz, Dialogue at the Margins: Whorf, Bakhtin, and Linguistic Relativity (Madison, Wis: University of Wisconsin Press, 1990).

${ }^{3}$ Kathryn May Robinson, Gender, Islam, and Democracy in Indonesia (New York, NY: Routledge, 2009), 87.
} 
The waria live in a postcolonial nation, and they identity themselves as a national identity shared across the archipelago and not limited within certain ethnicities or professional ritual specialists such as the bissu (androgynous shamans) of South Salawasi. Boellstorff argues that the "waria are not a 'third gender' but rather a male femininity." He asserts this hypothesis based on his observation that two toilets were available at a waria lip-synching contest where one toilet was marked wanita, or women, while the other was label pria/waria, or men/transgender. ${ }^{4}$ Boellstorff also uses the English word "transvestite" to describe the waria saying this is the term that his informants used to describe themselves. ${ }^{5}$ This was not true for me. My research in Yogyakarta was outside Boellstorff's localities of study and may show a difference in regional uses of terms, perhaps due to the concentration of English speakers and university students in Yogyakarta or the type of nonprofit organizations connected to the waria. My informants consistently translated "waria" to "transgender" or "female" or both.

According to Boellstorff, the word "wadam" appeared in the 1960s as a nonderogatory term for what is now called the "waria." The "w" is explained as coming from wanita (women), and the "adam" as a referent to man. In the 1970s the periodical Temp suggested that the term waria came from the Arabic term "hawa" (Eve) and "adam" (Adam). Incorporating the name of the Islamic prophet Adam into the moniker for the male-to-female transgender community upset enough folks that the minister of religion, Alamsjah Ratoe Perwiranegara, coined the term "waria" to replace "wadam", "a decision apparently supported by President Suharto and made official when published in the newspaper Kompas on June 7, 1978."

Indonesia is known by Americans for its association with coffee (Java) and the tourism industry (Bali), yet Indonesia is the most populous Muslim-majority country in the world with few considering the implication of this. Few are also cognizant of Indonesia's history as producers of

\footnotetext{
${ }^{4}$ Boellstorff, A Coincidence of Desires, 82.

${ }^{5}$ Ibid., 223.

${ }^{6}$ Ibid., 224 Boellstorff quoting from Budiman, Amen Wadam: Pengertian dan Masalahynya. [Warias: Understanding Them and Their Problems]. Semarang: Tanjung Sari.
} 
nutmeg and cloves thus earning the moniker of the "spice islands." First colonized by the Portuguese and then the Dutch, this European colonization morphed into Asian colonization when Japan took over Indonesia at the beginning of Word War II. Indonesia declared independence in 1945, and Indonesia's first president was Sukarno who ruled from 1945 until 1967. Sukarno's reign was labeled the "Old Order" by Indonesia's second president, Suharto, who ruled from 1967 until 1998. Once Suharto resigned in 1998, a liberalization of the political, media, and religious landscape created an environment for both extremism and democracy.

In the early 1800 s, there began to be some references to male transvestites among certain trading ports linking them with commerce and not ritual. A Dutch dictionary maker in 1855 cited the word banci as an emic term referring to a male transvestite. ${ }^{7}$ In the 1937 book Island of Bali, which was republished in 1997, the author, Miguel Covarrubias, put Bali on the tourist map and referenced a population of transvestites. ${ }^{8}$ Boellstorff notes that the male-to-female Indonesian became newly marginalized starting in the 1950s with new strains of Islam. Suharto's New Order which began in 1967, and its accompanied violence, led to decreased public gatherings which pushed the warias out of the public square.

Boellstorff's position that the waria do not constitute a third gender is partially defined by how the waria reconcile their Islamic theology with their subjectivity. When asking what a waria's gender is, they will often reply: "waria." When asking if God created three genders, they will often reply God created them male with a female soul. This response contributes to Boellstorff's thesis that waria is a subtype of male gendering; however, I would argue that it is not helpful to collapse the waria into a type of male-ness, but to see them as a unique assemblage on multiple spectrums as our conceptual model presents.

Gender Completion

The youngest member of the pessantren is Empat, a young twenty-something originally from the island of Lombok. She tells me that "the waria were born as men, but have a women's

\footnotetext{
7 Ibid., 85.

${ }^{8}$ Ibid., 86.
} 
soul-like those who were born without arms or legs." I am a bit struck to hear Empat describe her subjectivity as a disability so I ask her to clarify. "It's not a physical disablility; it's one of the soul. Waria just were not born complete. We are imperfect because we were not born completely woman or man."

Physical or mental disability was an explanation some religious leaders, like Persik, had to explain certain waria. Persik, is a teacher at a pondok pesantren I can see from the porch of her house. She wrote a master's thesis on the topic of waria in 2003 , before there was a pesantren waria. She informs me about the two Islamic categories for alternative genders: khuntha (Arabic for intersex) and mukhannath (Arabic for transgender or effeminate). She says the exegesis of hadith from the ulama (scholars) distinguishes between mukhannah who impersonate women for fun, and the mukhannath who impersonate women because of an identity conflict. Although this real/fake model will have negative ramifications for drag queens and gay men, Persik accepts this religious logic. She tells me the waria are generally not homosexual, but some are, the ones who "go against nature and are sick." She says that Islam defines gender based on genitalia but "we cannot see the waria from this perspective. The religious leaders need to cooperate with other disciplines like medical, sociological, psychological perspectives before making laws and interpreting the teachings not textually, but contextually." Persik says interpretation (tafsir) of the Quran must consider place and time of the writing and the present. As she speaks, she jumps up and dashes behind her curtain door returning with a bottle of milk and an infant at her side. "Most people see him as an abnormal human," she quips letting the milk dribble down her baby's face as his large brown eyes struggle to focus on me. "This is Salak." Although he is almost two-years-old, I notice he is unable to sit up by himself. "He has down syndrome. The Quran says that some can be born abnormal. Physically he has two hands, two feet, but he has different chromosomes. I am a special parent because I have a special child, and this is a gift." I nod gazing at the limp body of her differently chromosomed child suckling, and remember Empat's description of the waria as a disability of the soul, although I did meet some religious leaders that saw the waria as having different chromosomes. 
Empat identifies as a waria, but points out that her boyfriend (who is married to a biological woman) considers her "a woman, and not waria, and that is the only thing I don't like about him." Empat is clear that although she wishes she was born a woman and even wishes that she could have a sex change operation, she in fact is not. Empat and Putih are the only two informants that stated they would have a sex reassignment surgery (sometimes called gender confirmation surgery) if they had the financial means to do so. Most waria have internalized an Islamic discourse that it is forbidden (haram) to permanently modify the body, so these two are outliers. "He wants me to have a vagina and breasts, and I do want to have the surgery, but I still want to be defined as waria." Empat admits that she desires to have breast implants, but when I ask her if she wants bottom surgery for herself or her boyfriend she says she is unsure. Empat explains that surgery will not really change that she was born with a man's body. A recurring concept from all my informants was that if a body is born into this world with a penis, then that body should be gendered as male upon death, even if it was gendered as female before death.

"If I have surgery, I could become a woman and change my sex on my ID card, and get married." It seems as if there is a contradiction as Empat talks about gender, but based on the previously discussed four elements that make up a waria gender identity, we can see a type of emic logic. Empat's biological sex at the moment is male because of the presence of phallus, testes, and $\mathrm{XY}$ chromosomes. Using our conceptual map, this is how Empat would plot her points.

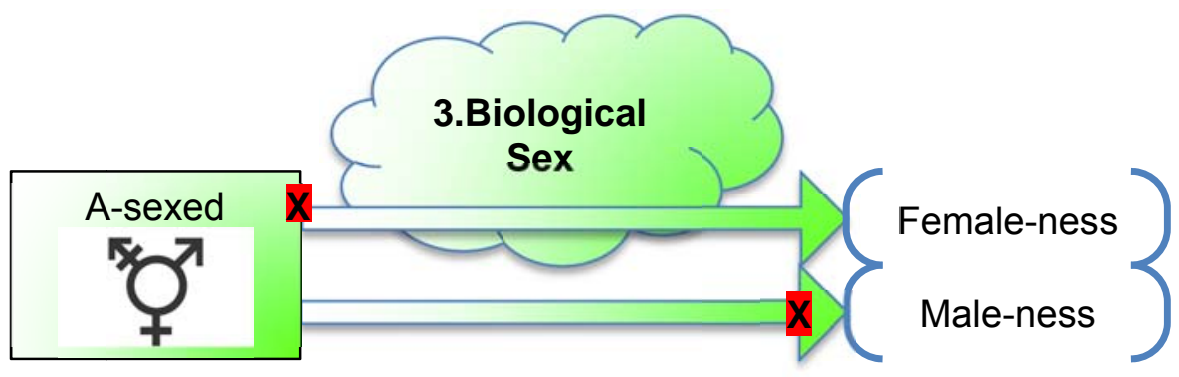

But even if surgery removes this phallus and medical procedures giving her "female attributes, I am still in a man's body." Empat's biological sex spectrums will have different plot points after surgery, but she sees her body as still male even after a vagina is contructed 
because she will not have the internal organs of a uterus, ovaries, and other female organs, but will retain male internal organs. This could be her biological sex spectrum post surgery.

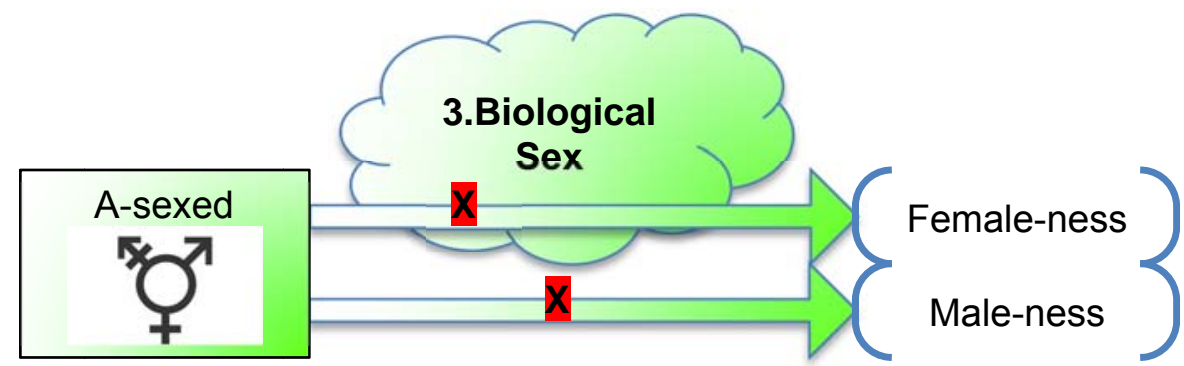

Empat sees herself as becoming "a woman through surgery" if she is allowed to change the status on her identification card thus allowing her to get married. This is a turn away from the West's individual notion of an isolated identity and privileges national belonging with legitimization coming from a nationally mandated form of identification and marriage license. Acceptance, recognition, and belonging exist in concentric circles in Indonesia with neighborhoods and villages forming local custom (adat) which can accept marriages that may not be legally recognized on a regional level. And regional marriages by island may not be recognized by national law because Indonesia has no provision for civil non-religious marriage.

\section{Waria Marriage}

Perak is the leader of the pesantren waria is a married women who defines her gender as both a "woman trapped in a man's body" and as a "waria or transgender who is between a man and woman." When I asked her to define what a "man" is, she responded, "a human being who has a penis and has sex with a woman." Perak's answer conflates biology and attraction and reveals a dual belonging in-between woman and man which can be plotted on the gender identity spectra like this:

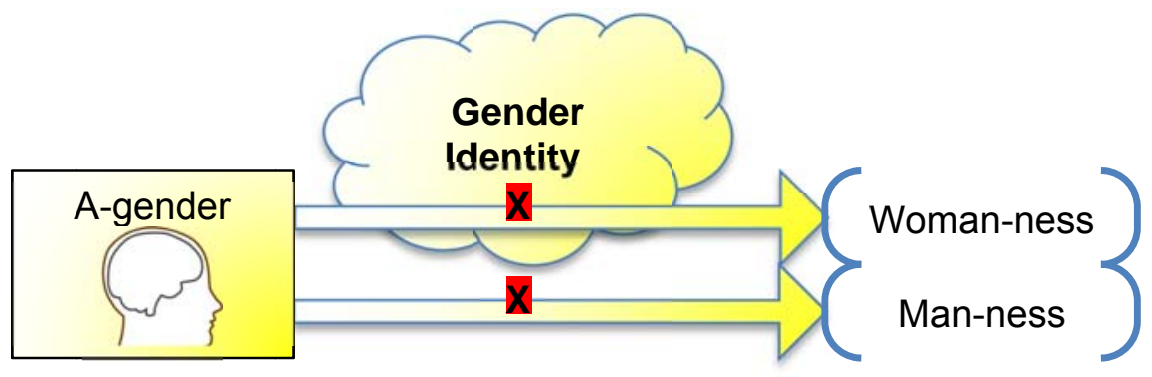


Perak continued, "my gender is sexual expression, not just the body's sex." This denotation highlights gender identity as an imbrication of biological anatomy, "the body's sex," and sexual desire. In the West we separate gender identity and sexual orientation as two related, but independent elements; for the waria, and Indonesia, they are also related but in a much closer way, like twin sisters instead of second cousins. The waria's sexual desire contributes to how they perceive gender identity.

This cultural logic explains how some waria could look at me perplexedly and say they don't understand how I could be a "real man" and want to be sexually intimate with other real men. If sexual orientation gives the waria a large part of their gender identity, it is strange to hear an American who claims his gender identity is not related to his sexual orientation. On the conceptual map, Perak's sexual orientation plot points look like this.

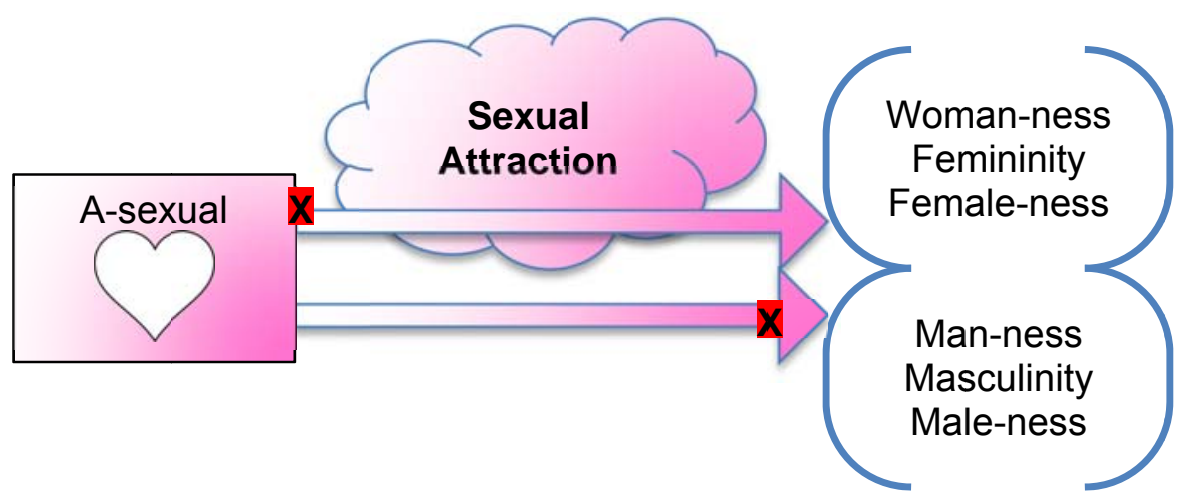

Perak explains, "A man is a person who has sex with a woman, but a man who has sex with a man, he is homosexual and not a real man." This overlap of gender as comprising sexual attraction and biological anatomy is made even clearer when I follow up with the question: Do you consider yourself a man or a woman? Perak asserts, "I am a waria; I am not gay, and I am not straight. I feel I am a woman, but physically I am a man." I directly framed my question to understand how Perak deals with gender dimorphism. I received a response that spoke to a binary sexual orientation, and three categories of gender identity: waria, man, and women. Perak exclaimed, "I wish I had been born a real man or real women although I receive this wholeheartedly—it is all God's gift. 
Perak married a man when she was 25 -years-old as his second wife, a practice that was discouraged even for heterosexual couples during the dictatorship of Suharto's New Order. With the dissolution of the New Order in 1998, polygamy has become a hot button issue for Islamists who want to assert a more conservative identity. She formally introduced her fiancé to her parents, and married him in 1987. Since only heterosexual marriage is recognized by governmental agencies, this was considered a "family marriage" and accepted by the community. After the marriage dissolved in 1995, she met her new husband in 1997. The second day I visited Perak she was making wedding preparations for her husband to marry a biological woman. She said that although he lives in the same house with her, they have become more like roommates and is happy to see him take a biological wife. Perak's inherited property houses herself, her daughter whom she adopted from her first marriage, her soon to be ex-husband and his new wife, and a few renters. The ex-husband is a taciturn man that was usually doing some metal work when I occasionally saw him near his workroom. I could not persuade him to be interviewed.

\section{Waria Family}

Kuning is Bu Perak's 22-year-old daughter. She was adopted at two months and Kuning has never known her biological mother, only her waria "mama." She realized at 6-years-old that her mother was different when she was bathing with Perak and saw male genitalia. "I wondered, why does mama have a penis and I don't?" Kuning feels grateful her mother cares for her. In fact she says that the love of waria is greater that the love of real woman. "Mama gives me the love of a mother and father because she is waria. If I come home late, she educates and disciplines me, as a mother she loves me more than she loves herself. She always protects me." Kuning is in close contact with her biological father and says she dropped out of high school to get married, although she has been divorced for a year now. She says she married young because she got pregnant and "disgraced the family's name." Although Kuning has an alternative family, this doesn't change the cultural proscriptions and proprietary behavior expected of family members, particularly around concepts of familial honor and shame. The baby stays with her ex-husband in a neighboring town. 
In a hushed tone, Kuning reveals that she used to be a lesbian but never told her mom because she thought she would be angry and upset. I'm a bit nonplussed by this remark since I would assume Perak would be the most accepting. Kuning can't seem to explain why she has this thought. "I was hurt by a man and became a lesbian, but thank God it did not last and I am normal again." I feel myself becoming both aggravated and fascinated that Kuning' language reveals that she thinks of herself as being reared in an abnormal environment.

Since motherhood is seen as an essential role for women in Indonesian society, I suspect Perak's status as mother contributes to how she experiences her gender identity. During one conversation, Perak told me that others feel comfortable as waria, but not confident. Perak said she feels both. Several informants defined a woman as being able to give birth, being nurturing, and runing a household with children; Perak is the only informant that comes closest to this ideological ideal.

\section{Nested Gender}

Putih is a case that points to how the four elements of gender in our model insect in a unique assemblages. Putih is a 50-year-old waria who has been coming to the ponpes for over two years. She moved from Medan, a city on the island of Sumatra, to Jogja to find the pesantren waria and kick her addiction to narcotics. In 2009, she saw a televised expose on the pesantren waria and felt a desire to incorporate religious teachings into her life. Putih relates to me how being waria is part of her destiny and fate. This is a common theme I hear which will be explored in chapter 5 . She thinks of herself as a woman,

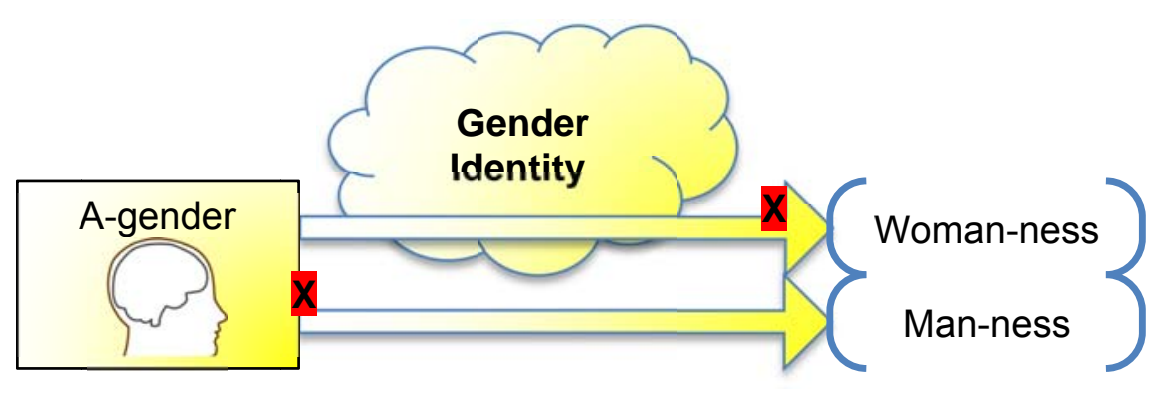


and when I ask her about her sexual orientation, she first tells me she dresses as a woman (gender expression) and that her desire is for men (sexual orientation).

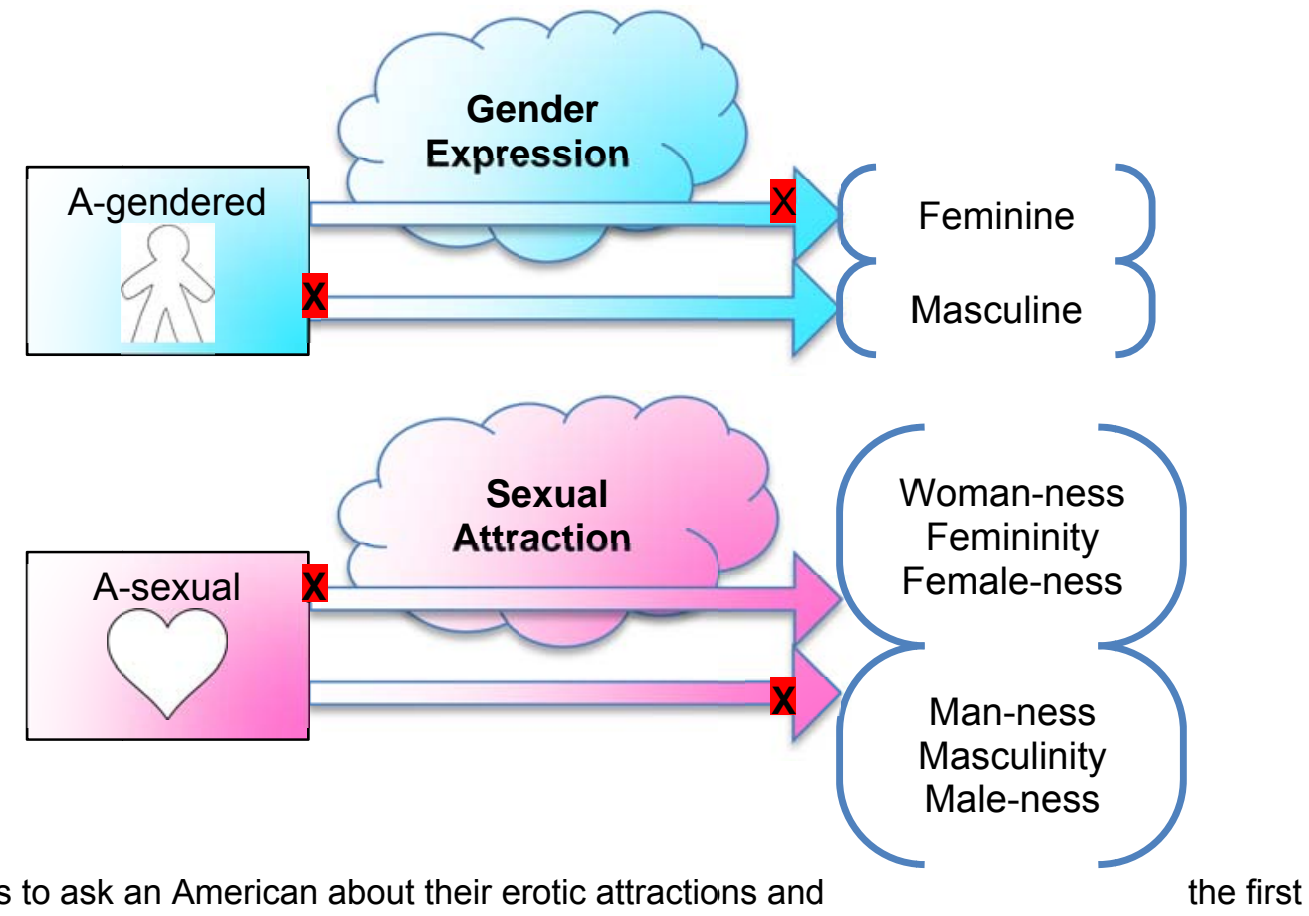

If I was to ask an American about their erotic attractions and

response was about clothes worn, I would find this puzzling, but in an Indonesian context, gender elements overlap in ways that are not typical to a Western audience. In this case, gendered dress shapes how Putih perceives her sexual desires. Putih stresses the heterogenous nature of the sexual relationship between her (a woman) and other men. I ask, "What is a man, and what is a woman?" "A woman is a person who gives birth and gets pregnant, whereas a man is a person who leads a family." Putih is defining gender identity through biological sex (organs that grow a fetus) and gender expression (leading a family), while tying sexual orientation to gender expression (feminine attire) and desire (for men). She later recounted the struggle of being both Muslim and waria because when she thinks religiously she is "half woman and half man."

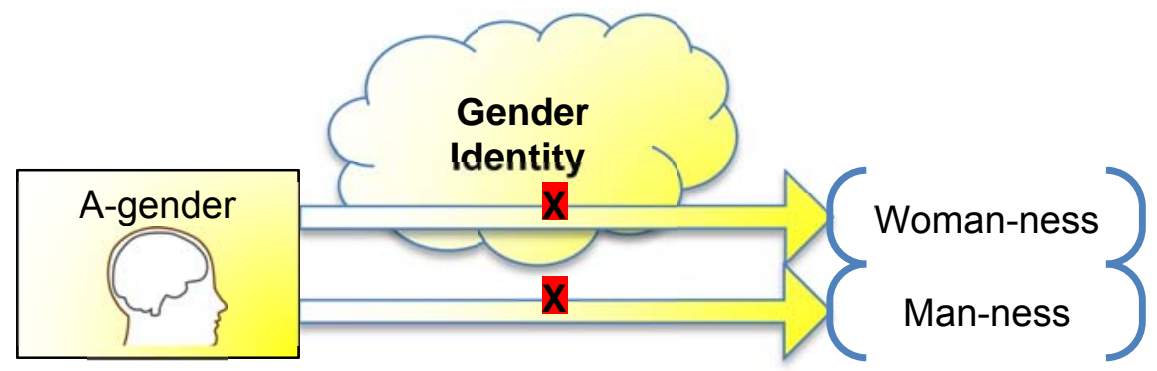


In other words, her gender identity on a male-female binary fluctuates depending on context although this does not change the larger constant of a waria identity. This fluidity speaks to the deeply contextual nature of how the waria perceive themselves depending on situation. Putih was the only interlocutor I had that concretely stated she would have full sex reassignment surgery that "not only removed my penis, but gave me breasts because I want to be a real women."

Merah, another informant, also brings out the imbrication and fluidity of gender elements that form a waria subjectivity. Like Perak, Merah is the only other waria I met that finished university. She says she knew she was waria by the age of 6 . It is clear that she is educated by the way she peppers her speech with Javanese, Indonesian, and English terms such as "heteronormative systems" and calling for scholars and scientists to more closely study gender and sexuality. Indonesia is the most trilingual country in the world with close to 18 percent of the population speaking Indonesian, Javanese, and English. Merah references a national scale when I press her to define the term waria. "We are an integral part of family, society, and our course the nation. There are many types of waria from Sabang to Merauke." The two localities she names span from the most northwest part of Indonesia to the easternmost city creating a sense of (imagined) national identity. "Waria is someone who declares themselves transgender by having characteristics of women, male genitals, and same-sex orientation." She identifies three elements that make up gender identity: gender expression, biological sex, and sexual orientation. This is another example of how sexual attraction plays a larger role in the waria's conception of gender than it does for most western audiences. Merah qualified waria's sexual desire as pining for sameness by calling her desire "same-sex orientation" as if the male genitalia she mentioned trumps the waria's other female characteristics (breasts, long hair) and feminine attributes (dresses, make-up). Putih articulated difference in terms of the waria's gender vis-à-vis men, and Merah iterates sameness when speaking about anatomy.

Oranye privileges "role," what I am naming gender expression as the determining factor in her gender identity. Oranye is a 47-year-old, Jogja-born waria who has been active in the pesantren since 2010. She describes her mother as a mosque-going citizen and her dad as 
kejawen, a term used to describe a mixture of Javenese traditional beliefs of animism with Sufism. "It means I had to find my own shape to religion when I was little," she tells me. It seems the same holds true for her gender identity. "I am not comfortable when they call me a woman or a man; I am comfortable calling myself waria. I have a woman inside me with a physical appearance of a man. I don't say I am half man or half woman because my role is predominantly female even with some masculinity."

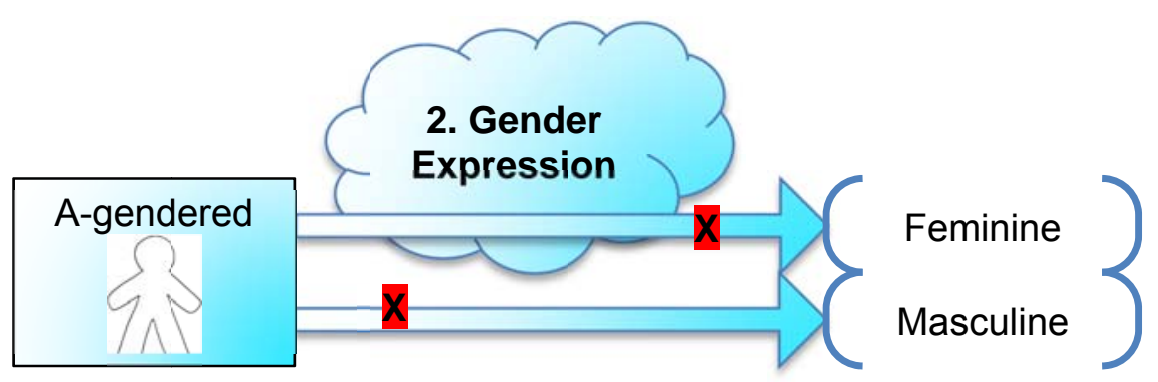

Oranye describes any sexual contact she has with men as heterosexual. My next informant, Hitam, privileges gender expression and sexual orientation to shape her gender identity.

The pondok pesantren waria came to Hitam, she did not come to the ponpes. She was renting a room, with her husband of five years, at Perak's house when the pesantren moved there in March 2014. Hitam is a 46-year-old waria who spends Monday through Friday making money shaking an instrument and soliciting pedestrians. She stands in front of storefronts and vendor carts singing until the (annoyed) owners hand over some rupiah. "I am a waria—woman, but man. I was destined to be a man, but I like to dress up like a woman, even biologically I feel I am a woman. I knew I was waria since 12 years of age when I was interested in men and comfortable dressing as a woman." Desire and dress are the linked themes that most strongly index a waria's gender identity. Most of my informants brought up sexual desire in regards to how it comprised their gender identity and expression, not sexual orientation. This is similar to what anthropologist Don Kulich notes about the travesti community in Brazil who "invert the roles of male and female through their practices of grafting female attributes onto a male physiognomy." ${ }^{\prime 9}$ And like the travesti community, being waria or taking a feminine role is bounded by an erotic interest in other

\footnotetext{
${ }^{9}$ Don Kulick, Travesti: Sex, Gender, and Culture among Brazilian Transgendered Prostitutes (Chicago: University of Chicago Press, 1998a), 9.
} 
men in a way that combines gender and sexual orientation as one conceptual category. Both the travesti's of Brazil and the waria of Yogyakarta see sexual desire as significantly creating gender. Men are men because they desire women. Women and waria are just that because they desire men. Although Kulich argues the travesti's gender is established by what takes place between the sheets, the waria are more complex because of the history of Hindu-Buddhist dynasties throughout the archipelago along with the slow spread of Islam over the archipelago over last 900 years. The Javanese and Hindu-Buddhist discourses around gender formation allowed for gender ambiguity in the way an individual comported with gender roles and sexual conduct. The waria establish their identity not only through internal attraction to men as they point out when I ask them to define waria-ness, but also by their gender expression, and partially because of Dutch colonial and Islamic influences, by their anatomy.

Hitam is the only waria, other than Perak, that lives at the pesantren. She has a boyfriend and they share the same 16 by 10 room rented from Perak. Hitam refers to him as her husband and when I ask her if he would consider himself "straight or gay?" She tells me "he is 100 percent man." My question about sexual orientation is answered with a statement about gender identity revealing the close connection sexual orientation has to gender identity. Sexual orientation in the sense that one's internal disposition makes for a public identity is generally thought of as a Western conception. The fact that a lesbian, gay, or bisexual public identity in Western Europe and the US has morphed into various social movements and identity politics loads my words with a set of assumptions that I do not mean to impose on the waria. I am using a Western model to break up elements of gender in an attempt to understand how Indonesian individuals and communities conceptualize and construct gender.

Gay is thought of as an identity in the West based on a sexual orientation or an attraction to someone of the same gender, and this identity makes claims on public space such as legal marriage recognition, adoption, military enrollment, economic spousal benefits, medical access and decision making for oneself and one's spouse. This conceptualization of gay identity is generally not found in Indonesia since sexual attraction to and/or sexual conduct with someone of 
the same gender does not traditionally make claims on public space with a discourse of human rights. Relationships—sexual, familial, platonic-have different functions in different cultures, and the West's fixation on only one partner of a particular gender that fulfills all sexual needs is a modern discourse and way of thinking. In Indonesia, polygamy is not illegal (although not encouraged), but the conception of how sexuality is lived out in a Muslim context is different than the West. Tom Boellstorff italicizes the word "gay" when he indicates that ideas and behaviors around same-sex contact is specific to geographical area. Furthermore, Jasbir Puar argues that all identities are made up of elements that are specific to class, ethnicity, sexuality, and place. I am arguing that because the waria mark themselves with make-up, female attire, silicone, and other feminine accouterments, they are making a claim on public space that is not similar to an Indonesian gay or lesbian subject position. The waria's visibility, which has increased over the last 30 years due to the media landscape and more waria dressing as women in daylight, has a closer relationship to the rhetoric of Western LGBT visibility and rights even though the waria have their own discourse of their gender subjectivity.

In Hitam's case, she confronts my conception of "straight or gay" by calling out her husband's gender identity, not sexual orientation: "he is a 100 percent man." She continues, "His family thinks of me as a woman and we visit them during Idul Fitri." She further affirms her gender identity in relation to her husband indicating the performativity of gender to borrow Juditih Butler's concept. Butler sees humans as iterating a scripted role that every culture presents, yet in each articulation, one can slightly modify the performance thus creating something new. These articulations of gender roles are always in relation to a cultural framework and individual actors, thus the words we speak and the actions we take are texts read by an audience and have meaning. For Hitam, her husband's man-ness and her families perception (especially in relation to a religious holiday) gives Hitam meaning, in fact, it gives Hitam her gender. She indirectly includes herself and husband in a heteronormative regime through her interpretation of gender identity because she sees herself as woman and her husband as man. 
Through my conversations with Hitam she would call herself a woman, waria, transgender, and "woman, but man." When I ask Hitam how she knows her gender is waria she answers, "since I was 12 years-old I was interested in men. I feel comfortable dressing up like a woman." Hitam explains her gender identity by referencing first her attractions to men, and then her feminine behavior of wearing clothing for women. Desire and dress, or what l'm calling sexual orientation and gender expression overlap in a way that grounds Hitam's conception of what waria means.

\section{Complicating Gender}

Coklat, in her early fifties, knows she is unique because as strong as her female identity is, "physically I am a man, but in my heart and mind I am a woman", she does not like to wear makeup, the litmus test of wariahood. “I felt like I was a woman, but I didn't look feminine. I didn't like to wear women's uniforms and I also don't like makeup. I would only wear lipstick to attract my customers. All of my behaviors are like a woman's: speaking and acting." In an interesting way, Coklat's suspension of feminine expression in attire is similar to the pesantren members suspension of feminine expression in a ritualized context, only Coklat's is in the secular sphere and not religious.

She has never worn women's clothing and only wore makeup as a visible hook to draw an income through sex work, even describing herself as a "tomboy." I wondered if it could be possible that Coklat actually thought of herself as a man who found it easier to fit into the known cultural category of waria to legitimize her attraction to men. I asked her about what it means to be gay. "Gay men are physically men, behave like men, and are interested in men, but I am different. I am physically a man, but have a women's heart, so it is normal that I like men. Generally, waria dress up-like women, but I dress up like a man." Here, Coklat ties a gay sexual orientation to gender expression and erotic desire by saying gay men act like men and sexually desire the same. Her next sentence describes her gender identity but locates it in the heart "so it is normal" for her to like men. The rhetoric here, whether conscious or unconscious, places her gender identity as a woman in the symbol for what represents pathos and desire: the heart. She 
situates herself in what is "normal" sexual desire because of this emotionally placed gender identity of woman-ness, thus Coklat links gender identity with sexual orientation mimicking the gender and sexual binary in currency throughout Indonesia that normalcy is heterosexual desire. I am inquiring into Coklat's conceptualization of gender, not to impose etic categories of "gay" and "man" as found in America upon her, but to further unpack how assemblages of social, religious, cultural, educational, and political influences shape and are shaped by subject positions. When I ask about the historical role of waria on the island, she offers "waria is more easily accepted than being lesbian, gay or bisexual because for so many years there have been waria here." In chapter 6 I will explore the historical roots of the male-to-female subject position.

Hijau does not question Coklat's waria-ness even though Coklat does not dress as a woman. Hijau is in her early thirties and sporadically attends the pesantren. She tells me she knew she was waria in first grade although she did not dress as a woman until she was in her mid-twenties. She says she is an architect even though she only completed high school. "I stopped being an architect because I had to dress up as a man and I was not comfortable at all. I had money, but money doesn't guarantee happiness." As Hijau got older she confirmed she was waria because she "fell in love with a man instead of a woman." When I inquire into her gender status she responds by describing her sexual orientation, that is, her falling in love with a man. Emotional and sexual attachment to men is a necessary variable in the making of the waria subject position. Additionally, being born with a penis, whether it is still intact or not, is another constant. The last constant is one's internal sense of identity: female or waria. What is in flux is how and when masculinity and femininity is performed through action, dress, demeanor, and social interactions based on perceived gender norms. Hijau says, "waria have male genitalia, but dress up like women, and consider themselves as women. I am a woman." Hijau sets the criteria for wariahood based on biological anatomy, feminine gendered dress, and how one considers themselves; a criteria that Coklat does not meet. Coklat's biological status (male), self-identified gender identity (waria), and sexual attraction to men is enough to establish her credentials as a waria even though gender expression through clothes (along with sexual desire for men) is what 
usually grounds waria-ness. Coklat is an outlier in the sense that she complicates what elements create a waria gender identity.

Hijau: In my village they discriminate; I was born a man.

David: Would you say you were born waria?

Hijau: I was born with male genitalia.

David: How would you define what a man is?

Hijau: Men love women. They are stronger, arrogant, and gentlemen.

David: And women?

Hijau: And women tend to guide people, are more beautiful, and more gentle.

David: Do you consider yourself a woman or a third gender?

Hijau: I consider myself a woman and I love men.

David: What is your sexual orientation?

Hijau: I am not gay; I am a waria.

In this conversation, I speak about gender with a Western assumption of innateness. The waria speak of destiny, but not innateness in the sense that an identity is present from birth. When I ask for a denotation of "man," the first response indexes love, "men love women," which implies sexual desire. Hijau follows this definition with perceived masculine characteristics, "stronger, arrogant," that make for a man's gender identity. She also references sexual desire when she calls herself a women. This supports my argument that sexual orientation grounds a waria/female identity.

When I press for a label to define Hijau's sexual attraction, she responds with what she is not, "not gay," and then affirms what to an outsider seems like a gender identity (waria), but in emic terms, waria affirms an identity and an attraction. I did not meet any waria who sexually desire women (although Dua told me she does know some). There is no mention of biological anatomy when Hijau defines the category of man because it is assumed that all the physiological phenomena of testosterone, $\mathrm{XY}$ chromosomes, testes, penis, deeper voice, more hair, wider shoulders, thinner hips, larger muscles, and in Hijau's case arrogance is incorporated into the evaluation of man-ness. She did evaluate herself as being born a man, but the minute she was asked to describe what a man is outside of her own birth, her immediate response is "men love woman," that is, a man is a being that desires sexually, romantically, emotionally, physically, spiritually another being that is different: a woman. Conversely, when describing her womanness, she links it to her sexual desiring of men. She concludes, "I am destined to be this way. The 
sacrifice of becoming a waria is so hard-it is against our family, friends, society-the acceptance process takes a long time."

To simultaneously hold a sense of being man and woman, same and different, opposite and aligned is to inhabit the world of the waria. Delapan is from West Sumatra and is one of the younger participants in the ponpes, being in her mid-thirties and a member for 3 years. She is the treasurer of a nonprofit that advocates for LGBT rights. When I ask her what it means to be waria she links her gender identity to gender expression and sexual orientation: "Being waria is expressing our femininity inside us and our interest in the opposite sex, despite the fact that we're actually the same sex. We identify men as our opposite, and we feel we are women interested in men." Delapan reveals a paradox in thinking; she says she is both the opposite and the same sex as men. Before living in the waria world, Delapan felt "like I was living in the wrong zone which did not belong to me and made me unable to enjoy my life." Delapan had one year left of university when she dropped out "because the academic atmosphere could not accept my new identity."

Delapan is the only interlocutor who brings up the idea that she could have been considered "gay" when she was younger. Delapan works for an NGO that advocates for LGBT rights. Her environment surrounds her with more gay men and woman than transgender people, so she is as at ease discussing this topic. Our conversation is taking place inside her office building. "I felt I was waria when I was younger because I was fascinated with men. Being in love with men may categorize me as gay. I did not announce myself as waria at the time; I just knew I had a dominant sexual orientation to men and no sexual feeling toward women." Delapan's discourse echoes the common pattern of the waria's attraction to men who display masculinity, and this sexual orientation provides the basis for a waria subjectivity. The waria emphasize the inner dimension of sexual orientation—feelings of attraction—and secondarily the sexual behavior that can accompany such feelings. One notch down on the hierarchy of elements that ground a waria subject position is feminine expression by way of dress, demeanor, walk, speech, and role such as cooking. 


\section{Gender Expression}

Biru explains to me that gender is based on "physical appearance and the way people walk." She is explicitly foregrounding gender expression here, and I assume biological anatomy is part of her definition of "physical appearance." She goes on, "So waria are both man and woman." I usually sit outside the prayer room/living room on the veranda when the waria are performing prayers (salat). It is not uncommon to see a waria complete their supplications and immediately jump into a conversation about a handsome fellow or a fashionable piece of clothing. The waria may pray as men, but their gender identity actually does not change. The waria's gender expression temporarily registers as masculine indexed by their wearing of a sarong and hat (peci). Although gender expression is crucial to an Indonesian understanding of what creates gender, a temporary masculine gender expression in a religious context does not change the other two strongest elements that make up gender: internal identity and sexual attraction. The waria can complete their ritual obligations before God with deep piety, and seconds later strut a catwalk as if they received a trophy for most beautiful waria. At times, and to their great entertainment, I would muster the fiercest RuPaul impersonation I could and swish out a catwalk with them. An intern student from Jakarta, who had been visiting the ponpes daily for two months, exclaimed, "David! Your walk is more ladylike than the waria!" I'm sure this feminine comportment only furthered their bewilderment about my own gender identity.

Identity Building

Satu is the most prominent LGBT activist in Indonesia which is why he received death threats while working on the fourth National Gay and Lesbian Congress which was cancelled in 1999. ${ }^{10}$ He founded the NGO Asia Pacific Coalition on Male Sexual Health, and in 2000, he left his tenured position at Surabaya University to join the socialist People's Émigré Party since academic bylaws didn't allow him to be a civil servant and party member simultaneously. At 60years-old, he says his outspokenness comes from his mixed heritage of Chinese and Indonesian descent (called Peranakan), Dutch values, and his New York based university education. Satu

${ }^{10}$ Tom Boellstorff, "The Emergence of Political Homophobia in Indonesia: Masculinity and National Belonging," Ethnos 69, no. 4, (2004), 468. 
says that all organizations, including his own, have to register with the Ministry of Law and Human Rights. "There can be no words like 'gay', 'waria', 'sexuality', even 'gender' in our title or description of our mission. This isn't even a rule, just someone's squeamishness who works at the Ministry." Becoming increasingly animated, he says he is tired of the assimilationist attitude he finds among the LGBT community. He says his colleagues "can't even imagine a different world, or if they can, they say that is for the West." Satu wants to see gender and sexual minorities build a stronger identity that can oppose the dominant culture of what he sees as assimilation.

Nanas is another activist who is manadated to build up the LGBT community. He is the executive director of the oldest non-governmental organization in Indonesia created in 1957: the Indonesian Family Planning Association also known as PKBI. ${ }^{11}$ He holds a master's degree from the same Indonesian program I enrolled in, Cross-Cultural and Religious Studies, and aligns himself with Nahdlatul Ulama (NU). He says PKBI started working with the waria in 1987 primarily because of the AIDS scare. For 20 years PKBI dealt with the physical health of the waria community until they realized they were contributing to the waria's marginalization. "We realized we were stigmatizing the waria indirectly with our HIV-AIDS prevention by saying you are risky; you are the epicenter of HIV; you are unhealthy." The group changed from a behavior modification model to a community organization model. "We decided that the community was not only about their body, but also about their identity: gender and sexual." He said meetings were created where, in addition to immediate physical health needs being addressed, PKBI started asking the waria long-term questions about sustainability such as, "What is your vision of your future?"

Nanas says he was on the ground floor when he and Lima, the first leader of the pesantren waria, were brainstorming about creating a religious space for waria as part of PKBl's community organizing. He says he and some waria got the permission from a kyai (religious leader) named Hamroli Hamron, who named the pesantren Al-Fatah (The Opening), and five

\footnotetext{
${ }^{11}$ Firman Lubis and Anke Niehof, Two is Enough: Family Planning in Indonesia Under the New Order 1968-1998 (Leiden: KITLV Press, 2003), 247.
} 
other local kyai gave their blessing to the newly created ponpes. Kyai Hamroli (now deceased) stepped down as head of the ponpes several years back when a scandal broke out in the community. Apparently, he gave a statement to reporters that he was changing the waria back to men and this prompted Lima and Nanas to visit the kyai's home, a highly unusual (considered immodest) move, to find out why he did this. According to Nanas, the the kyai explained that his remark was based on a misunderstanding: one of the volunteers in the ponpes lied and told Hamroli that Lima requested to be buried upon death as a man when in fact Lima requested to be buried as a waria. Nobody seemed to remember the year or month this took place, and my archival search in Jogja's local newspaper office did not turn up any results. Nanas and the waria community approached religious leaders to legitimize their enterprise much like PKBI approached the two major Islamic organizations, NU and Muhammadiya, at the beginning of the New Order in 1967 to amass support for their population planning programs around contraception. ${ }^{12}$ Piety always has a political dimension.

Nanas tells me that teachers in Java confuse intersex individuals (khuntha) with transgender individuals (mukhannath) and there are two types of mukhannath from an Islamic perspective. Real mukhannath are born transgender and this comes from God, while fake mukhannath act like women as an affectation. He says a fake mukhannath entered the Prophet's wife's room and this is the type of mukhannath that the Prophet rebuked in a hadith. When speaking about the waria in English, Nanas uses the gender neutral pronouns "ze" and "hir" displaying an awareness of gender inclusive language that usually comes with an activist orientation. When I ask Nanas how Islam defines what is a man and what is a women, his answer is biologically based, but more nuanced. "Commonly, Islamic teachings are based on the presence of a penis or vagina, but what about khuntha? So it depends on where the urine comes from; if it comes from the penis then he is a man." Nanas is referring to a medical condition called hypospadias where the urethra does not extend to the end of the penis which complicates the Islamic definition of gender. "Our challenge now is to go deeper and reinterpret the verses.

12 Ibid., 258. 
Gender is like treble and bass in stereo. I am heterosexual, but sometimes I gender myself as a little bit female, maybe 43 percent because gender is my choice. Gender is a verb and fluid so I can be more feminine if I am facilitating a discussion."

I am struck my Nanas's metaphor. In stereophonic sound there is more than one speaker transmitting sound waves, so there are different places in space where the sound is emerging. One channel of sound is comprised of both higher tones on the treble clef and lower tones on the bass clef that coalesce into an ensemble of vibrations emitted though multiple audio channels. The effect is an illusion of a unified audible field. Nanas's reference to two different frequencies, "treble and bass," is similar to the double spectrum on our conceptual map. Degrees of womanness and man-ness can be held in the Indonesian mind where in the West, only one spectrum is commonly used creating an either/or mentality instead of an and/with mentality. Perhaps mindset comes out of the Kinsey rating scale published in 1948 that placed men on a 1 through 6 single spectrum with 1 being completely heterosexual and 6 being homosexual.

Nanas is quick to qualify his comments. "I say that gender is fluid, is an action, but that can have a negative potential because one can say we can then train the waria in male mannerisms. If I claim myself as transgender because gender is fluid, then I can deny that the waria have an identity struggle and this is a negative too." Nanas is pointing out the shadow side of constructionist and essentialist identity politics. But this doesn't leave him impotent, Nanas deploys what Gayatri Spivak termed "strategic essentialisms"13 to tactically take action depending on context. For instance, Nanas tells his staff to speak about the waria as being transgender from cradle to grave when face to face with the FPI, but within the safety of the ponpes, it is fine to speak about gender being fluid. Nanas is describing what is known as rhetorical context, that is, persuasively communicating a purposeful message to a targeted audience within a specific situation. From my fieldwork, I found the waria take an essentialist approach to gender identity and a constructionist approach to gender expression, that is, they have the thought they are destined to be women or waria, and feel most comfortable behaving in masculine and/or feminine

${ }^{13}$ Bauman, Religion and Ecology, 212. 
ways depending on where they are situated.With Nanas's open stance toward modernity and Islamic jurisprudence, I wonder where he finds the most resistance from his co-religionists.

"There is a hierarchy. It is easiest to defend abortions, second is transgender, then gay, and last is sex-work."

Like Nanas's treble and bass metaphor, I find the multiple spectrum conceptual map useful for the same reason anthropologist Don Kulich, who spent a year with Brazlian travestis, does not like the conept of "thirdness" when it comes to gender. He writes, "There is a real danger that theories of third gender in fact radically naturalizes and reinforces traditional understandings of sexual dimorphism, by suggesting that individuals who do not fit the malefemale binary fall outside it and transcend it, rather than disturb it, blur it, or reconfigure it." ${ }^{14}$ In other words, the concept of thirdness is akin to otherness and does not confront the assumptions of the male/female gender binary. The waria do not so much fall outside the binary as reconfigure and complicate the binary, sometimes by reproducing it by imitating female characteristics, and sometimes resisting it by how they pray or modify their body, a topic we turn to next.

\footnotetext{
${ }^{14}$ Don Kulick, Travesti: Sex, Gender, and Culture among Brazilian Transgendered Prostitutes (Chicago: University of Chicago Press, 1998b), 230.
} 


\section{CHAPTER FOUR: WARIA BIOCAPITAL}

The waria struggle to make a livelihood and use cosmetics, body modifications, dress, beauty, and their bodies to increase their income earning capacities. At the pesatren waria, with students, journalists, and researchers visiting, the waria use their story and voice to make extra money by sharing their experiences with those interested. The waria work in what is known as the informal sector, outside the taxation of regulated business. Most of my informants engage in sex work and the income they gain is what I am calling biocapital.

When my plane landed in Jogja and I walked toward the airport entrance, the first image I saw was a cardboard cutout of a waria called Raminten. Frocked Raminten was propped up enticing new arrivals to frequent her epinomous restaurant known throughout town (for the gay wait staff). I quickly learned that Raminten, with her handful of restaurants and large souvenir store, is the economic exception to the harsh reality most waria face. Most waria, having run away from school and family as teenagers, rely on physical attractiveness to make a living. White skin is one marker of attractiveness. I had to dutifully search to find regular soap that did not have some bleaching agent in it while in Jogja. The waria also go to wizards to obtain "beauty needles" or "open their auras" to attract more clients which will in turn bring wealth.

Beauty is power to the waria. The concept of power is taken up by Foucault and Butler in a way that questions how models of knowing and truth come into being. Butler writes that the relationship "between intelligibility and the human is an urgent one; it carries a certain theoretical urgency, precisely at those points where the human is encountered at the limits of intelligibility itself." ${ }^{\prime 1}$ This bespeaks of the human need to be understood which is a form of recognition. Butler believes that a recognition of a coherent gender is necessary to be recognized as human, and that an unrecognizability of gender is on par to not recognizing one's personhood. The waria want their beauty to be read as feminine if not fully woman.

Defining gender is not a clear-cut process. Dr. Milton Diamond, an endocrinologist, suggests the presence of a $\mathrm{Y}$ chromosome is grounds for gendering a body as male. Bulter

1 Judith Butler, Undoing Gender (New York ; London: Routledge, 2004), 142. 
points out, in Undoing Gender, that some doctors see the full phallus as the criterion for raising a child as a boy. ${ }^{2}$ Since surgery can lead to mutilations, scars, and lack of sexual function all in an attempt to look "normal," would it seem "incommensurable" to let someone who is intersex alone? Is the rush to surgery really about fixing a body or about making a decipherable human? The country of Malta in March 2015 became the first country to outlaw medical professionals from performing unnecessary surgery on intersex infants. I did not meet any waria that disclosed they were born with ambiguous genitalia, but since many have modified their bodies, we can view them with mixed anatomical attributes since many waria have breasts. This hybridity challenges our notions of coherence and normativity; this mixing threatens the gender dimorphism that seems to be the underlying assumption of what makes one fully human.

The gender binary of male and female is just one model to map the human on. My aim is not to argue the merits of a social construction nor genetic determinism of gender, but I hope to better understand the discourse the waria use to make their lives legible. There is an apparatus of knowledge being applied to the waria community by virtue of living in a Muslim-majority state. I assert this Islamic grid of knowledge shapes how the waria perceive themselves. There is a plurality of gazes specifically upon the pesantren waria, and audiences as well as regimes of knowledge influence how a subject presents and performs. My informants described themselves in a language and a culture that existed before they did, so they were born into a linguistic social system with ideas of what is normal and real versus what is not normal or inauthentic. The waria I spoke with all realized at some point how they did not fit the norm, the norm of what constitutes masculinity.

In Foucault's three-volumes, History of Sexuality, he examines the history of sexuality, not sex; that is, he looks at government's relation to sex vis-à-vis the body as an erotic zone. Foucault's work focuses on networks of power and knowledge that organize societies. Sexual identity, according to Foucault, has a history and has a discourse that creates types of subjectivity. The "truth" of a subject is shaped by the social discourses that surround sexual

\footnotetext{
${ }^{2}$ lbid., 64.
} 
practices, body types, desires, and identities. Although sex is a bodily function, the way we understand that function changes through time and across cultures. ${ }^{3}$

In a Foucaultian model, sex is a physical act that often leads to reproduction which links individuals to a kinship pattern that can involve a transfer or wealth. On the other hand, sexuality is a psychological act where desire and discourse mingle with institutions that impose propriety. If sex orbits around the physical body, then sexuality orbits around the physical and social body. Although the same (sexual) body parts may enact the same activities, those activities are given different meanings depending on the context. For the waria (like all of us), sex is not just about procreation or pleasure, but it is a form of knowledge that informs what we do and do not desire, what we do and do not despise, how we think of ourselves as autonomous or dependent, powerful or enervated. With a nod to Foucault's scientia sexualis, I counter that the waria community engages in a supervivere sexualis, or a survival sexuality since their sex and sexuality is commercialized to exist day to day.

The evaluative categories that came out of the medicalization of sex, like "homosexual" are not so new since same-sex desire and gender/sexual minorities were a reality during the Prophet's time. The waria, or a type of archipelagic gender/sexual minority, have a history as evinced in the Centhini Story, a compilation of $17^{\text {th }}$ century tales, and like Foucault, I am not only interested in their erotic desires and bodily practices, but in their meaning-making processes and discourses about what sex and gender are and how that changes based on place and context. The waria make sexuality visible and Indonesia is dealing with sexuality more overtly as the AntiDomestic Violence Law passed in 2004 makes clear since it criminalized martial rape. ${ }^{4}$ Sexuality has also become more of a public issue with a 2008 law outlawing pornography. Homosexuality is legal in Indonesia except for the autonomous region of Aceh that enforces sharia law. Religious

\footnotetext{
${ }^{3}$ Geoff Danaher, Tony Schirato and Jen Webb, Understanding Foucault (London; Thousand Oaks, Calif: Sage Publications, 2000).

${ }^{4}$ Linda Rae Bennett and Sharyn Graham editor Davies, Sex and Sexualities in Contemporary Indonesia: Sexual Politics, Health, Diversity, and Representations (Milton Park, Abingdon, Oxon: Routledge, 2015), 6.
} 
conservatives see the waria as homosexuals because they are male-bodied, and this is reinforced by a heteronormative state whose ideal family is defined by the nuclear family. At times, the state even requires marriage certificates in order to share a hotel room between. ${ }^{5}$

Although all my informants tell me they wish they had the option to perform work outside of prostitution, they feel forced into sex work in order to survive. The waria say employers will not hire them because they transgress gender norms. At the same time, some informants talk about the benefits of sex work: autonomy, higher than average pay, and even sexual pleasure. My informants moved to the city to not only earn an income but to escape from what Sharyn Davies called "kinships of shame" ${ }^{\prime 6}$ since embarrassment in not only brought upon oneself for engaging in sinful activities, but upon one's entire family as some on my interviewees expressed. This kinship of shame is part of the reason that a visible gay identity is not widespread throughout Indonesia. The waria may be shamed, but if they develop a cordial relationship with their community, they can be accepted like a women, and if they are in a relationship, that union may be seen as heterogendered. Such social networks that shape and surveil sexuality can be called "village biopower" since they regulate subjects into compliance with social norms. This village biopower was parlayed into state biopower through the 1974 Marriage Law that legislated heterosexual marriage if both parties share a common religion.

Emas was one of the regular attendees that came to the pesantren every week and spoke to me how she employs here body to make a living. We became fast friends despite our language barrier and she was one of the few waria that I felt comfortable enough visiting inside her home to ask any question I had on my mind. Emas lives in a two-room home with a bathroom and kitchen adjacent to the house. Jennifer Lopez and Britney Spear posters wallpaper the background as we chat in her living room. She tells me she gets $\$ 5$ to $\$ 10$ from her usual university-age clients for ten to fifteen minutes of oral sex. Although she would like the opportunity

\footnotetext{
${ }^{5}$ Ibid.,12.

${ }^{6}$ Ibid., 35.

${ }^{7}$ Ibid., 47.
} 
to leave sex work, in typical Javanese style, she synthesizes optimism and practicality saying, "If I don't enjoy my job, I will not succeed." Emas, like all my interlocutors, identify their sexual prostitution as sinful, but more importantly, identify their need to survive. I know how seriously Emas takes both sin and survival because right before heading out the door in full "drag" to clock in, she prays for forgiveness (for the $\sin$ ) and wealth (to survive). Emas repeats what others have said: employers will not hire waria because of how they look. "Our space is limited," she tells me.

There are officially 35 members of the pesantren waria, but usually I observed 5 to 10 members that regularly attended. "I study gender in the Quran; that's why we organized the pesantren. God never said, 'Oh, woman people or man people, rich or poor people, God said, Oh, my people, do as much good in your life so that your life will be good later."' It is telling that Emas described gender and economic status when speaking about God's inclusivity, the two most salient themes that reoccurred throughout all my conversations.

Highlighting economic status and gender, Emas commented, "I don't want to be a transsexual, and if I had the money, I would use it to start a business." Although the waria do not use money to become "transsexual," they do employ their capital to modify their body in other ways: namely with silicone and hormone pills. When Emas was 29 years-old, she did what was popular throughout the 80 s and $90 \mathrm{~s}$, have a friend inject silicone into her face "to look more beautiful-have longer noses like Europeans." Emas wanted to have a longer chin, so that is where she did her silicone injection while also swallowing hormone pills for two years to develop breasts.

The waria want to be recognized as feminine and go to great lengths and expense to buy make-up and clothing to appear as such. Several of my interlocutors did have other jobs, but decided that if the cost of employment was the depression that came from dressing and acting as a man every day, then that price was out of their range. Emas explains, "I used to work in an institution, at a property office, but they mocked me. They wanted me to be strong while my soul is the soul of a woman." 
Perak sees herself as one of having the strongest woman's soul because "she celebrates her waria-ness before Allah," meaning she prays as a women unlike the other pesantren members. I found Perak on Facebook before I arrived knowing she was the gatekeeper to the waria pesantren community. With her very limited English, I arranged to meet at her house to discuss my project. Watermelon in hand as a peace offering, Perak and I sat on her couch and discussed me entering her world for a summer. She was clear about the requirements, make a $\$ 10$ payment to the pesantren, and make a payment to each member formally interviewed, and be a supportive presence. At that moment, I did not fully realize how much the waria had learned to commercialize their bodies including their stories, sex, voice, and time.

\section{Victim of Silicone}

One informant, Eva, described Perak as a "victim of silicone" as Perak walked by us. Perak seems to agree because when a television crew came to gather footage, I suggested to Perak that she change her drab brown hijab to her scarlet one because the color would look better or television, and to jettison the reading glasses she normally never wears. She said she wears the glasses to minimize her nose. Perak's nose is the largest and most disproportionate I have seen from silicone work. Kuning, her daughter, comments, "Most Javanese people have flat-noses and they want to have pointy noses like European people. Mama has too much silicone in her face." Perak has confessed that she sees herself as ugly despite her attention to appearance.

Putih used silicone on her face and chin in the $90 \mathrm{~s}$, and had plastic surgery on her nose. "We want to look modern and glamorous. We want to be like fair-skinned foreigners (bule) because the women are beautiful. We obsess over foreigners. Indonesian models have ordinary faces, but foreigners are beautiful." Putih is one of the few waria whose countenance does not conspicuously betray the pumping of industrial silicone since her facial features do not look distorted. And Merah also does not look distorted because she never used silicone. She went on a personal campaign warning her trans friends of Surabaya city about the psychological and medical danger of injecting silicone. She says that after the waria realize that their facial 
modifications are unsightly, some waria perform surgery on themselves by trying to take the silicone out since doctors refuse to participate if the procedure was originally done without medical approval. Biru, Perak's best waria friend, admits she too injected too much silicone and instead of making her beautiful, it has done the opposite. Biru had a friend in Jakarta perform an operation on her face where excess silicone was removed. She shows me the scar running along the side of her face. "If I went to a doctor, that would cost a lot of money, but a friend can do it at home even though I know many have died because the silicone enters the blood vessels." Hitam says too much silicone can be fatal since the polymer compound is injected into warias' breasts and can spread to the heart. Sometimes beauty is a matter of life or death.

\section{Trapped Opportunities}

Oranye conducts her ritual prayers wearing the traditional male garb of the sarong and cap (peci) although she appreciates when she sees other waria wear the female mukena body covering. She never uses the trope of being tapped in the wrong body, but she does use this language to refer to the occupations of the waria community. "Most of my friends are trapped in the world of sex workers." She tells me about the problem of HIV in the community and how she has not participated in sex work since 2005 , but later in the day she confesses she sometimes finds clients over the Internet where she can negotiate a higher price than she would bring in on the street. Since Oranye is employed by an LGBT non-profit called People Like Us, a shoot-off NGO organized by Indonesian Planned Parenthood (PKBI), she tells me she can be better rested since she is not up all night turning johns.

She says waria are "obsessed with being attractive and more beautiful" which leads to more silicone injections. Oranye received an injection once on her cheeks and nose; she also took hormone pills to develop breasts. I tell her that I perceive women as usually having smaller features, noses and chins, so why use silicone if it enlarges and not diminishes? "Our cheeks are more appealing enlarged. When we apply makeup it can be seen more easily." The waria do not apply makeup in a campy, overdone style. They are not drag queens, yet to a Western sensibility, 
and a younger Indonesian one, the facial silicone injections quickly leave the realm of aesthetically pleasing.

In the mid 2000s, Hitam had silicone injected into her breasts when she was in her midthirties, and says if she had enough money she wants "to be a perfect woman by having genital surgery." I have to take what Hitam says with a grain of salt because she often fabricates stories, but even if this is not totally true, it is telling that she equates perfect gender with the removal of her phallus. She says it takes multiple injections to get results, so she had four done at a cost of $\$ 100$ per injection. Hitam also speaks about Eurocentric ideas of beauty by saying the waria "want to be like European people who have pointy noses and nice cheeks. If the waria are old and their skin is wrinkled, they want to be injected so they look young and not wrinkled." She refers to her face as God's gift to her and she does not want to modify it, "but because God didn't create me as a woman, I will make by breasts bigger by myself." Hitam is exercising her autonomy in declaring she has the power to modify what God has given her. She is simultaneously resisting her assigned gender identity at birth (male) and reinforcing a gender binary prevalent in Java (woman) by creating breasts. Although Hitam uses the trope of destiny to describe why she is waria, she is not fatalistic in her outlook because she fuses kismet and kinesthetics; she accepts her life and exercises her freedom by turning to another potent source: Javanese wizards (dukun).

\section{Wizards}

Indigenous religion in Java made use of wizards known as dukun in Indonesian. Citizen from all classes, islands, and religious flavors frequent dukuns although they can have just as ambivalent a reputation as waria since they are trading in powers that can either be from God or from Satan. Clifford Geertz in his book The Religion of Java writes about the different types of dukun: midwives, masseurs, circumcisors, harvest specialists, and diviners. ${ }^{8}$ The waria frequent what is known as dukun susuk who are men (none of my informants said they ever sought a woman or waria) that insert metal needles under the skin. These men are thought to partially

${ }^{8}$ Clifford Geertz, The Religion of Java (Glencoe, III: Free Press, 1960), 86. 
inherit their spiritual power and acquire their power through study or ascetic disciplines such as fasting, meditation, and chanting Quranic passages. I was told by the waria that I could not find a dukun to interview since it was Ramadan and such magical practices are laid aside during the holy month.

Dukuns are sought after to increase the warias' biocapital which practically means the waria want silver or gold needles to be placed in their faces to enhance their beauty and attract clients that will become regular high-paying customers. Hitam used a dukun to compel her boyfriend who ran away with her motorbike to return with the bike and his love for her. After seeing Hitam distraught for about three weeks from imbibing alcolhol and cutting herself with a razor blade, she became much chipper when her boyfriend suddenly moved back into her room. "See, the dukun worked," she expressed to me with a smile on her face. Putih also says dukuns work. She visited a wizard to gain more clients when she was in Thailand. She would hold a small statue to her forehead before starting work and she swears it did generate more income. She had an agreement that she would take care of the statue for 5 years and not perform her Islamic ablutions (wudhu) before praying. She referred to it as black power and this is what is commonly sought after so waria can attract more customers during their sex work.

Biru, who is Roman Catholic, expressed that she visited a wizard once when she was young even though "it was against God." She described this wizard as using prayer and not magic to accomplish feats. She asked the dukun for susuk, the charmed needles made of various metals that are inserted under the skin. She says the waria go to increase their attractiveness which in turn can increase their wealth if they find clients with deep pockets. The susuk, which may have precious jewels attached to them, can also keep them safe. "Celebrities wear them too, but if you eat forbidden food, it can disappear," Biru tells me. Food that has been prayed over, she explains, will cause the needles to vanish, and it is important to remove the charms before death because such accoutrements hinder the dying process.

Hijau thinks 30 to 40 percent of waria go to wizards, but says that one cannot truly believe in God and believe in the power of the wizard. She said her brother died of typhoid, so her 
family called a dukun to find out why he contracted the ailment, and they found out a family member supernaturally caused the sickness because they were jealous of his business. "But I don't believe this. I believe in God only and maybe it was my brother's fate."

When I asked Dr. Pir, a Religious Minister located in Jakarta, about these magical practices, he quoted a hadith of the Prophet: "If you go to a dukun, your prayers will not be accepted by God for 40 days." Then added, "but many people go of course, especially for the election." Also referencing magic and politics, Satu, Java's most well-known LGBT activist whispered while glancing around the room to see who was is in earshot, "Suharto's wife apparently had beauty needles, and the current Prabjo Presidential campaigns, as much as it is supposed to be an Islamist campaign, had two female dukuns in the veil!" Satu seems genuinely shocked that a the pious symbol of a Muslim, the veil, would be appropriated by someone that practiced forbidden rituals. He continues, "And the explanation for the win of President Jokowi is that he got the supernatural revelation." Laughing, he remarks, "Nobody bothers to ask if it is from Allah."

Many Javanese believe that mystical power can be suddenly bestowed on those who will hold (governmental) power. Satu relates this mystical thinking to the tale of King Pangeeran Puger who ingested semen, a symbol of power. In Javanese tradition, if one is to rule the temporal realm, it is necessary to have power over the supernatural realm as well, and the Javanese kings were seen as the link between the visible and the invisible. Richard Parry, writing about an $18^{\text {th }}$ century Javenese King, chronicles "Pangeran Puger acquired it [divine light and legitimacy] from his dead brother, Amangkurat II . . . the dead king's manhood stood erect and on top of it was a glittering shine, only the size of a grain of pepper ... Pangeran Puger quickly sipped up the light ... . it was Allah's will that Pangeran Puger should succeed to the throne."9 The

\footnotetext{
${ }^{9}$ Richard Lloyd Parry, In the Time of Madness: Indonesia on the Edge of Chaos (New York: Grove Press, 2006), 102.
} 
concept of power and kingship still holds sway in the Javanese imaginare, though the personnel may come and go. ${ }^{10}$

When I asked Hitam if dukuns were sought out to cure health problems such as AIDS, she said she had never heard of someone doing this. "In this community, once a month, a doctor comes to the ponpes and checks on us or we go to the health clinic every three months to do a blood check to see if we suffer from HIV. Medical students who come to visit suggest we use condoms when we have sex. I worry about HIV so I only have sex with my partner and not anally, just between the legs." Belimbing, a religious leader and informant, sees the waria as the cause of the spread of HIV in Yogyakarta. He has a perspective that draws into focus the shadow side of "born this way" arguments for gender. If being transgender is not a choice, then it is a biological error or psychological disorder that must be fixed. "To become waria is not a choice," he allows, "but it is a mental disorder maybe caused by socializing with girl friends." Belimbing sees this disorder as causing a social problem. "Waria can't be accepted as workers at companies because they will bring a bad image and decrease profits. If they work for the government, they will distract others' concentration, so they work in beauty salons or as prostitutes which is why they spread disease."

Although the pesantren waria has not made any overt political moves, it may, like the Islamic Revival's women's mosque movement in Egypt, have political consequences since its presence creates a discourse which always relates to power. The waria do not strongly participate in the electoral process, make claims on the state, or use the court system to herald their rights, but their pious organization may have effects in the social field that gains respect and thus more political clout in the context of Yogyakarta. The analytical labor of this thesis is to explore how the waria and their pesantren unsettle assumptions while not striving to be a political force.

\footnotetext{
${ }^{10}$ Soemarsaid Moertono, "State and Statecraft in Old Java; a Study of the Later Mataram Period, 16th to 19th Century" Modern Indonesia Project, Southeast Asia Program, Dept. of Asian Studies, Cornell University, 1968), 68.
} 
Islamic tradition assumes that women are the objects of sexual desire and men the desiring subjects. Mahmoud writes it is "noteworthy that Islam, unlike a number of other orthodox religious traditions (for example, strands of Buddhism, Hinduism, and Christianity), does not place a high premium on the practice of sexual abstinence and regards the pursuit of sexual pleasure (within the bonds of a marital relationship) a necessary virtue both for women and men." ${ }^{11}$ For the pesantren participants, the Quran is not a source of authority mediated only by lettered scholars, but a text that gains meaning by being applied to their quotidian life, including their sexual lives. My waria informants undergo a dual training: religious and feminine. The body is a site for cultivation of womanliness and piousness which are both paths to more power."

\section{Public Secret}

Ungu is always color coordinated. Today she is wearing a lavender top trimmed with a floral design and a bow on one side. She carries a faux, magenta Luis Vuitton purse over her shoulder commenting how she found it for 50 thousand rupiah or 5 American dollars. Her leggings are a deep bluish-violet that match her flip-flops. I stare at her perfectly applied plum lipstick and lilac lacquered eyelids as she tells me her birth sign of cancer matches the color purple. Since she brought up astrology, I jump into what I usually leave for later: dukun and magic. "It's a public secret," she tells me. "The majority of waria who work as prostitutes go to the magician to keep their customers, but Mbak Hitam is going to the magician to forget her partnershe has a broken heart." Since I conduct most of my interviews at the pesantren I get to see Perak and Hitam about four days a week. I learn that Hitam's husband left her and stole her motorbike. I see Hitam sitting inside her room sullen and despondent; she has acquired some homebrewed alcohol to assuage the pain.

Ungu continues, "The magicians are Muslim on their identity cards only—they don't practice the teachings or pray. My grandfather was a magician. This is not allowed for Muslims, but if we have a problem we go. It is our culture. It is an alternative way to solve problems, like a sick person going to the hospital to get medication, only the doctor can not cure him, so he

\footnotetext{
${ }^{11}$ Saba Mahmood, Politics of Piety: The Islamic Revival and the Feminist Subject (Princeton, N.J: Princeton University Press, 2005), 110.
} 
decides to find an alternative solution—a magician. That way, they can find direct results rather than praying." In Islam, if someone believes in powers other than God, such as in traditional weapons, then this is called musrik.

David: Do you believe in the magician's power?

Ungu: Often times the supernatural really works. I see the difference between those prostitutes who use the magicians' powers to attract more customers and those who do not ask for help.

David: What is your gender?

Ungu: I cannot say I am 100 percent male or 100 percent female. My appearance is like a woman's, but that is superficial. The important thing is for me to be closer to God. I don't question my gender. People call me Mother $(\mathrm{Bu})$ or Father (Pak) - it does not matter. If I don't wear makeup and dress up, then I am a man, but if I do, then I am a woman.

Ungu, still in her early fifties, is articulate and composed. She began a program in infrastructure engineering in university but never finished. She says she behaves as "half man and half woman" with her family whom she lives with. "Some people call me sister (mbak) or brother (mas) and I know they want to respect me and my family." It is not a surprise that Ungu connects womanness with dress. She has wrapped a muted lavender scarf around her wig and face to stand in for a hijab. Since she is a makeup stylist and wedding organizer, she tailors how conservative her clothes are to match her customers' sensibilities. She has never heard of a waria having a sex reassignment surgery and thanks God she has never used silicone because she knows how dangerous it can be. Ungu thinks the waria have many talents, but religion can block them from being successful. "I have been a freelance makeup artist for 12 years, but artists are supposed to be women because in Islam men are not allowed to touch a woman unless she is his wife. The Christian teachings do not have this rule or say you need to wear special clothes to pray."

Many waria have died from HIV and I ask Ungu if this is the result of sex-work. "I do not think so, it is the waria who are not prostitutes who get HIV." Seeing my surprised facial expression, Ungu explicates, "The waria who are makeup artists or work in a beauty salon and who are not prostitutes - they use male prostitutes and they are the ones infected with HIV." It did not occur to me that the waria would pay for sex, when their own bodies are so often a tool for economic security. 
Dukuns are frequencted by all clases, ethnicities, and religious members across the archipelago. Clifford Geertz made the differentiation between the abangan (literally translating as the red ones) and the santri (students) in describing Islam in Java. The abangan can be thought of as eclectic with practices that layer indigenous animism, Hinduism, and Sufism. Munim A Sirry describes the santri as those students who attended a traditional Muslim boarding school (pesantren) and are either traditionalist or modernist/reformers. ${ }^{12}$ The santri can be considered orthodox in the sense that they strive to perform the five daily prayers, abstain from food and drink during Ramadan, and travel to Mecca, and follow the Quran's command to give to charity. The santri rely on the kyai (religious teacher), and the kyai rely on Nahdlatul Ulama (literally Awakening of Scholars), headquarted in Java, which is the most popular social organization that has over 40 million members, but both abangan and santri are known to visit dukuns.

Some modernists seek a direct interpretation of the Quran outside of the kyai, and renounce all dukun practices. The social organization Muhammadiyah, which has more than 20 million members is the largest organization that holds such a belief. Modernists can be liberal with views that support equality for religious minorities such as Christians or they can be conservative wanting women to cover their heads with a hijab (headscarf), although this does not always index a conservative viewpoint. Interestingly, the most conservative Indonesian Muslims are modernist and not traditionalists. The divide in Indonesian society is not between Mulsims and non-Mulsims, but between "non-Mulsim, abangan Muslim, traditionalist, and liberal modernist Muslims on one side and conservative modernist Muslims on the other."13

"Islamist" is a term that connotes the fusion of religious and political ideologies that have been present in Indonesia since before independence. The role Islam would take in the newly formed nation-state was divisive since some wanted sharia to be incorporated and others did not. A day after independence was declared in August 1945, fearing that non-Muslim parts of the

\footnotetext{
${ }^{12}$ Ibrahim M. Abu-Rabi, The Blackwell Companion to Contemporary Islamic Thought (Malden, MA: Blackwell Pub., 2006), 467.

${ }^{13}$ Ibid., 468.
} 
archipelago would secede, leaders dropped a clause in the national charter that would require the President to be Muslim and the judicial system to be based on sharia; instead. The country was allowed to adhere to Pancasila, a Sanskrit word, meaning the five principles that would lay the foundation for Indonesian democracy: belief in God, civility, unity, democracy, and justice.

The term "santrinization" was coined by anthropologist Robert Hemer to describe a process where compulsive first and secondary education transformed abangan children into santri children. ${ }^{14}$ Educational institutions that introduced liberal ideas from within a traditionalist framework shaped generations of Indonesian Muslims. State Islamic schools called State Institute for Islamic Studies were set up to train teachers to teach religion in high school; however, they became domains of secular thought with western educated professors that taught tolerance for diversity, and as Munim Sirry puts it, "NU ulama are today among the most effective delegitimizers of the idea of an Islamic state.."15The NU network is the most sympathetic to dukun pratices.

\section{Divine Unemployment}

Coklat is in her early fifties and recently began attending the ponpes. She loves to read and graduated from high school. She struggles to find English words throughout the interview proud she has taught herself English skills. She is the only waria I spoke with that brought up the penning of the Yogyakarta Principles, a 2006 document massaged by a group of human rights experts in Jogja that describes how international law secures sexual and gender minority rights. She says she rarely attended mosque because she felt uncomfortable about her appearance.

Coklat was never interested in visiting wizards to gain beauty or inject silicone to attract more customers. "My weapon to attract people in the street is the way I speak-gently and slowly." It is true that Coklat has a light and airy demeanor that would be evaluated as effeminate

\footnotetext{
${ }^{14}$ Robert W. Hefner, "Islamizing Java? Religion and Politics in Rural East Java," The Journal of Asian Studies: Review of Eastern and Southern Asia and the Adjacent Pacific Islands the Journal of Asian Studies 46, no. 3 (1987), 533.

${ }^{15}$ Ibrihim Abu-Rabi, The Blackwell Companion to Contemporary Islamic Thought (Malen, MA: Blackwell Pub., 2006), 477.
} 
in the West, and although she says she never dons women's attire, she is wearing an androgynous silk scarf around her neck and has a unisex bob haircut. She also has sunken in eyes and I know from other members that Coklat is infected with HIV. About half of the waria sexworker community has contracted HIV, and although the ponpes turns into a clinic every three months with medical personnel coming to conduct free testing and counseling, it is still a taboo subject. When I bring up the prevalence of the disease in the community, she dismisses it saying "it is a problem for all people; a baby could get HIV from its mother, it's not a special problem here." A bit later in our conversation when I ask about her motivation for joining the ponpes she remarks, "I like to gather with my friends, and I am getting older and I need more support when I die."

Coklat asks a sibling in Jakarta for a monthly remittance of money so she can live and take care of her elderly mother. She tells me she used to work as a receptionist and in marketing at a hand-dyeing (batik) printing company on the island of Bali, but that was in the 80 s when she had a husband of 8 years. "I consider myself a high-level person because I worked in a hotel and could speak with people from all over the world. I would be so ashamed if I had to work as a street performer." But she says the shame comes from not being able to carry a tune. She reminisces about how she and her husband used to live with her mother and it was acceptable because Coklat was considered a woman. "But the problem was when I worked in the street, my mother would be bullied by my society and my father did not like it. My neighbors would gossip about my mother." In the end, Coklat and her husband separated so he could marry a biological women.

Coklat believes that God allowed a hate crime to be executed on her as a divine signal to change her behavior when she was in her early forties. "I was walking in the park around midnight as usual looking for customers. Some drunk guys approached me speaking very tenderly. I told them my friends would come in an hour and they suddenly punched my head and started hitting me. I tried to escape but I could not. I didn't have any enemies, so I was confused why they would do that. I was hospitalized for two weeks. I realized this was God's sign that I had 
to stop working in the streets." Coklat separates her identity and her behavior within her theological beliefs. "Being waria is not a sin although a lot of imams say it is; I am comfortable with my condition, but I don't want to work in the street anymore. I don't want that to happen to me again."

\section{Street Artists}

Sebelas is a new member of the pesantren and a new resident of Jogja since she had been living in Jakarta for the last 25 years. She spends six days a week, starting at 9 AM, singing Javanese along several busy thoroughfares in her new city. She makes between 20 thousand to 40 thousand rupiah for seven hours of work which is equivalent to about $\$ 2$ to $\$ 4$. She plays an instrument called an icik-icik, which is like a tambourine, but made out of small pieces of wood and Coke bottle seals. She says she enjoys the freedom she has as a street busker since she is

not being bound to one workspace. Sebelas went to school up until $5^{\text {th }}$ grade and says she knew she was waria by $2^{\text {nd }}$ grade, although until this day she does not dress like a woman when she visits her home "to protect my family's feelings and avoid gossip from my community and neighbords." Sebelas's motivation for joining the ponpes revolves around acceptance. "I wanted to join this pesantren in order to be admitted into society. If people ask me, I can say I have religion." Like all my informants, they dismiss those who call them sinful because "only God knows what is sin and can judge. It's important that I pray and get closer to him."

Tujuh lives with a group of waria that are all street performers like Sebelas; however, Tujuh is a different kind of artist. She came to Jogja because of the many universities the city offers and indeed Yogyakarta is known as a students' city with its low cost of living and concentration of institutes of higher learning. Although Tujuh cannot afford to attend a university, she thought she could learn from her friends that are matriculated. She says her family had money until her father's business collapsed during the 1998 Asian financial crisis. "To make money, I made crafts like kites and fake guns out of bamboo and sold them to my friends. There were several stupid students from rich families at my school, so I did their homework assignments for a lot of money. I needed the money for transportation costs from and to school since my home 
was far." She wants to see her transgender community economically independent and plans to purchase a building where waria can build small businesses, like running a café. ViaVia, a local restaurant owned by two European lesbians, gave Tujuh a loan to start her own t-shirt business. Tujuh sells her designs in ViaVia's giftshop, but she also volunteers at a hospital. "My father gave me a message before he died, 'You are born with nothing; if you want to help others you don't need to wait to have something.' Most people wait to have enough money and power, but I have my body, brain, and heart." She is clearly inspired by her father's words, not so much his religion. But as irreverent as Tujuh is, she knows what boundaries can and cannot be crossed. She never dresses like a woman in her small Muslim village to keep her family from having problems: indirect gossip and direct insults.

Tujuh doesn't easily succumb to cultural norms, even when the FPI places feces in plastic bags and throws it at her and her friends. She becomes upset thinking about her friend who was murdered a couple years ago. "My fried died while prostituting and the police still can't find her murderer because nobody cares about transgender problems. I tried to get help but was instructed to wait because I do not have money to process the case. The murderer took my friend's motorbike and jewelry. Her body was full of punctures. The NGOs for LGBT should be concerned about this, but they only work if they get funds for HIV testing." Tujuh has an entrepreneurial spirit and sees economic justice as the most efficient route to waria selfdeterminiation.

Strands of Islam may be under-nourishing the waria's spirituality, but more importantly, the waria would like to find ways to nourish their body and simply put food on the table. Satu says, "There was a national waria meeting in 2009 that agreed the Ministry of Labor should have an affirmative action plan requiring all institutions to hire a certain number of waria even if it is one or two. I'm not including the armed forces or police yet, but certainly civil service." Satu says his culture needs to look back to its old Javanese values of acceptance. "We need anti-bullying curriculum and teacher training as Thailand has now." He says the middle-class in Indonesia has become more intolerant and he finds poorer neighborhoods refreshing because they are more 
accepting. "They don't have anything to lose. They would say, 'Oh, my son turned out waria, at least he brings in money; at least he has got a salon." Acceptance is tied to practical usefulness in this value system that Satu is depicting. This concept is part of a broader Asian mindset that scholars have identified in Thailand and the Philippines that links family belongingness with degrees of responsibility that can bring the family status or material goods. In fact, the male-tofemale subject in Thailand, called kathoeys, is sought after by retail businesses because of their charisma. ${ }^{16}$ Satu continues, "If we compare Thailand and Indonesia, kathoeys are more visible than waria and they have been able to work in travel agencies and banks." I am told it is a Javanese quality to laugh in the face of hardship and the waria make the best of what life hands them. As Satu puts it, "If they're lucky, they will find a man that loves them, or at least pays them."

\section{Project Effect}

I wonder why so few waria have made the ponpes central to their life when it is a space for them to continually create and gain a sense of legitimization. Nanas, the Executive Director of Planned Parenthood tells me it is because of "the project effect." He describes how many educational forums were set up for the waria when PKBI was focused solely on HIV prevention. He said that participants would receive some money for every meeting they attended. "This made them dependent and see all projects as a way to make money. This was true even when the pesantren was at the original founder's, Bu Limaa's, house." He knows there are only a handful of waria that are devout in their attendance and Islamic practice. "It was Lima's personal charisma that made the pondok pesantren seem big to the public, but internally the waria accused her of taking big money from researchers and reporters." Nanas says the pondok pesantren's creation is primarily a political technique to give the waria a way into a religious conversation more than the pesantren as part of an Indonesian educational system.

Kuning says she is proud that her house has become a pesantren. "The atmosphere here is more fun and lively." She distinguishes between the waria that are proper and those that are

\footnotetext{
${ }^{16}$ Kang D.B., "Kathoey 'in Trend': Emergent Genderscapes, National Anxieties and the ReSignification of Male-Bodied Effeminacy in Thailand," Asian Studies Review 36, no. 4 (2012), 475-494.
} 
not. She uses her mother and Hitam, to draw the contrast. "Mama is motherly and Mbak (sister) Hitam likes to touch men." Hitam can be assertively flirtatious which intimidates most people. "Mama only touches men who are her customers when she works at night where Mbak Hitam touches all the guys she meets." Perak tells others she works in the silver business and does not disclose that she is taking customers in at night. Merah quit her teaching job to become a street performer and sex worker so she could wear women's clothing and not men's. She is not ashamed because "before God's eyes, all are equal; that is the core of the teachings of Islam. What distinguishes people before God is their good deeds; it is guaranteed in the Quran." I suspect Perak has a similar philosophy, but since she is the public face of the pesantren it makes since that she does not talk about her income producing activities.

Nangka, an employee of PKBI, brings up an issue I am reluctant to broach because I'm afraid my outsider's gaze may be contributing to an objectifying of the waria. "The ponpes is touching for me because God does not belong only to the heterosexual person. The pesantren waria humanizes and gives them a spiritual space, but there are so many photographers that come and they take pictures so closely." From the quiet university student to a major television crew from Jakarta, it was rare that some type of media outlet was not present at the ponpes. "I wonder if they are trying to say we are weird or if they have come to bond with us in this identity struggle. I mean, they [waria] are praying and it is a religious performance for them [media]." Although Perak is tired of answering the same questions, I get the sense that the waria like the attention and the remuneration. "Money is the problem; sometimes they do that for money and we have lost the essential meaning of a spiritual space."

Both Nangka and Nanas are surprised to hear that the waria request money from every reporter and researcher that talk to them. Apparently, Perak and PKBI agreed that money would not be charged for interviews except for a $\$ 10$ donation to be made to the ponpes. Visitors are supposed to send a copy of their work to the ponpes so the waria community can build a library. If a researcher spends more than a few weeks at the ponpes, it becomes evident which waria attend out of piety and who clocks in to collect an interview fee only when a visitor has scheduled 
an appointment. The economic and the spiritual often overlap since kyai and ministers are often paid, but usually congregants are not. Although I sympathize with Nangka's position, I do not oppose the waria economizing their position, even as congregants, to a wider audience. In fact, I tell Nangka I think the ponpes waria should charge the major media outlets even more, and someone should be the liaison between the waria and the media. The ponpes makes for a bold headline: First Transgender School/Mosque in the World, but Nangka is thinking beyond a headline and is afraid others are not. "We need a program for the elderly waria who cannot work." Nangka wants to make the waria economically independent by not relying on funds from organizations or visitors which is not a sustainable source of capital. The responsibility of taking care of the older generation falls on children in Indonesia. Like many places outside of Western Europe and the US, there is no governmental social security system that can be a safety net for individuals that do not have family to rely on. For the waria, being a woman without a uterus, can be financial hazard.

\section{Gender Divide}

Nanas says one reason Islam focuses on a strong gender binary is because of inheritance laws. Although families can decide how resources are split among heirs, generally males receive double the portion of females. This system was a step up in Arabia since women inherited nothing in times previous to the Prophet. Perak tells me that she in fact received the female portion from her parents' inheritance which meant one half of what her brothers received.

Nangka describes how the medical establishment reinforces the gender binary by making the waria uncomfortable. She says doctors and nurses will walk into rooms and ask questions like, "Why do you look so feminine? You should cut your hair so you look more handsome. Do you know you are acting against your religion?" She thinks part of society's unacceptance comes from people thinking the waria do not pay taxes because they do not have formal jobs. "But from morning to night they pay taxes because they are buying things." Many waria do not have identification cards and the public thinks they get free medical insurance through the government. 
Nangka spends her time supporting the waria, but her goal is to get the waria community to support themselves even though it takes years. "The difficulty is making a personal problem a communal problem. For example, if a trans sex worker experiences violence from a customer, they consider this personal and do not want to make it public, but this is a communal problem that needs to be solved together." Nangka organizes what she calls small "cells" because there has been a rise in attacks on LGBT people in the last three years. "By cell I mean small organizations, so if one is attacked we still have others." She says there is a division in the LGBT community. "We have meetings together and at first the waria think the gays do not like them, and the gays think the waria do not like them, but then they talk to each other and they no longer think each is abnormal." The LGBTQ moniker as a monolithic community has always been a misnomer and Nangka is affirming this is even more true in a gender segregated society.

Although ustedz Moshere identifies as Salafi and does not supports the waria, he also does not support their mistreatment. "If the waria have a good intention to pray at the mosque, then people should not give them bad treatment, their ignorance about how to treat the waria should not be tolerated." He also sees the government as having a role in the proper way to handle the waria. "It is the responsibility of the government to train the waria so they can work legally." He suggests the waria can work through online businesses or through long distance interpretation and translation work, all privatized spheres that don't require visibility and can be done through an Internet connection. I remind him that the resources to marshal such an enterprise are not in reach for most of the waria community, and the educational and fiduciary capital to be an entrepreneur is great. "This is where the government should take responsibility," is his response.

\section{Waria Language}

Themes of safety, health, beauty, money, love, work, sex, and piousness surface as important areas of discourse for the waria. Part of that discourse is in a language called bahasa waria, with the word "bahasa" translating as "language." Hitam tells me that Bahasa Waria is a shared lexicon that communicates a waria subject position in a tongue that outsiders will not 
understand. This secret language is not unlike the use of the argot Polari in the United Kingdom which was used by prostitutes and a gay subculture up until the $20^{\text {th }}$ century. If daily calls to prayer link the Republic of Indonesia to a national aural space, the waria's specialized vocabulary links them to a wider archipelago of other waria. The language known in English as Indonesian has been used by the region for centuries as the tongue used for trade. Although its provenance is from the island of Sumatra, it was known as Malay. The Dutch did not want their territory to learn Dutch, so they chose the lingua franca of their colony, Malay, to communicate among the hundreds of ethnicities. ${ }^{17}$ The waria will not only use their furtive tongue to divulge their latest fancy, but they use it to warn their friends of police raids or danger.

Delapan does not have to worry about police raids since she usually uses social media to set up her appointments instead of the usual pick up place: the train tracks. Facebooking is an ever-popular technique to avoid danger and negotiate a higher price. She can attract clients with her beauty that has come through multiple injections of silicone in her face, buttocks, and breasts. "I'm actually not a transgender since I already changed the shape of my body. I'm a transsexual." This is the first time an informant has self-identified with the label transsexual because of their body modification. Delapan's tone suggests she is aware this is a technicality. Since her organizations' objective is to increase awareness of gender and sexual minorities, Western models have become integrated into Delapan's lexicon, as has Jogja's dialect of Bahasa Waria.

\footnotetext{
${ }^{17}$ Boellstorff, A Coincidence of Desires, 121.
} 


\section{CHAPTER FIVE: WARIA RITUAL PERFORMANCE}

The waria are marked as waria because of dress, makeup, and body modification. It is clear they are not trying to assimilate only as women, but they are ostensibly standing out as a different type of person. Even the waria that put on the male garb and wipe off their makeup inside the pesantren do not see their waria-ness diminish in any way. There are two themes that emerge within waria subjectivity: sexual desire for men/maleness and desire for one to be female/femaleness. These dual desires can be interpreted as moving the waria in between (i.e. transing) male and female, or it can be seen as separating them into a category outside of male and female. When I asked my informants about their gender identity, most identified as waria. When I asked about their sexual orientation, most identified as heterosexual. When I asked how they pray, most answered as men. When I asked how they wanted to be buried, most answered as men. These sexual, gender, sex, religious positions do not align into a coherent person as it is conceived from a Western perspective, unless we see how the waria contextualize their gender. For example, Even though Kuning knows about her mom's, that is Perak's, body modification, Kuning says, "God created mama as a man and it would be a sin if she was buried as a woman--I heard this at school." I ask Kuning what makes a man. "A man is someone who loves a woman and is brave." Again, the dual side of a heteronormative coin, male genitalia coincides with sexual desire for something different. And since what makes a "woman" is the erotic desire for a man, so Kuning sees her mom's waria-ness as an everyday lived reality, but in a religious reality, her mom is a man (even though Perak is the only informant that said she wants to be buried as a woman).

Perak, like all my interlocutors, refused to accept that they were less pious Muslims than their neighbors who did not have to challenge the dominant gender classification system that emerges from religious, colonial, and post-colonial discources. The waria do not only challenge the secular state's heteronormative systems, but a traditional Islamic system that encompasses the scriptures of the Quran, the teachings of the hadith, the rulings of figh, and the orthodoxy of sharia. This fourfold force creates a regime of power and knowledge, to borrow Foucault's words, whose purpose is to replicate the social order. The waria disrupt that order, and nothing threatens 
religious institutions more than disorder. The waria have an internal disposition that includes sexual orientation and gender identity; they all say they are heterosexual and waria. This is an instantiation of the waria replicating the dominant sexual binary, while resisting the dominant gender binary by asserting a different subject position. The pesantren waria is a progressive project within the Javanese city of Yogyakarta, within the archipelago state of Indonesia, and within the vast religious canopy that is Islam that both replicates and resists the sexual and gender binaries.

On May 27, 2006 a large earthquake occurred 12 miles Southeast of Yogyakarta resulting in significant loss of life and injuries. It was this disaster that spurred the creation of a space where the waria could gather in a religious context. A 48-year-old waria called Lima was so moved by the suffering she saw after the earthquake, with five waria dying in Jogja, that she invited her friends from surrounding cities to join her in a prayer service led by an Islamic leader called Kyai Haji Hamroli. Kyai Hamroli passed away in 2012 and Bu Lima died a month before I arrived in Jogja, so I was unable to directly obtain details from the two founding leaders. From this waria prayer meeting in $\mathbf{2 0 0 6}$ grew the idea that there could be a place for the transgender community to learn Quran, hadith, Arabic, and how to pray comfortably and correctly. The community had to decide how this new space would function and what it would be called. For political and social reasons it was decided that this new prayer and teaching space would be called a pesanatren waria, literally translated, residential-religious-learning-space-for-male-tofemales.

The ponpes is sometimes filled with more volunteers and student researchers than waria participants. Master students from nearby universities such as Universitas Islam Indonesia and Universitas Islam Negri volunteer their time one or two times a week to guide the waria. Many come to the ponpes for a school research project and decide to continue their engagement with the ponpes as a volunteer.

In designing this thesis, I sought to understand my Indonesian informants who were members of the pesantren waria al-Fatah which which can translate to "The Opening." 
Furthermore, I sought to comprehend the larger waria community, and members of various Islamic schools of thought inside Jogja. I wanted to know how Islam animated their behavior in their private and public life, and how Islamic spirituality structured their beliefs and values. One of the contributions of this study is to demonstrate that Islam can clearly go beyond an ethic of tolerance to accommodate a diversity and acceptance that is life giving.

The waria and the pesantren are delightfully problematic phenomena that stretch our concepts of what it is means to embody an individual, social, and national identity that don't always share the same vision. The waria must weather current social stigmas as well as the fourfold Islamic force previously mentioned: Quran, hadith, fiqh, and sharia. "This is not an easy life," as I was told by many of my interviewees, and indeed it is not.

There are many Islams and there are many types of warias. This study's angle of vision reveals the spiritual and social life of 19 transgender Muslims living in a diverse community on an island in the Indian Ocean. I was located in what many consider to be the most intellectually vivacious and culturally diverse city widely referred to as "the city of tolerance." By focusing on one community within one city, I am putting into focus a small diachronic slice of reality with complex political, juridical, spiritual, educational, and relational dynamics that are not present in other areas of Java, let alone the wider archipelago. Most obviously, I am eliding the experiences of female-to-male transgender Indonesians because it is beyond the scope of the current study. This writing is further limited within the genre of an academic thesis for a public research university addressed to a scholarly audience. There are intimacies, friendships, conversations, comportments, and names that will be left out of focus to protect and respect my informants and comply with Institutional Review Board guidelines. As writers, we select and emphasize in order to create meaning; I want to include that which acknowledges the humanity at the core of this enterprise. Tujuh remarked in response to my clumsy question, "Do you identify as male, female, both, neither, or in between?" "I'm human-it's enough for me."

It was a gift for me to hear those words because it reminded me that although I was dividing up reality, as academe trains one to do, I do not have to get trapped in believing the 
divisions, that the boundaries are real. Categories of analysis are frames that can be helpful; they can also be enervating. The vitality of a living entity is often annihilated once it is dissected. The science of anatomy, the Greek word literally meaning to "cut up," can only see the structure of life, not the living entity. I endeavor to uncover the function and production of performed identity through the art of analysis, from the Greek word "analysis" literally meaning to "loosen up." I aim to loosen and unpack the meaning making practices the waria community enacts in order to promote life-enriching dialogue, not life-denying dissection.

I suggest that the pesantren waria community employs Islam as a resource in the resolution of marginalization under patriarchal regimes. To suggest this is to use words that at times may seem concrete and stable. I use words, groupings, and categories such as gender, transgender, and sexual attraction/orientation not because I propose there is an essential ontological connection to them, but because flexibility balanced with rigidity allows life to flourish. If my desk did not have a stable, inflexible wood top, I would not be able to type this. I want to communicate clearly and include gender and sexual minorities in the reshaping of a more just and accepting world. The value of this case study focusing on the pesantren waria takes what could be an abstract notion of gender fluidity and Islamic theology and grounds such ideas in the nitty-gritty of life. Scott Kugle declares, "Islam, after all, has no voice. Only Muslims have voices. Only they speak in the name of Islam, and Muslims speak from distinct social and political contexts that shape how they practice and represent their religious tradition."1

\section{Pesantren}

The establishment of Islamic educational institutions in the 1800s came after the fall of Indonesian Islamic kingdoms in the 1700s with the advent of European colonialism. Pesantrens or Islamic boarding schools became well known on the island of Java. According to Burhanudin, the pesantren consisted of a "mosque, a boarding house for the students, and a house for the

\footnotetext{
${ }^{1}$ Scott Alan Kugle, Homosexuality in Islam: Critical Reflection on Gay, Lesbian, and Transgender Muslims (Oxford, England: Oneworld Publications, 2010), 20.
} 
ulama [scholars] or kyai [head teaher] and their families." Islamic sciences and religious practice was taught at these institutions making the kyai or religious leader an important figure who interpreted what was orthodox and heterodox in Java. This kyai was even more revered if they had studied in Mecca.

Urban development accelerated in Indonesia during the $20^{\text {th }}$ century and with it came modern education that focused on secular subjects. This in conjunction with the colonial Dutch government's "ethical policy," that is, the Dutch's turn from seeing Indonesia merely as a profitmaking colony to one where the residents welfare and education were deemed valuable, were central causes for an Islamic reform movement. This social welfare movement emerged in Java most ostensibly in 1916 with the Muhammadiyah movement that sought to purify Islam of nonMulsim influences and create modern educational institutions that would demote the pesantren and the ulama or religious scholars they housed.

In response, the ulamas established Nahdlatul Ulama (NU) in 1926 to "maintain the religious authority of the ulamas in the midst of threats from the reform group." ${ }^{3}$ The reformers, the Muhammadiyahs, emphasized a return to the Quran and capitalized on the colonizer's printing presses thus publishing books and newspapers. NU saw this reform as threatening their authority along with the information that could suddenly become available in bookshops and libraries. Nonetheless, NU gradually reformed its pesantren pedagogy from a religion only curriculum to a mix of secular and religious subjects, what is called a madrasah.

Perhaps diverse religious expressions such as the pesantren waria is an extension of the openness that followed the collapse of the Suharto regime in 1998. Like all religions, Islam has been used to justify violence and rebellion against the state, while others have used Islam to support pluralism. Although Indonesia is about 90 percent Muslim, it is worth noting that all citizens must register as one of six official religions. Some religious minorities such as Bahais or Buddhists will register as Muslim because they do not wish to be known as a minority faith. One

\footnotetext{
${ }^{2}$ Ibid.,14.

${ }^{3}$ Ibid., 28.
} 
informant told me his father has been unable to get a promotion in his government position since it is known that he is Christian.

It is usually assumed that the modernity of city life is less pious than village. The waria go against the grain of this assumption by showing how the metropolis has allowed them to become more pious. There are approximately 250 million Indonesians with about 225 million being Muslim, far greater than the 28 million inhabiting Saudi Arabia. The archipelago has used its network of 30-thousand pesantrens to create the largest system of Muslim education in the world. Most of these boarding schools are in rural areas where pesantrens become not only centers of learning, but of power, piety, and status. Indonesians primarily follow Sunni Islam under the Shafii school of law with popular devotion to Sufi orders precipitously falling with the early $20^{\text {th }}$ century. The organization Nahdlatul Ulama (NU), literally translated as the Awakened Scholars, was founded in 1926 and has around 80 million members. ${ }^{4}$ The creation of NU was in reaction to the anti-Javanese sentiment embodied in the 1912 founding of Muhammadiyah, an Egyptian influenced socio-religious institution whose aim was to purify Islam of pre-Islamic influences and highlight individual interpretation (ijtihad) of the Quran. It is estimated that there are 40 million members of Muhammadiya which was birthed in the city of Yogyakarta, near the pesantren waria. While studying at Gadjah Mada University, my professor and world authority on Indonesian Islamic thought, Martin Van Bruinessen described how the pesantren system grew out of a $19^{\text {th }}$ century practice of individual kyais gaining a following of students that would frequent the kyai's home for edification. Formal religious education developed out of this model until modernization brought secular and religious subjects together in the pesantren.

After Bu Lima passed away from complications with her kidneys, her best friend, Perak took the helm of the ponpes and emerged as the next waria leader of the religious community. The pesantren was moved from Lima's rented house to Perak's owned 1896 house in an old area of Jogja called Kotagede, next to the old Sultan's compound that to this day depicts Hindu deities on the outside walls. This is apropos since Perak chose the name of a Hindu goddess as her

\footnotetext{
${ }^{4}$ Smith, Bianca and Marc Woodward, Gender and Power in Indonesian Islam : Leaders, Feminists, Sufis and Pesantren Selves, 5.
} 
moniker. All waria decide upon a new waria name to live with after accepting their gender identity. Perak was the only one of my interviewees that chose a religious name, and one that comes from the Hindu epic the Ramayana which paints a figure of the goddess Perak who embodies the best of wifely and feminine virtues. Shina told me she chose the name because "Javanese culture was influenced by Hinduism."

Perak is chair of a Waria Association (Ikatan Waria Yogyakarta) made up of ten different waria communities spread throughout the city which was created by the oldest non-governmental organization in Indonesia: Planned Parenthood. These communities usually comprise a few dozen waria living near each other and share a common activity such as art, volleyball, streetsinging, or prostitution. Perak receives daily requests for interviews by Indonesian university students, Western scholars, and journalists from around the world since the pesantren waria has been featured in magazines and television programs for the last six years. Her lexicon partially reflects her interaction with Western discourse communities.

Bu Perak is a 52-year-old woman who grew up in Jogja and has a complex understanding of gender. She holds a bachelor's degree in biology, an unusually high level of education for the waria community since most run away from school and home before graduating high school out of self-preservation. Perak is the only regular attendee at the pesantren that stands in the back of her living-room-turned-prayer-room during salat, the traditional place for women to pray. She wears the traditional body length white robe (mukenah) that women wear during the 5 quotidian prayers. This gown is worn even for solitarily prayer and covers all body parts except the palms and face. Perak is also the only member to consistently wear a hijab that completely covers her hair. She has a complex understanding of gender and appropriates some Western style discourse when articulating her view on the subject. "A waria is a woman trapped in a man's body," she told me when asked to define the word waria.

There are 335 waria living in the city of Jogja according Perak's registry from the Waria Association. With 35 official members, and 5 regular attendees at the ponpes, most waria are not participating actively in this religious space created directly for the community. "Most waria forget 
their religion-they are busy with their gender," Perak tells me. I notice that most of the waria that attend Sunday and Wednesday afternoon classes at the ponpes are between 40 and 60 years old, so I ask about this generational divide. Perak says, "It is normal that only the old generation think about religion—-the young are busy making money and having fun."

Emas seems to be second in command at the ponpes. She is 58 -years-old and says she was physically born as a man, but feels like a woman and has since she was 4-years-old when she wanted to wrap a towel around her breasts after bath-time, unlike her brother. One reason that scholars have not agreed on the waria's gender is because it is malleable in visual ways. The most surprising phenomenon about observing the waria is that they contextualize their gender depending on where they are, who they are with, and their purpose for being in a certain place. For example, at the pesantren waria, a waria may come to the ponpes dressed as a woman and take off all her makeup and wig to perform ablutions. She will then take off her feminine attire to don a sarong and paci, or masculine hat, and stand in the men's section of the prayer room and conduct the proper prayers required of men. This was jarring to me since I could not understand why all the waria except one or two would pray as men during formal prayers (salat), but act as if a woman outside of this ritualized space. As Satu told me, "the waria don't arrive at gender" in the same way many Westerns think of what it means be trans. The waria I spoke with did not feel any inconsistency in being feminine in the public sphere and performing as masculine in their private, religious sphere: an inverse of what many trans people in the West experience. Many (male-tofemale) Americans will continue to display a masculine appearance in the public sphere out of of social, religious, and economic reasons, while taking on a feminine expression in private where they will not be stigmatized for their transgression of gender norms.

One of my informants refused this public/private distinction. I met Tujuh at a popular tourist restaurant in Jogja called ViaVia. I got in touch with her after I noticed ViaVia display Tujuh's portraiture artwork on their walls. The portraits depicted a triptych Tujuh staring into a camera with the Indonesian national emblem backgrounded against a scarlet wall. The emblem is that of Hinduism's Garuda, a bird creature that accompanies Vishnu, and his wings give Tujuh an 
angelic aura making her look even younger than her age of twenty-something. One panel shows Tujuh standing in boots, boxer shorts, and a traditional Indonesian cap worn by men. The second panel portrays her in flip-flops, panties, and with long, black hair cascading down one side of her head. The last picture portrays Tujuh in high heels, ornate panties, and full make-up. These photographs externalize the transitions she lives out in her life: village life as a boy, mundane life as a waria, and the external performance of hyper-femininity for power or pleasure. The Garuda in the background also comments on the social plight of the waria; is the bird behind her coming to devour her or raise her up?

Tujuh orders a coke and spaghetti for breakfast and sucks down a few Indonesian cigarettes known as kreteks, a mix of tobacco and clove. She is not part of the ponpes, and she let's me know she's critical of the project since it is not a "real pondok pesantren." All of her critiques are accurate: there is no set curriculum, there are no permanent teachers, there is no elaborate organizational structure, there is no group of students living in one facility. The pesantren waria is a pesantren in name only. This is not a secret. "The activities at the pesantren are ceremonial, it is just someone's house and the owner is transgender, but l'm proud of her [Perak] because she shows the existence of waria." The ponpes is Perak's house and their activities are akin to what Americans would call a Bible Study. But the rhetoric of the word "pesantren" draws on a logos of religious legitimization, an ethos of a kyia, and pathos of the public to grant respect and acceptance to the waria's pious project. But Tujuh isn't interested in this spiritual space because "the transgender problem in Indonesia is not religion, it is about education which is needed to get a good job. Many waria only go to elementary school and then work as sex-workers or street musicians (pengamen)." Her father is an ustadz who sent her live in a pesantren for fourteen years. She perks up describing how she made waves questioning the logic of her religious teachers:

Tujuh: I found a paragraph in the Koran that said, 'He left his wife and met other men.' Met in this context meant sexual intercourse. My question was simple-this man was married and had sex with other men. If I am not married and do not desire women, how can this negative verse apply to me?" I asked the imams, what gender is your God? And they said, 'God is not a woman and God is not a 
man.' Then I stood up and said, 'I am your God.' It made people want to kill me, but it made me happy being a troublemaker, to make people think.

David: Do you consider yourself man or woman, half man half woman, something else?"

Tujuh: I'm human. That's enough for me. If you consider me a woman, okay. If you consider me a man, okay, but that's not my problem; it's yours.

David: What is a real man?

Tujuh: Someone who can hold his words, not his genitals.

David: What do you think about genital reassignment surgery?

Tujuh: Maybe some waria want this, but if you're a prostitute that would be crazy because you will get much more money if you have a big dick, customers like that.

Tujuh is referring to the practice the waria have of penetrating their clients for money. I did not gather enough information to quantify how much pleasure is derived from this and for what reason, but the fact that the waria want to keep their phallus (and pray and die as a man) confronts the Western idea that gender is an arrival or a totalizing category that means one is to inhabit a proper gender norm constantly. Martin Manalansan in his ethnography Global Divas speaks of Filipino gay men in New York who resist the monolithic representation of "global gayness" ${ }^{\prime \prime}$ and teleological narratives of LGBT liberation by not conforming to the white, masculine gay ideal that he sees portrayed. In a similar fashion, the waria who have moved from the village to the modern city have resisted assimilating into a totalizing process of always presenting a continuous gendered subject position (femininity) in every context in order to be their "true selves." The warias very presence (and modified bodies) contests conservative Islamic discourses and national ideals of the male-female binary, and at the same time, their playback of femininity replicates such discourses.

\section{Prayer}

There is a level of dis-identification of femininity for the waria when they wipe off their makeup and put on traditional male clothing to pray: sarong and pachi (hat). When I first began attending pesantren activities, I was most surprised to learn that most of the waria expressed themselves in a masculine manner when it came to prayer. Some waria enter the pesantren in their feminine attire and will leave their makeup and feminine clothing in tact if they do not engage

\footnotetext{
${ }^{5}$ Martin F. Manalansan, Global Divas: Filipino Gay Men in the Diaspora (Durham: Duke University Press, 2003), 6.
} 
in prayer, but most will take on the masculine-gendered role for prayer. This does not re-identity the waria as men to other waria, though it may with some ustedz (religious teachers), but it does express a masculine identity temporarily. My interlocutors maintained that their masculine roles do not lessen their female-ness/waria-ness to each other; however, they are aware they must reorchestrate a credible femininity once their prayer is over and they enter the public sphere. The waria's gender performance is instrumental to their religiosity, and it seems there is a pleasure washing away the makeup to stand piously in front of God. As Perak, the leader of the pesantren waria, noted to me about why she keeps her makeup on when she prays and her friends don't, "They don't celebrate their waria-ness to Allah." Emas has been part of the pesantren waria since its start in 2008. She grew up in a Muslim family in North Sumatra, but has been in Jogja for almost forty years. She self-identifies as a transgender female and says she knew at a young age she was a girl, but did not start dressing as one until her first year of high school. Part of what motivated her to join the pesantren was how uncomfortable men in the mosque would act when she joined their line to pray. "I dress up as a man, but inside me, my heart, I am a woman. If I pray, I will dress as a man, but this is just outside appearances. I have friends that wear mukenah [feminine prayer attire] and that's their choice." A common pattern for my interviewees revolves around growing up in a small rural village where they prayed out of expectation or choice, and then fled to cities where it became difficult to pray because if a waria enters a urban mosque dressed as men, they don't feel welcomed or accepted like they did in their hometown. "People would stare with no respect at all, so I would just go on a holy day like Idul Firti," Emas remarks.

Hitam says her village accepts her as a woman since they ask her to cook, prepare snacks, and clean instead of working with the men. Hitam does most of the cooking for the ponpes. I have never seen her pray although she likes to tell researches she does. If I ask her why she is not praying in the musollah (prayer room) of Perak's house, she will sarcastically remark that she is menstruating. Hitam joins in all the social activities of the ponpes while chain smoking and making fun of all the foreigners (bule) that traipse through her home. In fact, Hitam regularly fabricates information for those that are interviewing her out of what seems like a 
combination of weariness, playfulness, and economic opportunity. She can ask for money if somebody wants to interview her and she seems to say what she thinks others want to hear. Hitam is rehearsed in her formulated responses about how she has learned to pray correctly, perform the proper bodily cleaning rituals (wudhu), and read the Koran. She does none of the above and gives me dirty looks and mumbles words she knows I can't understand when I point this out.

Curiously, Emas identifies with a female gender identity and has a masculine gender expression during ritualized prayers, and Perak identities as in-between a man or woman, or as a waria, and has the most feminine gender expression inside the ponpes. In the West, the term "cis-gender" is used to refer to a person whose gender identity and biological sex is in alignment; however, the waria can complicate this notion of alignment since they can align differently depending on context. Even with Perak's less-than-female gender identity, she took the rare step of registering for a sex-reassignment surgery when she was younger, but never went through with it. She did have plastic surgery to construct breasts and reduce her Adam's apple in 1989. She says she knew she was waria when she was 8-years-old and began wearing girls clothes upon entering junior high.

Since Perak is the only regular who prays as a woman, I ask why she thinks other members of the ponpes do not? Almost every interlocutor I asked quickly answered the question with a trope of ease. "I'm most comfortable that way," was the usual response. Perak had more to say: “It is because of culture's influence and they don't want to lie to God when they pray to him. I don't think they have enough confidence." Perhaps because of the relationship I cultivated with Perak over a two-month period, she offered more than the usual comfort explication. Perak immediately went on to talk about how some families reject a child if she is waria, or some waria fear not being accepted by their families. She drew a line connecting the waria's perception of being authentic before God so the waria's prayers are heard, and being authentic before family so they are accepted. In Perak's estimation, the value of acceptance is the most sought after value for her community. The Lockean liberal self that grounds notions of independence in the 
West seems to be modified in Java where the self extends to encompass family members, even if they are not present such as in the ponpes. Acceptance is connected to authenticity and legitimacy of authority, a subject will we turn to in the chapter six as we examine Islam's place in Indonesia and its impact on gender.

Putih also prays as a man and grew up in a Muhammadiyah household going to a mosque every day and a madrasah, or Islamic elementary school, for two years. She was in fourth grade when she realized she was attracted to boys and says she had a relationship with an ustadz's son. At the age of 20 , she left her home and became a sex-worker. I ask if anyone ever tells her that being waria is against Islam. "Yes, some say to be waria violates God's will, but I say we don't know whether God is a man or a woman or waria." It is logical that the waria find solace not by referencing the Prophet's gender, but Allah's genderless state as the supreme diety. Religious followers usually try to replicate their founding figures behavior and this is especially evident with the Salafi movement which is an Arabic word meaning "predecessors". Salafi ideology points to an overt looking back to the first three generations of Muslims in the seventh century. Many waria framed their gender and spirituality in terms of a human being in relation to God, a looking back past the last prophet to the beginning of God's creation.

Putih references the notion of originality when I ask her about why she prays as a man; "because I was taught to pray like a man since I was a child using a sarong, and when I die I want to be buried as a man even though I am waria. I will be asked by God what is my orginal name and I will use my family name. This name will also be written on the tombstone." She remembers how she used to frequent mosques and stand in line to worship, but "people disgraced me because I was waria. I wore a sarong and hat, but I walked like a waria. Since I was a child I was taught to pray as a man and I don't want to change this. Additionally, my family told me not to change the way I pray even though I am waria." With a nod to her relatives and to God, Putih follows the pattern Perak said: the waria will pray as men because they want to feel accepted by their faith and family. 
Merah takes off her makeup before she prays. "I do what a man should do before praying because I have male gentials." She thinks those waria that pray as woman do not have a substantial enough understanding of Islam. Merah seems just as confident as Perak, and insists that the Quran and Hadith require her to take off her makeup before salat. She is open-minded and hesitantly defines even what a waria is since she stresses how important it is to look at a plurality of perspectives before attempting to declare any reified identity, and yet she avers that the waria that pray as women do not have a deep understanding of Islam and are not following the rules. It appears that if gender identity and sexual orientation are more closely linked in Java, biological sex and gender expression in a religious context are more closely linked as well.

Merah has lived in Jogja since 1987 and says she spoke with Lima about creating a spiritual space for waria starting in 1992. She is 53-years-old, hails from the island of Sulawesi, and is part of the Bugis people who are known for their five genders: man, woman, transman, transwoman, androgynous shaman (bissu). ${ }^{6}$ "We wanted to make the pesantren the core of our waria empowerment," she explains to me, "because of my history I know about the bissu who are different from the common waria. They have a religious perspective and are asexual where they don't think about sexuality—just old Bugis traditional beliefs. The community believes they mediate between God and humans. Based on this history, the waria can be much more significant if they are empowered to improve their spirituality. They don't have a good understanding of their religion, Islam, because they don't have access to education." Merah is convinced the Javanese waria can draw on the spiritual capital of the ritual specialists of her home island to better their plight in life. It seems the waria are unaware of the position they once held in the court of the Yogyakarta Sultanate as Tiga described since Islamic discourses have overtaken the purity the waria once were seen as embodying.

Delapan explains that worshipping in the ponpes "is more comfortable than the mosque nearby. I can pray with my waria friends without feeling unpleasant with our surroundings, but I try to make myself sure that I can pray anywhere as the mosque belongs to all." She explains that

${ }^{6}$ Sharyn Graham Davies, Gender Diversity in Indonesia: Sexuality, Islam and Queer Selves (New York: Routledge, 2010). 
she prays as a man so she does not stir up controversy in the mosque. But Delapan also always prays as a man in the ponpes where there is no controversy. She stresses how the male or female uniform is not so critical, but how one communicates and worships God is central. I keep a curious look on my face to show that I want to bury deeper into this issue because the waria will dismiss the importance of attire when it comes to performing prayer, but find gendered clothing severely oppressive when it comes to a work environment. "I have never worn the mukena, maybe because of my religious background as a kid when I got a strong doctrine that remains with me until now. I don't routinely pray anymore, but the teachings are still my guidance. I also want to avoid discrimination. First, if I don't disturb those in the mosque and create discomfort, then they won't discriminate against me." It makes sense that Delapan would want to blend in at her local mosque as a man, but her reason for continuing to pray as a man at the ponpes is because of "doctrine."

Enam is unique in that she does not feel comfortable praying as a man but does so "because God created me as a man. I am feminine, but I don't want to break the rule, so I pray as a man." Enam performs her prayers (salat) at home since she has gone blind in the last year as a result of a virus infection. She lives with a community of street singers who look after her, and I'm visiting her because she is Tujuh's neighbor. "I am waria in life now, religion is for my futureafter death. I try to get closer to God." Enam is in her early forties and prays five times a day though she is not part of the ponpes. She came to Jogja a few months ago to access medical attention for her eyes. She confesses that she does feel like she is in a dilemma. "I am not comfortable being a man, and being waria is not allowed by my religion. In the Quran, it is not allowed to be a waria, but I don't want to blame my heart that leads me to be a woman. This is God's secret. I was born a man, but I have a feeling that I want to be a woman." There are two spaces where Enam expresses herself in a masculine manner: in prayer and in her home village. Her motivation matches the others, "I want to respect my family; I don't want my neighbors to insult my family because of me." This is also why she wants to be buried as a man. No other waria besides Enam have told me they think the Quran does not allow a waria subject position. I 
ask her to be more specific about what being waria means. "For example, when I see a beautiful naked woman, and if I would be given all the money in the world to have sex with her, I wouldn't be able to. But, if I see a man, even if he's ugly, I would. Enam confirmed what others indicated, gender identity for my informants is an assemblage of sexual orientation, gender expression, and biological sex. I suspect she is highlighting sexual desire in her mind when she refers to the dilemma she feels between her faith and her waria status. She says people think "we are disgusting and stupid, but due to a lack of acceptance it is difficult for us to find jobs." Enam confides that she has been depressed, even terrified, since she is confined to her room while she seeks out alternative therapies for her vision. She is considering joining the pesantren waria for both spiritual and temporal reasons. She censures both her waria community and society for a lack of acceptance. “The ones who don't accept us are those who are lacking social scope; they have never left their comfort zone and have no desire to learn, so they will live in their ignorance. However, society is not the only one to blame since there are insensitive waria who cannot impregnate society because they are aggressive, wear revealing clothes, and disturb others."

Blewah volunteers his time at the ponpes and does not accept the waria who don't pray as men and act as men outside the pesantren. He was the first leader I met when I began joining the Sunday afternoon Arabic and Quran lessons. He is in his early twenties and I met him at a mosque he attends near a rice field on the edges of Jogja. He caught me off guard when he began the interview explaining his reasons for wanting to make the waria good Mulsims.

"Learning about Islam is one step toward changing them back into men; it does not have to be instant, the process can take a long time." I can't believe what l'm hearing. Perak was clear that all the volunteers at the ponpes must be supportive of the waria. Blewah explains:

I do think the waria have the same rights as other people so my friends and I want to change the mindset of people. They need a friend to communicate with; if they don't break laws, consume alcohol or engage in homosexual acts, and practice the religion, then Islam has nothing against them.

David: Do you think of the waria as men or women?

Blewah: I think they are men.

David: Why?

Blewah: I look at the teachings of Islam. If you are born male, you have to pray as male. They can have feminine tendencies, but they cannot stop being their 
original sex. Their actions can vary in relation to other people, but not in relation to God.

David: In the pesantren they can choose to pray how they want.

Blewah: For now, but step by step I will try to switch their mindset. Islam does not require you instantly change by force.

I'm surprised that Blewah does not know any Quranic scriptures or hadith relating to waria, but he says that waria go to a place in-between heaven and hell upon death. He emphasizes that his most important goal is getting all the members of the ponpes to pray as men, even if it means they are women everywhere else. He doesn't have much work to do since virtually all the waria do pray as men.

\section{Death and Burial}

Almost all the waria not only pray as men, they want to die as men. This is important, Emas told me, because if she was created as a man by God, she must return to him in her original condition even if she gets "involved in a woman's world" during the in-between state of birth and death. The waria also noted that they must be buried as men because their masculine name will be called out when their corpse is being washed before burial. This is reminiscent of David Reimer asking what his masculine name was upon finding out he was born with male genitalia. Naming is an exercise in power and one that is foundational as we see from the biblical story of Adam naming the creatures of the earth in the book of Genesis. Calling out a name place, person, identity, idea, asserts agency and establishes what is and what is not. The very epithet "waria" was created by the Minister of Religious affairs in the late 70s. What is named is foregrounded, while what is not named is backgrounded. Articulation, enunciation, or a chain of citations creates what is reality whether that be a woman's world while on earth or a man's body upon death.

Perak comes from a Muhammadiya family and says they were not fanatical, but the movement is "more puritanical wanting to bring Islam back to the pure teachings." She now identifies as part of NU because this religious movement "is based in Javanese culture." As a child, she attended a pesantren for three years with three of her waria friends, so she was trained to pray as a boy, yet she does not revert to habit as a source of comfort like the other waria. She 
also differs from the other 18 waria I interviewed in that she wants to be shrouded as a woman in death where she is covered in five pieces of cloth instead of the three pieces used for men, but she will allow her family to decide how the burial and prayers will be conducted. In other words, the family can decide to have the prayers in Arabic include masculine or feminine pronouns. Perak is expressing that in death, she wants her gender expression to continue as it is in life, as feminine, but others can verbally express about her as they like. Perak is an outlier in her crosscontextual desire to be read as woman/waria in this world and the next.

When Oranye comes to the ponpes dressed as a woman, I notice she does not pray, but when she isn't wearing her make-up she does. Oranye tells me she was determined to finish high school and saw how some waria peers quickly dropped out of school after attempting to dress as girls or apply makeup. "I was sexually attracted to my male friends and I found comfort in dressing as a woman although I didn't tell my family until I was 27-years-old. My mother told me, 'I am more okay if you dress up than if you become a thief."' Oranye repeats what many at the pesantren have said: God cares about good deeds, not if you are a man or a woman. But, she still wants to be buried as a man being wrapped with a kain kafan (shroud), her male name written on the gravestone, and her brother taking care of the body. Focusing on gender identity, I tell Oranye I am confused why almost the whole community wants to be buried as man when they go through life preferring to be identified as a woman. She quickly corrects me, "I am waria, not a woman. I have consequences here as a waria even though I wear skirts and apply make-up. I was born as a man; I want to be buried as a man too." It is difficult for me to understand how she can compartmentalize herself into man-ness in death when she will spend her life thinking of herself and having others think of her as having more waria-ness/woman-ness. I am seeking a congruence of identity and behavior while the waria are seeking a congruence of identity and behavior based on context.

Biru refers to a kind of continuity when she says "we were born men, so I want to go back to that time at death." If I am seeking consistency from life to death, Biru is pointing to a consistency from pre-life to death or how one enters this world is how one exits. Biru attends a 
Catholic church, her rituals are not gendered like they are in mosques; she does not have to choose between a masculine and feminine binary system of expression since she can be waria/woman during religious services, but she will be dressed and named a certain way at death and she would prefer to die as a man. She says her family can choose how they bury her body. She doesn't reference God requiring her to stand before him in her original form, but she does imagine her family will call out her male birth name.

Ungu says she will be judged by her goodness, kindness, and merit when she dies. She is happy to practice Islam with her friends "who have the same destiny." People that don't share the same destiny with her, she recalls, insult her when she enters a mosque and sits in the men's area:

Ungu: I find other mosques where people don't know who I am and I can feel comfortable praying. Most waria go to masjids that are not close, where people don't know who they are. During one Ramadan, I had been reciting the Quran and praying and I didn't clean all my makeup off completely. I was wearing the sarong and kopiah and when I entered the masjid they started to whisper-I haven't felt comfortable since then.

David: Why don't you take a seat in the women's section?

Ungu: I have short hair.

David: Why not dress up like a woman and sit in the women's section?

Ungu: I don't want to be burdened with what I look like or dress as-I want to pray to God. And I don't dress like a woman because I have to be clean. We have to do ablutions so our prayers are valid.

When I bring up gender and death, Ungu's definition no longer orbits around gender expression; in a religious context gender is defined by biological anatomy. "I want to be buried as a man because I was born a man and want to return to God, the Creator, as a man. I've never seen waria, even Christian, not buried as men. Islam teaches that all human beings have to return to God as they were born." The contextualization of gender for the waria is really the contextualization of gender expression. Although the waria continually say they pray as men and will be buried as men, they also recognize the nature of their soul will persist and the external body is just packaging. In a sense, biological anatomy is like the feminine garb they wear, an external trapping chosen by God. Ungu uses her body since it was given to her, and her gender expression may change during prayer or upon death, but her identity as a waria and her attraction to men which grounds that identity does not change. 
"If we take a linear paradigm of gender, then we say the waria should be buried as waria upon death." Upon hearing Nanas's words, I realize that my desire to see a linear coherence of gender follow the waria from life to death was my angle of vision on gender identity, and this teleological approach speaks about my own assumptions of interiority matching exteriority. The conservative religious leaders I spoke to wanted the same type of coherence I was seeking, but a match grounded in biology and not identity. The fluidity of the waria's gender expression was a wonderfully complex phenomenon to me, notwithstanding the religious oppression and social stigmatization that accompanied their lives. "But the only source where they can get the message they need to pray and die as men is from Islam because this is not from Javanese culture. There are references in Javanese culture for transgender such as Shikhandi." Nanas is referring to a character in the Hindu epic, Mahabharata, who was born a girl but was transformed into a man after performing austerities. Wahhabi Islam has created a discourse community that valorizes a binary understanding of gender, but equally important is the Dutch colonial paradigm of a patriarchial culture where women serve their husbands who head the family and the state. I will examine these discourses in the next chapter.

\section{Graveyard}

Delapan says that others will take care of her body upon death, so she will not be the one to decide if she is buried as a man or woman. "Of the fifteen friends of mine who are buried in Cikalan graveyard, they were buried as men, but waria friends unite to take care and bathe the one who passes away. No one has ever asked to be buried as a woman." The graveyard Delapan is referring to is one of the places we visited during our practice of nyekar, the traditional activity of visiting friends' and family graves before Ramadan to strew flowers. Many of the waria could not afford a kijing (permanent grave marker) because they are not cheap, so they are buried in unmarked graves that become hard to find. I notice that no one mentions HIV as a cause of death: accidents, old age, sickness, complications, but never AIDS. I ask Delapan about this. "If I say it's because of HIV without any proof, it would not be good. People feel ashamed; they are not ready for social judgment. For the sex-workers, if they have an HIV positive status 
and this was known, it would become a good weapon for her rival to make her customers refuse to have sex with her."

The religious leader or ustedz that accompanied the waria as they pilgrimaged to their friends' graves to offer prayers is a 35-year-old man named Arbei. He introduced himself to me as being native to Jogja and a public school teacher interested in assisting marginalized groups: convicts, street children, and waria. "There should be more people concerned about caring for outsiders," he acknowleges. "Big religious organizations like NU and Muhammadiyah have not been involved in this domain, and there should be a leader willing to be a figure for them. The waria have not been able to channel their interests into religion, and I want them to have equal rights." Arbei thinks the problems with the waria are more complex because it is so "out-of-thenorm."

Before Ramadan began, the waria rented a bus and spent a drizzly day travelling around Jogja vising the cemeteries of other waria who had died. Since most of my informants do not have blood-related family in the city, they pray over the graves of their friends. I was surprised to hear Putih tell me that she was praying so the sins of her friends would be forgiven so they make it into heaven. Putih said, "If they are in hell, we pray so their sin will be lightened." Perak said she is observing a Javanese ritual of spreading flowers and following the example of the Prophet Muhammad who visited his family's graves and offered palm leaves and prayers for the deceaseds' salvation. "I am not praying to them, but for them," Yunni informs me. She thinks this kind of pilgrimage to gravesites is an important reminder of the certainty of death, and to help her friends' sins be forgiven through prayers from those that are still alive. When I ask how it is helpful to pray for the dead, Hijau states, "Like human beings need to eat, the dead need our prayers." Her close friend died of AIDS and that is partially why she decided to skip work and offer prayers. Popular piety dictates, especially to NU adherents which Arbei is a part of, that visiting graves (ziyarah kubur) is propitious and best done before the fasting of Ramadhan begins. This tradition continues in spite of strong Salafi and Wahabi influences that denounce such practices as accretions that have corrupted Islam. 
Arbei leads recitations (dzikir), prayers, and says he tries to teach the waria "not to lie to themselves and God." He says the waria can decide what gender they want to be, but they "should decide on one gender and not change." I didn't expect to hear such an essentialist position wrapped in progressive discourse. "They can decide which gender is most right in their heart. If they pray as a man, they will buried as men."

Arbei recognizes that NU and Muhammadiya as having different methods and interpretations of religious observance, but believes a shared purpose of peace dissolves the conflict between the traditionalist and modernist ideologies. Indonesia's top clerical body called Majelis Ulama Indoniesia (MUI) which is a conglomerate of all of Indonesia's Sunni denominations including FPI is an entity Arbei has to contend with. The MUI was created in 1975 under the New Order regime to issue fatwa, or non-legally binding opinions, to make a synthesis of Islamic values and the nation's Pancasila philosophy. In July 2010, the MUI issued a fatwa banning sex-reassignment surgery. Arbei states, "I work with those who are the victims of MUl's fatwas. Their fatwas are textual instead of practical. I'm trying to make the waria comfortable with their religion and feel accepted." Arbei reinforces many of my interviewees' wordview: regardless of the text and one's interpretation, there is a transgender corporeal existence that struggles to survive. Arbei is alluding to Islam's theology of signs when he speaks of what's practical vis-à-vis what is textual. The head kyai of the pesantren was nodding towards this same concept that holds that signs (ayat) or that which is observable on earth is a type of argument for God's power and truth.

I asked Arbei to define what waria means. "Waria are God's creatures, physically men, but with different hormones. Men and women have different responsibilities regarding how they dress and what body parts are forbidden to see. Not everyone was created complete and the waria were created with a set of problems: hormones, instincts, disorders, so we cannot apply law that is for normal people." If I was listening to these words in the US, I would be cringing, but I feel grateful that regardless of his position that there is something incomplete or genetically disordered about the waria, he is working to bring about greater opportunity for them. I suspect 
this openness is influenced by some Sufi training and he tells me indeed it is, "my favorite Sufi teacher is Abdul-Qadir Gilani from Iraq. I learned about him in my pesantren in Krapyak." Krapyak is a large educational institution in Jogja known for their multicultural perspective and Sufism is what held sway for centruies in the archipelago before more conservative strains of Islam took hold in the late 1800 s.

\section{Destiny}

I met three Catholic waria that had a connection to the pesantren, but Biru was the only practicing Catholic waria that steadfastly participated in the ponpes schedule with the exception of praying and learning Arabic. She even joined her friends on their daylong pilgrimage before Ramadan to visit the gravesites of waria that had died. "I join out of solidarity; to pray for those that have died." She enjoys listening to the ustadz' homilies, yet her spiritual practice is going to church weekly. She mostly helps with dishes, clean up, and any chore that needs to be done to accommodate guests and friends visiting the ponpes. Biru is quiet, introspective, and a willing to lend a hand to anyone. Where Hitam is flamboyant, outspoken, and ribald at times, Biru is softspoken and warmly engages in conversation only when invited to do so. Although she is Christian, she tells me she comes because she feels "like a fellow sufferer under the same fate as the rest of the waria. I come to help since being a waria is my destiny." Biru seems older than she is; her silent stability and seriousness, match her outlook on life: "If you want others to respect you, you have to respect others first. Even if others hate me; I won't hate them back." Biru says there is only one God so it is easy for her to glean values from the pious milieu of the ponpes. The conept of fate in Arabic is called quadar and is considered one of the six articles of faith in orthodoxy since this tenet suggests that God is omniscient and knows all people's actions and desires. Such a concept is linked to what is known at the Preserved Tablet, that is, God has written down all this is and will be in heaven.

Nangka, who has been working at PKBI for the last eight years, wants to change the warias' views on fate and having a female soul. She oversees four divisions: street youth, female sex workers, gay/lesbian/bisexual, and transgender divisions. "We talk to them about HIV and 
citizenship," Nangka recites. She spends some of her free time at the ponpes because she loves the community and is a close friend of Perak. She tells me she regards the waria as male-bodied, "but I do not say that they are female because I do not agree that they are trapped in a man's body. I disagree with the phrase 'trapped in the wrong body' because it is not wrong. There is no problem with their body; the problem is with our mind; the construction of our mindset. They don't want to be what a man is constructed to be." Perak is one of the few waria I heard use the phraseology "trapped in the wrong body;" however, most other waria do wish they could be cisgendered. Nangka thinks the soul is genderless and wants the waria to get away from a preordained discourse because it distracts from people taking responsibility of how they perceive the world. "Sadly many transgender people think it's their destiny to be discriminated against. We have to make them wake up from this sleep. It's not destiny, it's a social construction that we have to fight. We have trainings to make them realize they have rights because they are Indonesian citizens."

Nangka says Javanese culture has changed since her grandmother's time. "My family is okay with sexual diversity because they are Javanese and think it is part of someone's destiny, to play the role of gay and transgender." She remembers her grandmother showed her a mantra that men-who-love-men are supposed to chant, and she asked her grandmother if such same-sex love is sinful. "Before it was not, but now it is considered," said her grandmother. Nangka mentions the Dutch code against homosexuality and how the Javanese would hide the Dutch colonialists who were being persecuted by the Dutch government under such penalizing statutes. "I don't agree that LGBT is a Western product; homophobia is the Western product."

After I returned to the states, Nangka was attacked in November 2014 at Yogyakarta's Transgender Day of Remembrance. Three mosques in the surrounding area called for violence to break up the remembrance gathering organized by the Yogyakarta Women's Network. Three persons, pretending to be police officers, targeted and assaulted six attendees with bamboo sticks. Nangka has not yet recovered. 
Religious leaders, such as my informant Belimbing, also look to fate as an organizing principle, but have a different interpretation. I sat outside Belimbing's brick walled house as he told me about his involvement with Muhammadiyah, "a proselytizing movement to bring Islamic teachings in line with the Quran and Sunna of the Prophet." I get nervous when I hear language of alignment because to bring the Sunna, or words and actions of the Prophet and align them with fiqh, hadith and the Quran is like bringing someone's gender expression in alignment with biological sex and gender identity; it is fictive since such abstractions are inherently unstable. In my mind, Belimbing's words background centuries of complex exegesis through a multitude of Islamic juridical schools of thought that don't agree on what correct Islamic alignment looks like. But I am not having a conversation with this professor to debate about theology; I have come to hear his perspective on Islam and waria. He tells me the waria are excluded from Indonesian society because of both culture and religion. He describes how they are perceived as bringing a disgrace to their family since they are thought as having a mental disorder. He says the waria leave their house at an early age to find community.

He explains the category of khuntha, and Arabic term that refers to intersex people, i.e., being born with ambiguous genitalia. But Belimbing says khuntha can also refer to those who are not cisgendered, that is, "those whose behavior does not align with their genitals." He says that if a child is born intersexed, one should wait to see which occurs first, a wet dream or menstruation, because which ever occurs first will decide the gender that must be chosen before adulthood. There are many assumptions about physiology and reproductive development in his statement and I wonder if Belimbing has ever had any personal experience with someone who is intersex. He says that outside of the category of kuntha, people cannot choose their gender because God determines people's "destiny and fate as to how they are born in this world" which in his mind is always within a male-female binary.

Hitam suggests she was created as waria and therefore is not doing anything against God. If the West grounds a determinism for sexual attraction or gender identity in physiological 
processes, the waria and religious leaders ground a determinism in the spiritual realm of fate. In Hitam's words:

The FPI or Muhammadiyah try to break up waria events like waria beauty contests. They don't support us where NU doesn't question us. For NU, it is just important that we don't destroy our morals. The FPI not only prohibit waria activities, they can be brutal and we are afraid. They have attacked us when we work at night and especially when the fasting month approaches. If we dress too sexy it means we are not faithful Muslim women. I dress appropriately and am more alert during Ramadan. They want to keep the holiness of Ramadan. We can be attacked by FPI or swept up in a raid by the local police. I am harassed by people who tell me being waria is a sin, not accepted by God, our prayers will not be accepted, and we will go to hell because we are neither man nor woman. If God had asked me before I was born, I would not have become a waria-I would have chosen to be a man or woman, so I think being waria is not a sin.

\section{Situated Performance}

If some Muslims view transgender individuals as ethically bankrupt or mentally ill, it is important to highlight the historic place of people such as the waria in the Islamic tradition. Indonesia is patriarchal society valuing masculinity and men above women and the LGBTQ community; a new fiqh is needed, as my informant Kyai Anggur maintains, if humans are to express the freedom and justice many see the Quran calling for. The waria are unique in Jogja since their presence and pesantren intimate a reform of Islamic beliefs and actions. The waria's Islamic response of a pesantren is compelling since it comes from inside a Muslim community vis-à-vis a secular institution with a progressive discourse. The waria are a challenge to both Indonesian and Western conceptions of gender as dimorphic with men seizing power at the cost of those lower on the hierarchy of value: women, children, and gender/sexual minorities. Investigating the dimorphic definition of gendered embodiment is the key to unpacking the complexity of gender and sexuality.

If gender is thought of as biological description, then we will be locked into a binary mode of thinking that contributes to shame, secrecy, and dangerous surgeries for those who do not conform to common physiology and psychology. The fixation on the biological body, in a sense, seems at odds with the religious emphasis on the soul's condition that will face the last Judgment and stand before Allah to determine whether paradise or hell will be the next abode. The Sufis, like all mystical spiritual strains, encourage not to identify with the body, but to dwell in the heart. 
The waria see their heart as residing in femaleness coupled with romantic desires for maleness. Their desires do not lead to procreation or even a clear category of gender. When Tujuh pronounces, "I am your God," after reasoning that God is neither male nor female, she is not only asserting her autonomy by being irreverent, but she is identifying with the non-dual Islamic conception of God and His quality of non-reproduction. Surah 112 begins with "Say, He is God the One, God the Eternal. He begot no one nor was He begotten." Moreover, Tujuh is challenging the social order that maleness is the apex of a gender hierarchy as has a long line of feminist theologians. ${ }^{8}$

Our gender in many ways is the bedrock of how we define what it means to be human. And since our existence is a mystery, we turn to myths to explain our place and being in the world. A word that has fallen out of use, "hermaphrodite," is offered to us from Greek and derives from the male god Hermes and the female god Aphrodite. This outdated nomenclature can be offputting since it focuses on genitalia that is assumed to be fully formed and evaluated as male and female. The term "intersex" is currently regarded as the most appropriate label. Although, none of my associates identified as being intersex, by their choice of hormone therapy, surgery, and silicone injections, they have achieved anatomical structures that are in between the form of man and women and thus implicitly argue for the mutability of gender based on physical form. Some of these body modifications may be new, but the patterns of feminine behavior in malebodied Indonesians have a long history.

The literature on Islamicate sexualities narrows in on castrated male servants known as "eunuchs", literally "bed-keeper" in Greek, and what Scott Kugle coined "emmasculine woman," that is, those woman that took of the garb, gait, speech, and behavior of men. ${ }^{9}$ Also, since South Asia has been privileged in academic discourse as a consequence of British colonization, the

\footnotetext{
${ }^{7}$ Abdel Haleem, The Quran: A New Translation, 444.

${ }^{8}$ Asma Barlas, "Believing Women" in Islam: Unreading Patriarchal Interpretations of the Quran (Austin, TX: University of Texas Press, 2002), 93.

${ }^{9}$ Kugle, Homosexuality in Islam, 242.
} 
category of hijra, or castrated males in Pakistan, Indian, and Bangladesh is a well-known phenomenon that is associated with transgender Muslims. Hijras are different from eunuchs since they make a choice to be initiated in a subculture of hijras as opposed to being coerced. ${ }^{10}$ And although these categories, along with the Arabian role of mukhannath or effeminate man, can overlap with features of the waria, there is no equivalence.

Religious leaders responses, as we have seen, to the waria range from literalisttraditional to conservative-modern to progressive-contemporary with differing ideas about what is socially needed, legally allowed, and spiritually accepted. The meanings humans impose on biological function and anatomic difference quickly descends into prescription rather than description. Patriarchal preconceptions have led to persecution of transgender people and, in the case of the waria, loss of family, education, income, and respect from the surrounding community.

There are stories in the hadith of the Prophet and his wives interacting with eunuchs and "once sold into Muslim households, the assumption was that they would become Muslim themselves and adopt the same moral duties as other believers." They were required to perform their daily prayers and "were directed to stand in a row behind the men but before the women. Their presence acted as a sort of human veil between the two genders, even in the mosque."11 This kind of gender separation does create a place for the waria, but at the cost of reinforcing and protecting cisgendered men's status as first and cisgendered women as last. This liminal space between men and women could be a jumping off point for the waria to assert their presence in a ritual context; however, I want to be careful not to conflate eunuchs and waria since the waria perceive themselves as a subject position based on an assemblage of internal dispositions orbiting around a female identity and sexual attraction to men. Although mukhannath most closely resembles today's category of male-to-female transgender Indonesian, historically the

\footnotetext{
${ }^{10}$ Serena Nanda, Neither Man nor Woman: The Hijras of India (Belmont, CA: Wadsworth Pub. Co., 1990).

${ }^{11}$ Kugle, Homosexuality in Islam, 252.
} 
mukhannath did not have access to synthetic hormones and did not define their subject position against sexual orientation as the waria do today.

In Indonesia, there is a tension between modernization and pietization with some political groups wanting to install sharia as national law and other groups wanting to push Indonesia into identity politics with a separation of church and state. The waria are a case that threatens the social order of hardline Islamists whose ideology cannot contain the incredible diversity of humans. The waria embody an Islamic praxis and doxy that can foster an ethic or respect for diversity. They have found a rapprochement between their gender and religious identity by knowing, either through scholarship, intuition, or ritual performance that the sharia is not divinely decreed but is a historical development mediated through generations after the Prophet.

Salafism has attracted much more scholarly attention after 9/11 within the broader topic of radicalization or fundamentalism. This thesis has explored the relationship between Salafism and normative gender roles in Yogyakarta in spite of the fact that there are many strands of Salafist practice and thought. Roel Meijer, professor of Middle Eastern history, avers the term comes from the Arabic word "forefathers." The question then becomes which forefathers or predecessors are to be followed, and the answer, according to Dr. Van Bruinessen, is the first three generations of Muslims. Salafism rejects the four traditional schools of Islamic law and espouses a return to the Quran and hadith as the only way of purity. This return allows individual interpretation, called ijtihad, in understanding the scriptures of the Quran and the life of Prophet Muhammad. There are many figures that shaped Salafist doctrine, but this movement reemerged as Wahhabism in Saudi Arabia in the eighteenth-century as a reform movement. ${ }^{12}$ It seems Salafism's appeal lies in the clarity it offers practitioners: its assertion of absolute oneness of God and a return to the Quran, but clarity comes at a cost. The go-betweens or intermediaries between God and humankind was sacrificed on the alter of purity. Condemned was the "veneration of the tombs of saints, holy trees, astrology, and soothsayers," many elements the

\footnotetext{
${ }^{12}$ Roel Meijer, Global Salafism: Islam's New Religious Movement (New York: Columbia University Press, 2009), 4.
} 
waria are fond of. ${ }^{13}$ Founder, Muhammad ibn Abd al-Wahhab (1703-1992) thought of the above practices as idolatrous, thus right intention and practice formed the foundation for proper Salafist comportment. Pure intention and faithful practice must align for there to be sinless acts in this view, and perhaps this marriage of authentic intention and practice could be an opening for understanding waria subjectivity.

According to Meijer, Wahhabism was a response to Western cultural influences in that its aim was to purify Islamic doctrine, not reject all models of modernity from the West such as learning English or French. He goes on to point out that the notion of insider/outsider is prominent in Salfi thinking since the community of believers strengthen their faith by distancing themselves from those outside it, and this is part of why Shiism is condemned. Interestingly, the waria and Salifists share a concern for authenticity. One revolves around the authenticity of femininity, while the other orbits around the authenticity of the hadith and Quran.

Salafism has a reputation for repressing women and exerting strict social controls, and it functions by overtly appealing to purity rather than politics. Rather than assert control over political territories, it has gained a global following by asserting a universal moral code that can translate into new identities. This moral code has three major dimensions: individual purity to build a moral social order, superior religious knowledge to trump jurisprudence and custom, an identity for individuals with clear boundaries. In Indonesia, the second dimension is most at work where local cultures are being modified. If Salafism's push for the individual to find the "real" Islam, we see a similar push in the waria community to practice their "real" selves, which encompasses religious masculinity and social femininity. External accoutrements play a role in both the Salafi and waria identity: clothing and facial presentation. The Salafi practitioner may wear a long white robe and don a beard to distinguish themselves from those that are not Salafi or Muslim. The waria attire may be a short or long skirt with wig and makeup to mark themselves as belonging to the feminine, and distinguishing from the masculine. The performativity of

${ }^{13}$ Ibid. 
identity, that is the communication of one's place in a community, often revolves around outward appearances to reflect inner beliefs.

Noorhaidi argues that the Salafi movement in Indonesia is related to Saudi Arabia's rising influence in global politics. Saudi Arabia promoted the spread of Wahhabism throughout the Muslim world as part of its foreign policy, particularly after the 1979 Iranian Revolution that brought Ayatollah Khomeini to power. The Saudi elites feared such a revolution could happen within its own borders, so they exported Wahhabism as a strategy to combat revolutionary ideas. Of note is the widespread Salafi assumption that political allegiance to any leader is suspect since all allegiance is due to the Qurran and Sunna. ${ }^{14}$

Since governance belongs only to God, Salafis distinguish between two categories of unbelievers: infidels at the level of belief and infidels at the level of practice. "While the first is no longer considered a faithful Muslim, the second is still regarded as Muslim, albeit a Muslim who commits sinful acts." ${ }^{15}$ This thinking privileges thoughts and the words used to communicate thoughts (creeds) over actions. If authenticity is derived primarily through the internal, namely, pure thought and intention, then the waria are aligned with such a philosophy. As Dr. Reza Aslan lectures, "A Muslim is whoever says they are a Muslim" because there is no authority to determine what this evaluation is comprised of, and I would add a woman is whoever says they are a woman and a man is whoever says they are a man because there is no central power to adjudicate these designations.

Deputy Minister or Religious Affairs, Dr. Pir, holds a position to legally designate whom the State deems as a legitmizte religious subject position. He lectures at a local university, is a leader on the NU national board, and serves in the Department of Religious Affairs in the national capital of Jakarta. As we sit in his living room in a posh house in the middle of Jogja, he tells me there there is a slow growing awareness that gender should not be based solely on physicality, but also on psyche. "People are not aware of the reality of transgender and LGB people. They

\footnotetext{
${ }^{14}$ Ibid., 171.

${ }^{15}$ Ibid., 174.
} 
think that if they let them be what they are, they will be dangerous for their families and religion." Pir sees the lack of acceptance of gender and sexual diversity as negative as the lack of acceptance of religious diversity.

He thinks the waria should be proactive in taking their space within a mosque if they want to enter and worship. He says Islam accepts four kinds of people: men, small children, women, and khuntha. "We also had a tradition in East Java of the warong which was a fighter who had a young male sexually serve him because the warong did not marry or have children." He tempers this libertine picture of the past with the reality of the present: "And now we have the Islamic State and people, about one-hundred people, in Solo took an oath to be part of this movement." Solo is a neighboring city to Jogja and both are considered special since they are governed by sultans who act as permenant governors. The Minister thinks young people have too little knowledge of the world knowing only the glory of Islam in the past which is now perceived as "suppressed and dominated by the West. They want to have something different and think Indonesia is too soft against Israel," he hesitates and apologetically voices, "and America."

Dr. Pir says Islam is on the move in Indonesia and it can go in either a liberal or conservative direction. "The number of ISIS followers can grow if there is no awareness an input from the mainstream to convince citizens that this kind of Islam is not the Islam of the Prophet Muhammad or at least what our Indonesian forefathers wanted Islam to be." In typical NU ideology, Dr. Pir gives equal weight to Islamic tradition (the Prophet) and local custom (Indonesian forefathers). He also brings up the nations trans state of being caught on two sides. "From the Middle East we are considered an unoriginal and heretical Islam, but from a Western perspective, any Islam is radical, so we are in a bad situation. But we can show that our Islam is better than the Middle East and we are not as bad as people of the West think." Dr. Pir stresses that change takes time. He says, "The Bahai religion that came to Indonesia a century ago, is officially recognized as of this morning." I learn the top Minister of Religious Affairs made the announcement through Twitter, and it means followers of the faith will now be able to marry, bury 
their dead in public spaces, and not lie on their national identification cards about their religious status. 


\section{CHAPTER SIX: RELIGIOUS LANDSCAPES}

The waria find themselves surrounded by a discourse of religious authenticity mostly found in the "Salafi" movement, a term that refers to the idea that the most authentic Islam is the earliest Islam, that is, the earliest generations of practitioners at the time of the Prophet and immediately following are thought to be the most pure. ${ }^{1}$ Salafis ignore the historical processes of interpretation in favor of what is thought to be an unmediated understanding of the Quran. Ironically, the Salafis call for ijtihad, as do progressive Muslims working for LGBTQ rights, in order to understand the Quran in its fullness. Literalism is often associated with the Salafi worldview since it dismisses centuries of hermeneutics by the ulama or classical Muslim scholars. This pushing aside of the social and historical context of a tradition coincides with a pushing aside of contemporary socio-historical processes, namely the LGBTQ community.

To understand how Salafism arose in Indonesia it is necessary to briefly look at how Wahhabism, another name for Salafism, emerged in the Middle East. The Wahhabi movement came out of the work of Muhammad ibn Abdul Wahhab, a reformist from the west of Saudi Arabia. He was against devotional practices such as visiting graveyards, a yearly activity the waria participate in, and advocated to returning to the original teachings of the Prophet. Jahroni notes that the Saudi Arabian government, with its official religion of Sunni Salafism, has provided billions of dollars each year for Indonesian students to study within its borders. ${ }^{2}$ Gradually, in response to modernity, Salafism shifted from the realm of purity to the realm of the political. Purification of beliefs was attached to political militancy in the form of jihad and what became known as Islamist groups.

In Indonesia, the roots of Salafism can be traced back to the religious purification movements in West Sumatra in the 1800 s. In the beginning of the $20^{\text {th }}$ century, Muhammadiyah was established and has roots in Salafi theology in that it shared the Salafi ideas of Ibn Taimiyyah, a reformer of the $12^{\text {th }}$ century. Muhammadiyah claims to be the only group not

\footnotetext{
1 Sukma, Rizal, Joewono, Clara. Islamic Thought and Movements in Contemporary Indonesia (Jakarta: Centre for Strategic and International Studies, 2007), 105.

${ }^{2}$ Ibid., 109.
} 
attached to a certain madhhab (school of thought), unlike Nahdhatul Ulama that admits four main madhhab in fiqh (Islamic jurisprudence): Hanafi, Maliki, Syafii, and Hanbali. Muhammadiyah combines elements of Salafism and modernism in the sphere of education and economy and is praised for developing an inclusive and tolerant discourse of Islam. ${ }^{3}$

Front Pembela Islam (FPI), or the Islamic Defenders Front, is a significant Salafi group in post-reform Indonesia that sees itself as just that, defending Muslims. They physically destroy bars, discotheques, casinos, brothers, and cafes since they are seen as embodiments of sin. But FPI does not act just out of a perceived religious obligation; they have political goals as well. They would like to alter Indonesia's state ideology, law, and government institutions. The FPI sees Islam as a set of regulations that can be used for all times in the sphere of religious practice and state implementation. The Quran and hadith is the ultimate authority and is to be taken literally with the final goal being the realization of the sharia. FPl's goal is to have a prosperous and peaceful state, but their strategy to get there is troublesome.

To fight "immoral acts" FPI suggests regional regulation and drafted the "Anti-Immoral Acts Law, Anti-Alcohol Law, Tithe Law, Hajj law, and Islamic Criminal Law." ${ }^{4}$ The Indonesian legal system is an adoption of the Dutch colonial system and is seen by many as no longer suitable or ineffectual to meet modern needs. Since the downfall of Suharto in 1998, the FPI sees the time as ripe to influence the national legal system. The democratic premise that authority is in the hands of the people or is "from, by and for the people" is philosophically opposed to the notion that authority is not from the people but only from Allah.

\section{Pre-Islamic Influence}

Dr. Tiga is professor of Javanese at Gadjah Mada University and is the cousin of the Yogyakarta Sultan. My purpose in speaking with Tiga is to learn about the historical role of the waria, particularly in the sultan's court. He immediately brings up the model of Arjuna in the imagination of Indonesia. Indeed Arjuna is a cultural icon; just the night before I sat with Hitam in

\footnotetext{
${ }^{3}$ Ibid., 113 .

${ }^{4}$ Ibid.,116.
} 
her room watching part of the Indian epic the Mahabharata on her television. Tiga says, "The waria were very important in the purification of the kingdom. In Java, the kingdom is a representation of the female mother, and the female can be purified by the male element because males do not menstruate or masturbate. The waria had this function in rituals such as when the king engaged in the royal ancestor worship. The waria create a pure situation because his power is like female in the tantric religion." Tiga references the $19^{\text {th }}$ century Javanese epic called Serat Centhini to ground these claims textually.

The Serat Centhini tells the story of how a prince goes on a journey over the island of Java in the 1600 s to find his siblings. The story is filled with characters that portray long-standing customs. One part of the narrative explains how some students come across a woman bathing whose husband has left her to be "a jathil (feminine partner in a homosexual relationship)." The pupils are on a trek when they come upon a village where they are told that all the boys have left to be sexual partners with male ascetics. These ascetics possess spiritual and physical powers because they do not have sex with women. The story explains that jathil eventually lose their manly characteristics and become increasingly feminine in manner and countenance. The ascetics the jathil copulate with are said to not posess real power while other Hindu ascetics who abstain from sex with men and women and most powerful because they save their sperm, that is, their energy. Village chiefs tell the students that the power the copulating ascetics do gain "gives rise to arrogance and conceit." ${ }^{6}$ This is reminiscent of the story of Lot where the Quranic infraction is hubris and not same-sex desire. ${ }^{7}$ Finally, the text describes the jathil as dancers for money or circumcision ritual specialists. This literary work is a record of a type of male-to-female subjectivity that was part of Javanese society even if it was on the margins, as we might

\footnotetext{
${ }^{5}$ Santoso, Suwito, The Centhini Story: The Javanese Journey of Life: Based on the Original Serat Centhini (Tarrytown, N.Y.: Marshall Cavendish Corp., 2006), 159.

${ }^{6}$ Ibid., 162.

${ }^{7}$ Kugle, Homosexuality in Islam.
} 
speculate it was, since initially we are told the students were jolted upon hearing about the jathil male-to-female subjects.

The students' shock quickly turned to even more than curiosity since some decide to dress up as female dancers teaching the jathil how to apply makeup in exchange for sexual favors. One pupil, Cabaloang, reports that it is "perhaps better than sexual play with women" and decides to take on the jathil role. ${ }^{8}$ The students spend the next few days having sex with the ascetics in the role of jathil, but soon leave as fully intact men with no sense of loss. In fact, the protagonists go on to have explicit love affairs with many women with Cabolang gaining magical powers to "change the size of his manhood to fit his partner for the best result and satisfaction." In another section of the story, the author recounts how a jathil, with his ascetic counterpart, demand to be paid by the crowds in the marketplace for nothing more than being present with them. ${ }^{10}$ This is not unlike the current warias' practice of assertively requesting money on the street. The ascetics refer to the jathils as their wives and ask them to cook food, another gendered behavior the waria are known to excel in. In yet another a Centhini story, a powerful regent, after having intense sexual escapades with one of the female students named Hitamwitri, asks Cabolang whose sexual enjoyment is greater: a man's or woman's? Cabolang confirms that the woman role is the most stimulating whereupon the regent immediately requests to experience this passive position. Interestingly, Cabolang obliges because he "wanted to experience what it was like to wield power over the most influential man in the territory." ${ }^{11}$ The notion of power was a significant motivator for Cabolang to be the penetrator; on the other hand, the text suggests the notion of pleasure is the primary motivator for boys to become jathil. The Centhini ends the chapter of Cabolang's adventure by having the student realize that he had humiliated many of his fellow countrymen, sexually and psychologically, and that he must repent and turn back to God

\footnotetext{
${ }^{8}$ Santoso, The Centhini Story, 167.

${ }^{9}$ Ibid., 177.

${ }^{10}$ Ibid., 164.

${ }^{11}$ Ibid., 178.
} 
the Creator. Benedict Anderson, a scholar of Indonesia and Satu's university teacher, has determined that the Centhini shows male homosexuality was unproblematic as an everyday part of Javanese society since the epic "detailed descriptions of sodomy, fellatio, mutual masturbation, multiple-partner intercourse, and transvestitism." ${ }^{12}$

Tiga recounts how such sexual practices stopped in the $20^{\text {th }}$ century because there was a cultural shift in Jogja where people began to consider the waria as morally wrong. He says the Wahhabi movement and the birth of Muhammadiya "caused us to lose our culture. The waria were pushed out of the sultan's court and society." The Sultan is still a highly respected figure both temporally and spiritually, and I ask why the Sultan did not stave off the influences that delegitimized traditional Javanese practices. "Formerly, the Sultan was able to do this, but after Indonesia gained her independence the Sultan increasingly only functioned in the cultural area." Tiga tells me the political costs were too great for the Sultans, though the ninth Sultan was stronger since he participated in the independence process, but the current one has only a few cultural functions. Tiga is referring to his uncle, Sultan Hamengkubuwono IX, who was known as a shrewd politician and picked the winning side when he lent his support and money to the Indonesian resistence to the Dutch in 1945 as well as the ouster of President Suharto in 1998. "However, when the FPI came to Jogja a few years ago, he [the current Sultan Hamengkubuwono X] allowed them to have an office, but they have no power-on this he is very strong, not in Jogja. In Solo, I think some are supporting the ISIS."

I inquire into the motivation driving ever-increasing conservatism in Java. "People have promises from their leaders_-if you do this ritual you will gain Paradise. They want to have a reward, but this is very different than former Java where we did not rely on rewards. If modern Muslims are concerned with Paradise, in the past it was about oneness, how we become one with God and we lived a happy, traditional life." Tiga is solemn and tells me the people have dogma and have lost their knowledge, even their Javanese language. "We are in a global, capitalistic situation but Java was a cultural, ecological system. It is like food; there is foreign and

${ }^{12}$ Benedict Anderson, Language and Power: Exploring Political Cultures in Indonesia (Ithaca, N.Y: Cornell University Press, 1990), 278. 
traditional food. The traditional food is more complicated and makes you healthy. I tell my students they have to know the ingredients of Javanese culture." Tiga's reference to the Javanese aspiring to oneness is telling because it has a direct relationship to how gender was conceived before colonization and conservative strains of Islam became the dominant discourse which we will look at next.

Evelyn Blackwood uses the term "gender transgression" to speak about pre-colonial ritual transvestites and modern subjectivities such as waria and tombois. She points out that historical documents do not describe the desires of ritual practitioners, only their behavior. A modern day waria subjectivity is laden with meaning since we do know their erotic desires and their behavior of mostly consistent feminine clothing. Blackwood notes that "religious discourses in which gender categoris of 'man' and 'woman' are tightly bound; gender ambiguity is unacceptable."13 This is the currect case in both the US and Java. If gender expression was more fluid and ambigious under a cosmology that legitimized such practices as powerful in Java, then that same fluidity was delegitimized as unnatural under the influence of Islamic and colonial discourses. As Butler and Foucault propose, gender subject positions are expressed in relation to linguistic and cultural frameworks. This can be seen in the archipelago as gender practices moved from imitating indigenous notions of the cosmos, i.e., Tiga's oneness, to naturalized notions of gender found in Islam and Christianity. But, a Hindu-Buddhist mythology of gender fluidity as can still be seen in the archipelago, specifically within shadow puppet theatre (wayang). Wayang characters are important models that legitimize gender transgressive practices to this day. It is important to point out that although figures like Srikandi, who was a wife of Arjuna, who transformed into a male and sired a son, kept a heterosexual orientation, that is, went from being in love as a women with male Arjuna to being in love with women as a male Srikandi. Blackwood writes, "this transformation is consistent with a sex/gender binary in which desire is always heterosexual, that is, between a man and a woman; one is only able to desire and have sex with the other sex, thus

\footnotetext{
${ }^{13}$ Evelyn Blackwood, "Gender Transgression in Colonial and Postcolonial Indonesia," The Journal of Asian Studies (2005), 852.
} 
necessitating a gender switch." ${ }^{14}$ This same type of logic can be found with my informants; they replicate the sexual binary by identifying their erotic relationships at heterosexual, yet resist (and replicate) the gender binary by transforming their male embodiment into a waria/woman embodiment. This transformation is a form of resistance; the playback of stereotypical femininity is a form or replication.

Blackwood hypthothesizes that island Southeast Asian mythologies saw the universe as gendered and in need of bringing the masculine and feminine together, or sacred deities were seen as androgynous. This led to ritualized practices that allowed ritual specialists to transgress gender norms and reunite the masculine and feminine in a religious context. Gender differences in humans, according to Blackwood, was located in the gods and thus the world was shaped by the reigning cosmology. When Tiga speaks about the earth as feminine and the waria as "males" who were pure because of their lack of erotic desire for women, he is grounding gender in a mythology that values the uniting of the masculine and feminine to recreate a sacred order that was present at the beginning of time. Later, as Buddhist and Hindu pratices began to gain currency in the archipelago, new paradigms emerged to justify gender norms.

Satu tells me to look no further than the wayang characters to find gender diversity. The Javanese word wayang literally translates as "shadow;" however, it more broadly means leather shadow puppets or shadow puppet theatre accompanied by percussive instruments called gamelan. In 2003, the United Nations Educational, Scientific, and Cultural Organization (UNESCO) designated wayang with a protective status saying the one thousand year old documented tradition should be preserved. Wayang allows a master puppeteer to narrate a story with most tales performed all night and come either from the Indonesian versions of the Mahabharata, Ramayana, or the Persian epic Serat Menak which comprise stories of the Prophet Muhammad's uncle. The puppet characters' shadows are conjured by a light source cast onto a thin, white screen which the audience views.

${ }^{14}$ Ibid. 
Like many Indonesians, Satu grew up with wayang theatre. It is used to impart local and religious stories to children and adults, even incorporating Christian biblical stories starting in the 1960s. Without delay, he describes the transgender Indian character of Shikhandi, and Arjuna's temporary cross-dressing in the forest, and the Javanese transgender character known at Kenyawandu who is the King's flirtatious and magical caretaker. He says the word "wandu" is the old Javanese word for "waria." History is not lost on this professor-turned-activist; he cites stories within the Javanese poetry of the Serat Centhini that speaks of same-sex desire. He also tells of the traditional veneration of the androgynous Hindu God known as Ardhanarishvara at the height of the Majapahit empire, ${ }^{15}$ and the East Javanese theatre form known as ludruk where male actors play women, a artistic genre that appealed to Catholic waria, Biru.

Around 12 years of age Biru, would play wayang orang, a classical Javanese dancetheatre genre that often depicts scenes from religious Hindu literature such as the Mahabharata. This type of play opened a space for her to apply makeup. After being bullied in school, she ran away at 17 to the second largest city in Java: Surabaya. "I entered the world of art and I was so happy. I played wayang, ludruk, wore makeup, and lived with men there. I was so comfortable." Biru continued dancing for a decade joining various dance troupes including a Ramayana ballet. Biru, like half of my interviewees, spoke about how her family worried about her going out at night because they knew the warias' main occupation was sex work and this was the most disgraceful aspect of their identity in the eyes of the larger community.

As Islamic beliefs and the Dutch East Indies company (with their Christian beliefs) came to gain power in the archipelago, Blackwood sees the mythologies that gave magical powers to those that bridged masculine and feminine recede. "The mythologies of sacred gender were subsumed or replaced by a mythology of 'innate' gender . .."16 Since Islam was largely mutlivocal in its doctrines until Wahhabism came on the seen, the male-to-female subject position found a legitimate place as Tiga said, until the early $20^{\text {th }}$ century. Sufi Islam, which largely incorporated

\footnotetext{
${ }^{15}$ Nancy Dowling, "The Javanization of Indian Art," Indonesia, no. 54 (1992), 117-138.

${ }^{16}$ Evelyn Blackwood, "Gender Transgression in Colonial and Postcolonial Indonesia," The Journal of Asian Studies (2005).
} 
local beliefs and practices, allowed the spirit world and traditional cosmologies to live side by side until a wave of "purification" made it's way into Indonesian culture most apparent with the founding of Muhhamadiya.

Because Islam has a tradition of a chain of narration leading back to the Prophet, a topic I take up in the next section, knowledge was seen as passing down from the Prophet to another man, and from there through a chain of men. This meant that the relevance of the religious feminine was backgrounded and the scriptures of the men created firm gender boundaries based on the Quran where man was created with woman as his spouse. Gender became fixed in Islamic discourses as the old archipelagic cosmologies of dual gender deities disappeared. "The new binary naturalized a gender hierarchy that invested men with greater portions of strength and reason, while women were considered more vulnerable to human weakness and passion (nafsu)." ${ }^{17}$ More strikingly, Blackwood argues that women were no longer seen as generating life, but simply reproducing life as their duty demanded.

The Dutch, who landed in the late 1500s, brought a patriarchal culture where women were subservient to men. They also brought a legal code that that helped form the legal system of what is today Indonesia. Blackwood writes that, "of all the European countries, the Netherlands was particularly harsh in its treatment of same-sex sexuality and "cross-dressing."'18 Apparently, men were prosecuted and sentenced to death for homosexuality under the courts of the Netherlands. Under colonial and modern Islamist discourse, those that did not comply with gender norms in the archipelago were no longer seen as combining genders in legitimate ways because "these new gender transgressors were considered to be false approximations of a gender that was not theirs." ${ }^{19}$ With Islamic, colonial, and Wahhabi discourses overlaying traditional Javanese discourses of cosmology, once sanctioned gender transgressive practices were transmuted into practices against nature since a gender binary was God-given.

\footnotetext{
${ }^{17}$ Ibid., 862.

${ }^{18}$ Ibid., 864.

19 lbid., 865.
} 


\section{Post-Colonial History}

Post colonial Indonesian history can be seen in three sections: the Old Order, the New Order, and the Reform period. President Sukarno was in power from independence starting 1945, and he founded Indoneisa on the Pancasila or five principles that guide the country to this day. In 1967, the second President, Suharto's New Order proceeded to uphold Pancasila vis-à-vis conservative groups that would rather uphold sharia. In 1998, with Suharto's autocratic regime falling, political parties and outspoken ideologues called for a more observant Islam in the public sphere. Just days after I arrived in Java, people began discussing an attack on several Christian churches in Jogja most suspecting the FPI, a group that would not have been allowed under Suharto's New Order, of ill will. As one informant told me, he would open a gay bar in Yogyakarta if he could afford the large bribe he would have to pay the FPI monthly to keep them from attacking such an establishment.

The idea of Islam as a political tool did not take root until Suharto's later years of autocratic rule when he tried to broaden his sphere of power beyond the military. ${ }^{20} \mathrm{He}$ pilgrimaged to Mecca in 1990 creating a veneer of Islamic ethos as was his reversal of the ban on the head covering for female students in state schools. Indonesia has always had a pluralist view of Islam; however, two major schools of thought that can be classified as "modernist Islam" and "traditionalist Islam" have held sway. These schools were represented by two Islamic organizations: (modernist) Muhammadiya created in 1912 and (traditionalist) Nahdlatul Ulama created in $1926 .{ }^{21}$ With the fall of the New Order, the ban on Islamic political ideology also fell and "the birth of new Islamic political parties" has complicated the face of Indonesian Islam. ${ }^{22}$ Nahdlatul Ulama (NU) and Mauhammadiyah were both birthed on the island of Java, with Mauhammadiyah born near the location of my study in Jogja.

\footnotetext{
${ }^{20}$ Sukma, Rizal, Islamic Thought and Movements in Contemporary Indonesia (Jakarta: Centre for Strategic and International Studies, 2007), 8.

${ }^{21}$ Ibid., 9.

22 Ibid., 10.
} 


\section{Prohibited and Permitted Humans}

Moshere, one of my interviewees who leads a Salafi mosque a few blocks from where I am living, holds convictions that are increasingly common in Yogyakarta. He is the most hesitant of any interlocutor to speak to me and has lots of questions about why I am writing about the waria and what I will do with the information. He grudgingly agrees to an interview after feeling minimally satisfied with my responses. He recounts the Salafi party line: the waria are homosexuals which is prohibited by the Quran, and men who act effeminately are prohibited by the hadith. Moshere explains to me the two-fold distinction of khuntha, or those born with both genitals, and mukhannath, or effeminate men. He tells me the khuntha are "acceptable," but should remove the genitals that do not align with their behavioral tendencies. The mukhannath, on the other hand, "practice homosexual acts and are considered sinners and are suffering form a mental disorder that needs to be treated and cured, like people who are kleptomaniacs need to be treated. We will not disregard it. The same goes for exhibitionism." Moshere lumped gender identity, stealing, psychological instability, and indecent exposure into one category to mean the warias' behavior create an unhealthy and sinful identity that needs medical and religious intervention. "When talking about the pesantren waria, if their goal is to treat them to become men then that is good. If it is to legalize and accept their existence, then I don't support it. We only have two genders, not a third based on the Koran and Sunnah."

Saiful echoes Moshere's stance on the permissibility of intersex individuals which he sees (incorrectly) the waria embodying. Saiful is in his late twenties and is getting his master's degree in Islamic Education. He lived in a pesantren for 6 years and considers himself part of Nahdlatul Ulama. He has been volunteering at the ponpes for over a year and tells me the waria have both reproductive organs so they can choose what they want to be. I realize as Saiful is speaking that he has no idea what the waria's anatomy is because it would be rude for him to ask anything that may be embarrassing, especially since he only sees the waria during religious lessons. I am around the waria in many different contexts and take full advantage of my position as a researcher to ask personal questions. I inform Saiful that the waria have male genitalia only. 
He rejects this notion and tells me that if I observed more deeply I would see that both are present. He does admit there is a type of "unreal waria who are men that want to be women," but this is not the case at the pesantren. Since the waria need all the support they can get, I am not going to say anything that might further alter Saiful's thinking. Because of this dual physiology, Saiful says the waria can decided which gender they want to live out so they can be heterosexual. In this way of thinking keeping the "naturalized" sexual order is tantamount to keeping moral order through an Islamic lens.

Belimbing, a religious leader in Jogja, employs a discourse of nature as he tells me the waria will not be able to enter an economically or religiously viable world until they change. I relate to Belimbing the humiliating experiences the waria face when they enter the mosque to worship on the men's side. He insists they must pray as men and "we cannot blame the men who step away from them since they are shocked and haven't been socialized about this." He also declares the waria must be buried as men regardless if they request not be or have had sexreassignment surgery. Belimbing considers the waria men and homosexual "which is against nature. Although Belimbing identifies the waria as men because they have a penis, he cannot deny the waria do more than just act effeminately. "The waria are wrong because their gender is between a man and woman - they create a new gender that is not admitted into Islam. We have clear rules for men and women about how to pray." He founds gender dimorphism on the purity of prayer forms, and not foundational texts of the creation of the world as is common with Western Christians that point to Adam and Eve as the first humans. Ultimately, in Belimbing's perspective, gender is still decided based on biology whether that is through tissue (penis/testes/vagina) or liquid (semen/blood).

I ask if God has a gender. "God does not, he is neither a man nor woman." I bring up the idea of the bissu (androgynous shamans) in South Sulawesi and wonder if the waria could be closer to God for also being neither man nor woman. "God's laws cannot be equalized with human laws because human beings are God's creation. The waria have a gender, but they deny it." Not surprisingly, Belimbing sees the best strategy to accomplish the goal of "bringing the waria 
back to normal with marriage, family, children and work" is through the creation of a pesantran waria where they can learn the correct teachings of Islam. Belimbing sees an acceptable nonnormative body in the intersex khuntha, but not in the male-bodied waria. This is similar to the jurisprudential discourses in Iran that distinguishes between acceptable intersex trans embodiments versus deviant homosexuals categorized as criminals. ${ }^{23}$

On the other hand, the kyai (religious leader) holds the most respected position in the pesantren, and since a culture of pesantrens shape Indonesian society, a kyai holds persuasive power over what is evaluated as acceptable and deviant. The fact that the pesantren waria has ushered in the favor of kyais has allowed them to negotiate their presence in a Sunni Muslim milieu that may not hold Arab practices of stoning or honor killings, but do sanction those that step outside the bounds of normativity. I hope to problematize the illusion of a monolithic Islam and give rise to disparate voices that see Islam as calling forth deep values of compassion.

Traditionally the kyai is ever-present at the pesantren when students engage in their textual studies and offers oral knowledge and contemplative meaning behind the text. Because the pesantren waria is not a boarding school, the official kyia resides a couple miles away only attending the pesantren on special occasions such as when I met him to celebrate Nuzulul Quran; the day that commemorates when Muhammad first received divine revelation through the angel Gabriel. The ponpes arranged Quranic recitation and invited leaders, and those volunteers that give of their time to teach the waria Arabic, to come to the celebration.

\section{Religious Legitimization}

The pesantren waria's kyai is a charismatic and confident personality, Kyai Anggur. He greets me outside his front door. He founded an NU pesantren in Jogjakarta in the late nineties, first for boys and then a second for girls. He was a student at a pesantren and says establishing his own gives a great sense of accomplishment in his sixth decade. He has four children, and one is finishing her doctorate at John Hopkins University in Maryland. Anggur is the official leader of the pesantren waria thus representing the transgender community to the wider Islamic

\footnotetext{
${ }^{23}$ Afsaneh Najmabadi, Professing Selves: Transsexuality and Same-Sex Desire in Contemporary Iran (London: Duke University Press, 2014), 4.
} 
community, not the easiest task. I know this is a different kind of pesantren because I see on the wall next to me symbols from the world's major faiths such as a Buddhist dharmachakra, a Confucian bell, a Christian crucifix, and one symbol I do not recognize hanging between the Muslim crescent and the Hindu omkara; it is an outline of two palms pressed together as if in supplication. I learn it is the symbol of Javanism or kebatinan, those beliefs and practices in Java known for their hybridity of animism, Hinduism, Buddhism, and Sufism.

I what Buask makes this pesantren's curriculum different. "I am the curriculum," Mukaimin quipped. He explains that three processes are supposed to occur in a pesantren education: a transfer of knowledge, values, and spirituality. "In modern pesantrens, maybe one of those occurs - the transfer of knowledge, and maybe a values transfer, but not intensely." As can happen with magnetic personalities, I thought this guy either has an enormous ego, or he is speaking from a place few do. "For example, every day I pray for the students; after prayers I read Al-Fatihah (beginning verses of the Quran); every evening I ask the students to pray for an hour alongside me. Modern pesantrens don't practice these habits. Even the students that have graduated I still pray for, so there are no alumni." He notifies me that all students virtually stay for free only pitching in for electricity and basic bills; I cannot get a clear answer on how he finances himself, his family, and his two educational institutions.

Anggur says he agreed to lead the pesantren waria because we live in a pluralistic country where "everyone has the right to practice and actualize his or her religion. The waria have no knowledge about religion or psychology; we should accommodate them to find their religious identity regardless of their sexuality and gender." I know this is a sensitive subject, yet Anggur appears completely at ease. "Personally, I do not focus on fiqh (law); I only focus on the humanitarian side because with fiqh comes controversies on technicalities such as how to pray. I think a new fiqh should be created because it adapts with the era, with gendered perspectives, with human rights, with a waria perspective." I feel a mixture of relief and inspiration hearing these words because Anggur is speaking from within a long Islamic tradition that challenged and debated how legal rulings were decided and applied in relation to the actions and sayings of the 
Prophet known as the Sunnah. He tells me there must be a dialogue to bring about a new law. "One side thinks that waria should be forbidden, another thinks they are okay to be themselveshow do we find common ground" he rhetorically needles.

The foundation the kyai comes back to again and again is privileging the human being as the most valuable. Leaving himself open to speciesism, he avers, "We have to resort to humanism—waria are people and human and created by God, the best creature of all." Anggur intoned the name Al-Ghazali as one of his teachers. Al-Ghazali is the most well-known medieval Persian mystic, ranking right behind the Prophet and Rumi, and considered a giant in Sufism. "From a fiqh point of view, there is no way a prostitute would get into heaven, but from a Sufi point of view, when a prostitute feeds a dog out of the kindness of her heart, she can enter paradise." But I counter that Sufism is not informing those hardliners that are opposing the waria. "Exactly, there should be a radical change of paradigm. Their approach to law is very black and white, haram or halal. There is no room for tolerance when concentrated on fiqh." He describes how imams get fixated on how a woman should behave or how a man should behave opposed to how they should have the right to become a faithful follower of God.

When I ask the kyai to define what waria means he tells me they are "the ones who have multiple sexual orientations due to differences in their chromosomes. I don't really understand the details because it's medical. I see them as humans and I have respect because humans are the most perfect creation of God." His initial response is to identify the waria in terms of sexual attraction and then link that attraction to a genetic foundation that is beyond his scope, admittedly. His second impulse is to link the waria to God's creation that deserves dignity. The latter part of Anggur's response is particular to a person who lives within a plane of piety, namely, the divine encompasses all creation. This kyia's interpretation of waria gives us a glimpse of how enmeshed gender and sexuality are in the Indonesian imaginare. In this study, I am using four categories of analysis and suggesting these four elements comprise an assemblage of tangibles and intangibles we call gender: identity, expression, biology, and attraction. I posed a question that I interpreted was about gender identity, i.e., how do you define the word waria? I received a 
response about sexual orientation suggesting the separation of gender identity and sexual orientation is an imposition I am executing, and not distinct emic categories for this interlocutor.

"I have a theological principle, and that is we shouldn't think about God, but we should think about God's creation because we have limited intelligence and capacity to endure God." This principled silence is ironic since this kyai has God on his lips constantly, though an expansive view of such a deity. He is well aware the waria mostly pray as men and thinks it is fine if they choose to pray as any gender. "That's why I don't see the waria in a figh perspective. How about when they go on the hajj (pilgrimage to Mecca)? What outfit will they wear? I would like to think they can wear whatever outfit they are comfortable in." Anggur has not made friends with such an embracing ethic. He is a controversial and respected leader in Jogja and he says he is viewed with animosity in the eyes of conservative imams while being called an enemy of Islam. And with regard to FPI, he says they are not a part of Islam, but political theatre:

FPI would bash anyone who does not conform to their ludicrous views, catering to their client's orders. All I can say is that I do not see Allah, but I do see Him. When I see a tree, I see Allah-his power through it. When we talk about knowledge, the Quran and hadith are the written creation and the universe is the reality of creation-both must support the other.

Anggur has hit the nail of the head; the waria may not have the textual training to maneuver the religious discourse communities surrounding them, but they have knowledge of an equally important book: "the reality of creation" or signs (ayat) that bespeak of God's miracles and are a type of communication to the faithful, as powerful as the Quran (another type of sign) which show God's intention and love of diversity.

\section{Quran}

As I look at the main text my Sufism class is employing this semester, I see a typical pattern: Indonesian Islam elided from the conversation. The Dutch "were stingy" Satu would tell me about the lack of education the Dutch provided to the colonized. Indonesians were ruled by a Dutch-speaking empire, not an English crown as was the case with British colonies, so Indonesians were not given the linguistic tools to enter the academic discourse that Middle Eastern, South Asian, even sub-Saharan Africa acquired. Our post-colonial legacy has left a 
dearth of Indonesian Islamic monographs and an aEmasnce of Arabocentric notions that "true" Islam can only be found in Arabia. My Indonesian friend warned me before I arrived in Java that the populace suffers from an inferiority complex. I did not have to look far to see it. When I walked into a store to buy soap, shaving cream, facial cleanser, I had to search for substances that did not have bleaching agents suggesting colorism was rampant. When I walked down the street, almost every woman was wearing a Middle Eastern or South Asian style hijab where the opposite would have been true just a few decades ago. Religiously, a syncretic portrayal of Indonesian Islam has connoted inauthenticity and impurity to citizens inside and outside of the archipelago. One strategy Indonesians have employed to overcome this perceived weakness is imitating the culture of the Middle East. If Allah revealed his word in Arabia, the closer to Arabian culture, the closer to Allah goes the logic. The fourth President of Indonesia, Abdurrahman Wahid, try to counter this logic by coining the term "local orthodoxy" to refer to keeping the universal values of Islam, but embracing different manifestations of it instead of conflating Islam with Arab culture. ${ }^{24}$

At the center of the contestations for local or Arabic orthodoxy are kyai who are more than respected teachers. Mark Woodward describes them as "charismatic religious authorities who are believed to have unique abilities to communicate with God, as channels through which God's mercy and blessing enter society." ${ }^{25}$ It is no wonder PKBI and the waria worked together to strategically gain the blessing of several kyai in the founding of the ponpes. And just as parents are honored if a kyai names their child, the the first kyai of the ponpes, Hamrolie, named the pesantren waria "Al-Fatah" or "The Opening."

The waria, for the most part, have a low socio-economic level and therefore have not been trained to draw upon theory and theologians to justify who they are what they do. They call upon their positionality in the world as persons who endure through injustice, and therefore they read their sacred texts as calling for greater justice and empowerment because this is what Allah

\footnotetext{
${ }^{24}$ Oliver Leaman, Controversies in Contemporary Islam (New York: Routledge, 2014), 30.

${ }^{25}$ Bianca Smith and Mark Woodward, Gender and Power in Indonesian Islam: Leaders, Feminists, Sufis and Pesantren Selves (New York: Routledge, 2014), 11.
} 
calls for. Consistently, the waria pointed to ustadz pontificating about holy text rather than the text itself evincing the waria deeply understand that words are dead without the interpretation words must pass through. There is a long and dense tradition of interpretation (tafsir) throughout the Islamic world. In Speaking in God's Name, El Fadl relates a story of how the fourth caliph, Ali, was accused of following the judgments of people instead of God. In response to this accusation, "Ali gathered the people and brought a large copy of the Quran. He touched the Quran and proclaimed, 'O, Quran speak to the people.'” The people questioned if Ali was mocking them and said, "It is but paper and ink." Ali made his point clear that human beings are needed to make meaning of the text. ${ }^{26}$ The waria know the wisdom of Ali and they have resisted their oppression by forming their own space, even if that choice appears at times to replicate the patriarchal society they live in: waria pray as men because they posses biological male organs. The waria are making an internal choice to pray as men, but not because they are men, but because they are pious waria that were born with male reproductive organs. There is a shift in power that is taking place in the waria that pivots away from the game of submission and rebellion to a religious authority, to one that orbits around the inner self of the waria subject position, even if that subject makes a choice to follow a patriarchal paradigm.

Kugle makes the case that gender and sexual diversity is encoded into the Quranic scriptures using Surah 49 and verse 13: "O people, We created you all from a male and female and made you into different communities and different tribes, so that you should come to know one another, acknowledging that the most noble among you is the one most aware of God."27 This verse can be interpreted to uphold Indonesia's national motto of "Unity in Diversity," because through difference in ethics and epistemology, awareness can grow which in the above verse translates to closeness to God. Kugle also cites Surah 30 verse 22 to valorize difference: "One of God's signs is the creation of the heavens and the earth and the diversity of your tongues and your colors, in which there are signs for those who know." In this exegesis, color refers to outer

\footnotetext{
${ }^{26}$ Abou El Fadl, Speaking in God's Name: Islamic Law, Authority and Women (Oxford: Oneworld, 2001), 24.

${ }^{27}$ Kugle, Homosexuality in Islam, 44.
} 
and inner realities and passions that are divinely created and although ulama from the past may not have explicitly tied such verses to sexual orientation or gendered embodiments, it is a reasonable endeavor as Kyai Anggur related.

A couple ustadz mentioned the destruction of the tribe of Lot when referring to the waria's sinful homosexuality. A Western audience may be familiar with the biblical version of this story, but the Quran tells the tale in fragments dispersed throughout the text. The position of one of the leading thinkers in the Muslim world a thousand years ago, Ibn Hazm, writes that this story is not about man to man sex, but "infidelity and rejection" of the Prophet Lot which, demonstrated through sexual assault, the tribe was punished. ${ }^{28}$ I bring this point up to reveal how a focus on the sexual aspects of the story of Lot can foreground an interpretation of homosexuality instead of the sexual violence of male rape.

Merah is the only waria that brought up the story of Lot in the Quranic story about the city of Sodom that was destroyed. She warns that this story does not apply to waria and that "it is clear the Quran ensures human rights; however, not as clearly as the Declaration of Human Rights. The values of the Quran support human rights. We have to know our human rights exist at birth while Islam's norms were born in the $7^{\text {th }}$ century." The awareness of context and the recontextualization process Merah is advocating here is akin to liberation theology movements that invigorated parts of South and Central America that advocated for economic justice, and for Palestinian Christians in the Middle East who advocate for a non-Zionist hermeneutic.

Islam does not have a perpetual monastic tradition, even among the Sufi orders that at times isolated themselves to more clearly hear God. Life is lived integrated in the social order and sexual activity within marriage was affirmed and played a positive role in jurists from all schools. But a sex positive approach to the Quran is not a dominant voice and as Michel Foucault writes, "There is not one but many silences, and they are an integral part of the strategies that underlie and permeate discourses." ${ }^{29}$ Kugle wants to undercut the strategy of silence around intersections

\footnotetext{
${ }^{28}$ Ibid.

${ }^{29}$ Michel Foucault, The History of Sexuality (New York: Vintage Books, 1990).
} 
of genders and sexualities and sees Surah $42: 49-50$ as lending itself to articulating a multiplicity of embodiments. "To God belongs the dominion of the heavens and earth. God creates whatever God wills and gives to whomever God wills females, and gives to whomever God wills the males, or pairs them as male and female. And God makes whomever God wills not reproduce, for God is One who knows all, One capable of all things." ${ }^{30}$

One perspective on this verse follows that cisgender males and females are first mentioned followed by an embodiment that is both male and female. Kugle sees this as a possibility for intersex or transgender people to stake a claim to their divine nature. Moreover, those that are not reproducing may be implying gay and lesbian people that would noth engage in reproductive sex. Musayyin's interview brought up Surah 24:31 where women are told to hide their charms but not from ". . . men as attend them who have no desire ..."31 Kugle takes this verse up in his analysis suggesting that these types of people are exempt from the rule of separating from women which can be a boon for waria who are scolded for working in beauty salons with cisfemale customers as Ungu mentioned. "Classical interpreters thought this verse applied to elderly men or impotent men whom they assumed were exempt by fiat of age or anatomy." 32

Tiga, the Sultan's cousin, mentioned that he sees Wahhabi-informed Islam as creating the conditions that shifted public opinion on the waria. In fact, Wahhabism shifted the richness of ambiguity in textual exegesis from plasticity to heresy. Since the waria are not schooled in Islamic sciences to debate finer theological points, their voices are silenced from a debate that needs them. It can be assumed from the warias' responses that they would voice an ontological argument around how they were created and "destined to be" transgender akin to the Western world's "genetically born this way" logic. And some of the religious leaders I spoke to would counter that if non-normative genders and sexualities are present from birth, such medical

\footnotetext{
${ }^{30}$ Kugle, Homosexuality in Islam, 66.

${ }^{31}$ Haleem, The Qur'an: A New Translation, 222.

${ }^{32}$ Kugle, Homosexuality in Islam, 67.
} 
pathologies need to be addressed, and if they are not present at birth, such immorality can be cured through God. Notwithstanding measured jurists such as Ibn Hazm, the classical past and the contemporary present have employed Islamic texts to make gender/sexual minorities abject. If we allow that sex was used as weapon in the story of Lot, and this was part of the shamefulness that brought about the people's demise, then the waria cannot be projected into this category: the waria use sex to survive.

Hadith

The waria were quicker to mention the concept of hadith, the sayings of the Prophet, than the Quran as they recalled how religious leaders would either legitimize or delegitimize their identity. The diversity of hadith is immense as are the ideas of its proper function in forming Islamic praxis. A system to judge the ethos of each hadith was developed in an attempt to cull out those sayings that were not considered credible. Authenticity is important for Islamic scholars and for the waria. Ulama, at least in the past, engaged in critical analysis to determine the strength of the chain of transmission of the Prophet's words, although this intellectualism has decreased with modern Wahhabi beliefs that minimize interpretative frames.

The waria want to playback femininity in their behavior, dress, and sexual comportment as authentically as they can while also ensuring they are attracting "real" men. Just as gender roles have no stable base of authenticity since they change with time and culture, neither does so-called Orthodox Islam in in neo-traditionalist flavor. "Orthodoxy has a history, and in its history the hadith occupy a place that has been constantly contested. ${ }^{33}$ Kugle raises the question of reliability within a chain of narration going as far as calling the Quran a type of hadith or report "about God's speech to Muhammad, the authenticity of which guaranteed by continuous multiple chains of trustworthy narrators (hadith mutawatir) from the Prophet's own time to the present."

Hijau felt inspired to join the ponpes to learn about Islam's multivocal voice on how one is to live in accordance with God's will. People from her village told her Islam condemns waria and

\footnotetext{
${ }^{33}$ Ibid.

${ }^{34}$ Ibid.
} 
she is seeking religious knowledge so she can respond to her accusers. Hijau is brave; she returns to her village dressed as a woman. I found half of the waria return to their villages dressed as men in an attempt to not bring shame on their family and knowing the hadith that says men who act as women are cursed. I was surprised the day I saw Emas cut off all her hair so she could present a more masculine appearance to her family when she visited her village at the end of Ramadan.

Hijau is a sex-worker, yet opened a hair salon one month ago. She would like to spend more time joining the activities at the ponpes, but doubts that is realistic since her clients keep her out until 5 in the morning. She says she would like to learn to read the Quran, and she doesn't understand why some ustadz don't accept the waria. "God created many creatures in the world like plants—-there are many kinds of plants that He created. Why can't humans be different? It's the same for the stars-they have different shapes and forms. Why do humans have to judge other humans who are God's creatures?" She sees others as misinterpreting the Quran and hadith and causing division. "Even Islam itself is separated. There is Muhammadiya, Ahmadiyah, while God gave only one teaching through his words to the Prophet Muhammad."

Slowly, different schools of Islam emerged based on foregrounding certain sections of the Quran and bodies of hadith. Scholars distinguished between the reliability of different chains of transmissions and separated what was said by the Prophet, what was said by his companions, and what was said by others. The most valuable kind of hadith report is known as mutawtir because it has a multitiude of narrators that agree upon the information being conveyed. Kugle writes, "No hadith report about homosexuality or transgender behavior is mutawatir in its wording." ${ }^{35}$ The intricacies of the sifting process of what is more or less authentic is beyond the purview of this work, but there is a feminist tradition from Islamic practitioners that interrogates the sacred texts. ${ }^{36}$

\footnotetext{
${ }^{35}$ Kugle, Homosexuality in Islam, 80.

${ }^{36}$ Fatima Mernissi, The Veil and the Male Elite a Feminist Interpretation of Women's Rights in Islam (Cambridge, Mass: Perseus Books, 1991).
} 
There are some hadith dealing with mukhannah that have survived in various forms which tend to suggest that narrators were working in their rhetorical realms and used their words for different audiences and for different purposes. Although no ustadz could tell me the source of their knowledge, the most common trope I heard when criticizing the waria was that "the Prophet cursed men that acted like women." The ustadz are referring to a saying in what is considered the most authentic compilation of hadith authored by a Persian scholar named Al-Bukhari in (810-870 C.E.). The report details how a wife of the Prophet, Salama, was with a mukhannah named Hit in a room on the night before a raid. Hit told Salama's brother, Abdullah, that if he is successful in raiding a town called Taif, that he should go after a beautiful woman in town who has four belly rolls of fat in front and eight in back, a trait in that time that was considered arousing. Upon hearing about the mukhannah's words, the Prophet exclaimed such male-to-female people should not be allowed in the presence of females. ${ }^{37}$ It is unclear what the Prophet's motivation was in wanting to banish the mukhannah from the secluded women; however, the two main speculations is that he wanted to stop Hit from luring Abdullah into following his sexual lust "for Hit used his exemption from gender segregation to reveal the beauty of a woman's body to prying eyes and possibly predatory intentions. ${ }^{38}$ It is generally considered by scholars that the Prophet's pronouncement was not a juridical decision based on gender identity, but a specific opprobrium to one person based on a transgression of norms. ${ }^{39}$ Following the nature of oral literature, details and context can be lost as memories are handed down through generations creating a rhetorical realm with propagandistic purposes, what Michel Foucault might call "a regime of truth" that strays from the original intention of the speaker.

Islam's tradition of assessing weak and strong hadith faded to non-existent under the spread of Wahhabism which regarded such practices as heretical leading to an erasure of

${ }^{37}$ Susan E. Henking, Que(e)rying Religion: A Critical Anthology (New York: Continuum, 1997), 64.

${ }^{38}$ Kugle, Homosexuality in Islam: Critical Reflection on Gay, Lesbian, and Transgender Muslims, 94.

${ }^{39}$ Susan Henking, Que(e)rying Religion: A Critical Anthology, ed. Gary Comstock, 67. 
intellectual inquiry. Kugle argues that the concept of hadith is analogous to the notion of family that holds sway over Muslims. Although individual family members can be questioned and critiqued, the family as a whole has an authority that profoundly affects individual members, not unlike the role of hadith as individual rememberings and as a unified field of thought.

One informant who sees himself as living under the guidance of hadith is Kelapa who introduces himself by saying he has four children and one wife and is a member of Wadah Islamiah Indonesia, an organization created in the late 80 s "to purify Islamic teachings and law and follow the first generation of Muslims although we don't call ourselves Salafi." The only difference I can discern between Kelapa's organization and Salafi ideology is that Kelapa is more concerned about originality since he wants to imitate the first generation of Muslims vis-à-vis the first three that Salafi ideology espouses. "We teach Islam so the community can return to the pure and original sharia and practices based on the first Islamic generation." Kelapa and I are sitting in the most luxurious mosque I have seen in Jogja. The interior houses grand white columns with resplendent gold capitals as high as the pointed archways. We sit on the floor next to a panel of carved Moorish woodwork. Kelapa finished a talk to the congregation moments before our interview.

He expresses how the Prophet's peers were taught "the pure, clean, and original message without being influenced by contemporary teachings that distort." He describes how the ulama (scholars) divide non-normative gender into three categories: men that act like women, woman that act like men, and someone born intersex. This is the first of my informants that has mentioned female-to-male subjects, a more underground sub-culture known as priawan, a neologism combining the Indonesian words man (pria) and woman (wanita). He says the first two groups are not allowed "because they are against the nature of God, while the third is not disgraced because they were born and destined by Allah to be like that. But they must obey the rules or it will cause calamity for themselves and all people."

When I ask why God would create intersex individuals, but only explicitly regulate men and women, Kelapa redirects me to consider my meta-perspective. He implicitly argues that I am 
focusing on life now rather than focusing on eternal life in heaven and this earth as a temporary trial. He is sidestepping my questions so I am direct:

"Why do waria exist?" "They are influenced by their social environment. It is a mental disorder, not their nature and God's destiny (fitrah), and it can be healed." He systematically goes over the different scenarios that can influence a child down the wrong path: parents dressing the child in the wrong clothes, socializing with the wrong gender, being disappointed by boyfriends/girlfriends, imitating idolized role models on television programs such as transvestites. He mentions the name of an Indonesian television station that plays popular shows and movies: Trans TV.

Kelapa does not support the pesantren waria. "If we give them a special community it means we accept their existence and this will have a bad impact because God's will and man's nature is to have descendants. The best way to change the waria is through mental therapy and second, is to force them into manly habits so they can adjust themselves. In Islam, we say it is easy to imitate what one sees." He is convinced that it is impossible for God to place a women's soul in a man's body. Congruent with his search for origins Kelapa tells me that God "created us in a pair, man and woman to complement each other in order to harmonize this life." In his mind, the waria are homosexual, are going against Islam by modifying their bodies, and "will cause chaos and disease and disorders." And that chaos will have reverberations because "Islamic law doesn't only regulate this life, but what happens after we die." This is why the waria must be buried as men.

He says the waria have a 50/50 chance of entering heaven. "If God forgives him, he will enter heaven, but if God doesn't forgive him, he will enter hell. But, he doesn't live in hell forever because after being tortured equal to his sins, he will be able to enter heaven." Since one way to compel forgiveness from Allah is to pray, I bring up the insults the waria suffer when they do enter mosques. "Most people don't like the appearance of waria so they get away. Most only enjoy waria when she is on television shows. In fact, most people think waria are disgusting and are afraid. As Muslims, we should not do that because our purpose in coming to a mosque is to pray and not refuse someone." Kelapa is speaking honestly. When the waria are safely boxed within 
the frame of a television set, they are distant and risible, but outside that box, they are disturbing and rattling. Ben Murtagh suggest that increased violence against sexual and gender minorities in Indonesia may be related to the increased visibility such communities have through popular media and cinema. ${ }^{40}$ This visibility leads to the type of discourse I am having with Kelapa and creates a type of identity politics that is not present for thos sexual minorities that are not visible: gay, lesbian, and bisexual subjects. Most waria do not "pass" as women on the streets of Jogja if they have had silicone injections, and the way the waria are constructed on screen reflects the distinct look of the waria.

Kelapa is trying desperately to climb his way out of his own trans condition: the unique ordering of Indonesian Islam. If bodies are more pure and authentic when they adhere to their assigned gender at birth, religion is more authentic when it adheres to the assigned norms present at the time of its birth: seventh century Arabia. In the book Sexuality in Islam, Tunisian sociologist, Abdelwahab Bouhdiba, notes that adultery "is a disorder in order: it does not strictly speaking violate the fundamental order of the world . .." ${ }^{41}$ If heterosexuality can be lived out in an acceptable way through marriage and in an unacceptable way through fornication or adultery, then waria homosexuality is beyond disorder, it is a chaos of unintelligibility. It is not a cognizable option to be a gender or have a sexual orientation outside of what anatomy seems to dictate or society deems appropriate. This is akin to the identification card every Indonesian is required to carry where they must declare their gender and martial status. The options are male versus female and married versus "not yet married." The opposite of marriage is not single, it is marriage delayed. It is incommensurable to think of a public structuring of society that allows perpetual singlehood in the Salafi worldview. This national identification card links citizenship to categories of gender and sexuality and sets the limits of what is within the orbit of order and disorder by defining the discourse of what can be. A gender outside of male or female, a status outside of married-now or will-marry-in-the-near-future is indicative of a failed citizen.

40 Ben Murtagh, Genders and Sexualities in Indonesian Cinema: Constructing Gay, Lesbi and Waria Identities on Screen (New York: Routledge, 2013), 4.

${ }^{41}$ Abdelwahab Bouhdiba, Sexuality in Islam (Boston: Routledge \& Kegan Paul, 1985), 30. 
Fiqh

If Kyai Anggur wants to demphasize Islamic jurisprudence (fiqh), then my next informant, Kurma, wants to uphold figh as central to a proper Islamic identity. Kurma agreed to meet me at 5 in the morning at his village pesantren on the northeastern Coast of Java. He's the son a prominent scholar, so he is called a "gus" as a title of respect. I arrived the previous evening to watch students set up a stage for the Quran memorization contest taking place that weekend. Kurma is part of $\mathrm{NU}$ and says that waria can choose to pray as men or women when they enter a mosque, but they cannot lead the prayer services of men, only women. He tells me that he has never had a waria student and discloses that he feels afraid of them "because they try to attract men and then attack if you don't respond." He informs me that the waria should in fact change to become men so they can follow the inheritance laws and prayer forms properly. I remembered Perak said her family gave her a woman's inheritance upon her parents' death: half of what her brothers received. Kurma says, "We have to receive our destiny and not break what God creates-man and woman. We have to accept the nature of our life." I ask if it is possible that God created a third nature outside of man and woman. "If we are talking about God's power, there is nothing impossible with God." Kurma grounds the naturalized state of man and women on his understanding of Islamic law and not Quranic verses or hadith.

Fiqh is an Arabic word that literally means "understanding;" however, I use the term to mean "legal rulings." Issues of authority are implicit when speaking of fiqh because legalities are a strategy to impart order into social relations. In the first century after the Prophet, the community of Muslims made regulations based on local customs and slowly a system of rules emerged based on who the leader was with specialists that created different legal schools of thought: Maliki, Shafii, Hanbali, Hanafi, and Zahiri.

The Malik school is based on jurist Malik ibn Anas who described laws based on the practice of those who have come before and are therefore closer to the Prophet. Malik rationale posits that the habits of the first generations of the Prophet should be codified into cross-cultural statutes. The Shafii legal school of thought supported by Imam al-Shafii did not accept custom as 
a valid basis for law, but advocated for laws based on the Quran and the Prophet's actions while extrapolating principles from these sources to apply to new situations through reasoning. The third legal system, the Hanbali school, was inspired by Ahmad ibn Hanbal who allowed for laws based on the Quran and Prophet's actions with less room for legal reasoning and more focus on literal interpretations of hadith. This school had such a small following that it most likely would have died out if not for Muhammad ibn Abd al-Wahhab who founded the Wahhabi or Salafi movement in the $18^{\text {th }}$ century. ${ }^{42}$ While the Hanbali approach does allow for logical reasoning and analogy in reaching legal decisions, the Wahhabi approach follows the most strict literal reading of scriptures. Saudi Arabia is the only country to officially adopt this method as legitimate.

Imam Kelapa Hanifa had a liberal methodology for decision making and was the founder of the Hanafi school that was in favor using reason and analogy to determine problems and find solutions while being loyal to the Quran and Prophet's actions. Finally, the last major Sunni orthodox school, the Zahiri approach, formed under the guidance of Dawud ibn Khalaf al-Zahiri longed to synthesize the previous four schools by declaring that everything not clearly forbidden is allowed. The Zahiri perspective did not accept custom or analogy as final edicts but returned to scriptures with a critical eye allowing the text with the most explicit meanings, and corroborating chain of narration of the Prophets words and deeds, to be privileged.

Muzayyin, a volunteer at the ponpes, thinks it is time for yet a new school of fiqh to emerge. He is studying for his master's degree in Islamic Philosophy and has been volunteering at the ponpes since 2011. He tells me he teaches the Quran and its elocution (tajwid) "because I want to change the old Islamic law since it is outdated and is practiced non-contextually today." I ask him to clarify what his means by non-contextually. "Today's era is very different than the Prophet's. I think Islam accepts waria because they are included in the Quran, in Surah Al-Hitam which makes evident that Islam not only acknowledges waria, but also accepts and embraces the existence of waria to live side by side with other genders. Muzayyin is referring to a pericope in chapter 24 entitled Light (Al-Hitam). The verse reads:

${ }^{42}$ Kugle, Homosexuality in Islam, 154. 
And tell believing women that they should lower their eyes, guard their private parts, and not display their charms beyond what is acceptable to reveal; they should draw their coverings over their necklines and not reveal their charms except to their husbands, fathers, their husbands' fathers, their sons, their husband's sons, their brothers, their brothers' sons, their sisters' sons, their womenfolk, their slaves, such men as attend them who have no desire, or children who are not yet aware of women's nakedness ..."43

Muz says the waria are people "with male genitalia but have a woman's soul." "What do you mean by soul?" I inquire."They have a woman's spirit, emotions, characteristics, and their sexual orientation is toward men." I wonder out loud, "What makes a man's soul?" "This is defined by sexual orientation. I call it human nature (fitrah) because it cannot be changed," he responds.

Muz considers the waria to be heterosexual although he says Islam does not have a problem with homosexual and bisexual Muslims since "the main objective of Islam is to be useful and beneficial to each other." He admits that Islam forbids anyone to change their anatomical parts just like it forbids tattoos, but he refers back to context, "there was no silicone technology or hair extensions in the Prophet's day." It is the emergence of new technologies and knowledge that did not exist in Arabia that motivates Mur reflect on why a new system of law is necessary for Islam to stay relevant

${ }^{43}$ Abdel Haleem, The Qur'an: A New Translation (Oxford: Oxford University Press, 2008), 222. 


\section{Bibliography}

Abdel Haleem, M. A. The Qur'an: A New Translation. Oxford: Oxford University Press, 2008.

Abrams, Lynn. Oral History Theory. London: Routledge, 2010.

Abu-Rabi', Ibrahim M. The Blackwell Companion to Contemporary Islamic Thought. Malden, MA: Blackwell Pub., 2006.

Aggleton, Peter, Regina Maria Barbosa, and Richard G. Parker. Framing the Sexual Subject: The Politics of Gender, Sexuality, and Power. Berkeley: University of California Press, 2000.

Al Rasheed, Madawi. Kingdom without Borders: Saudi Political, Religious and Media Frontiers. New York: Columbia University Press, 2008.

Aldrich, Robert. Colonialism and Homosexuality. New York, NY: Routledge, 2003.

Anderson, Benedict Richard O'Gorman. Language and Power: Exploring Political Cultures in Indonesia. Ithaca, N.Y: Cornell University Press, 1990.

Armour, Ellen T. and Susan M. St. Ville. Bodily Citations: Religion and Judith Butler. New York: Columbia University Press, 2006.

Azra, Azyumardi and Wayne Hudson. Islam Beyond Conflict: Indonesian Islam and Western Political Theory. Burlington, VT: Ashgate, 2008.

Bauman, Whitney. Religion and Ecology: Developing a Planetary Ethic. New York: Columbia University Press, 2014.

Bayat, Asef. Post-Islamism: The Changing Faces of Political Islam. New York, NY: Oxford University Press, 2013.

Beatty, Andrew. Varieties of Javanese Religion: An Anthropological Account. Cambridge: Cambridge University Press, 1999.

Blackwood, Evelyn. Falling into the Lesbi World: Desire and Difference in Indonesia. Honolulu: University of Hawai'i Press, 2010.

Boellstorff, Tom. A Coincidence of Desires: Anthropology, Queer Studies, Indonesia. Durham: Duke University Press, 2007.

_. "The Emergence of Political Homophobia in Indonesia: Masculinity and National Belonging." Ethnos 69, no. 4, 2004.

- The Gay Archipelago: Sexuality and Nation in Indonesia. Princeton: Princeton University Press, 2005.

_. "Playing Back the Nation: Waria, Indonesian Transvestites." Cultural Anthropology 19, no. 2, 2004. 
Boisvert, Donald L. and Jay Emerson Johnson. Queer Religion. Santa Barbara, Calif: Praeger, 2012.

Bouhdiba, Abdelwahab. Sexuality in Islam. London ; Boston: Routledge \& Kegan Paul, 1985.

Bowen, John Richard. Islam, Law, and Equality in Indonesia: An Anthropology of Public Reasoning. Cambridge: Cambridge University Press, 2003.

Brennen, Bonnie. Qualitative Research Methods for Media Studies. New York: Routledge, 2012.

Brettell, Caroline and Carolyn Fishel Sargent. Gender in Cross-Cultural Perspective. 2nd ed. Upper Saddle River, N.J: Prentice Hall, 1997.

Browne, Kath, Sally Munt, and Andrew K. T. Queer Spiritual Spaces: Sexuality and Sacred Places. Burlington, VT: Ashgate Pub, 2010.

Burton, Antoinette M. Gender, Sexuality and Colonial Modernities. New York: Routledge, 1999.

Butler, Judith. Undoing Gender. London: Routledge, 2004.

Butler, Judith and Athena Athanasiou. Dispossession: The Performative in the Political. Malden, MA: Polity, 2013.

Carrette, Jeremy R. Foucault and Religion: Spiritual Corporality and Political Spirituality. New York: Routledge, 2000.

Carver, Terrell and Véronique Mottier. Politics of Sexuality: Identity, Gender, Citizenship. New York: Routledge, 1998.

Chaves, Mark. "SSSR Presidential Address Rain Dances in the Dry Season: Overcoming the Religious Congruence Fallacy." Journal for the Scientific Study of Religion 49, no. 1 (2010): $1-14$.

Corrêa, Sonia. "The Yogyakarta Principles Principles on the Application of International Human Rights Law in Relation to Sexual Orientation and Gender Identity" 2007, http://yogyakartaprinciples.org

Dahm, Bernhard. History of Indonesia in the Twentieth Century. New York: Praeger, 1971.

Danaher, Geoff, Tony Schirato, and Jen Webb. Understanding Foucault. Thousand Oaks, Calif: Sage Publications, 2000.

Davidson, Julia O'Connell. Prostitution, Power, and Freedom. Ann Arbor: University of Michigan Press, 1998.

Davies, Sharyn Graham. Gender Diversity in Indonesia: Sexuality, Islam and Queer Selves. New York: Routledge, 2010.

DeLong Bas, Natana J. Wahhabi Islam: From Revival and Reform to Global Jihad. New York: Oxford University Press, 2004. 
Dijk, Kees van and Jajat Burhanuddin eds., Islam in Indonesia Contrasting Images and Interpretations. Amsterdam, Amsterdam University Press, 2013.

Doorn Harder. Women Shaping Islam: Indonesian Women Reading the Qur'an. Urbana: University of Illinois Press, 2006.

Dowling, Nancy. "The Javanization of Indian Art." Indonesia Indonesia. Ithaca no. 54 (1992): 117138.

Downing, Lisa. The Cambridge Introduction to Michel Foucault. New York: Cambridge University Press, 2008.

Effendy, Bahtiar. Islam and the State in Indonesia. Singapore: Ohio University Press Institute of Southeast Asian Studies, 2003.

Ekins, Richard, Richard Ekins, and Dave King. Blending Genders: Social Aspects of CrossDressing and Sex Changing. New York: Routledge, 1996.

Elliot, Patricia. Debates in Transgender, Queer, and Feminist Theory: Contested Sites. Burlington, VT: Ashgate Pub, 2010.

Esposito, John L. and Yvonne Yazbeck Haddad. Islam, Gender, \& Social Change. New York: Oxford University Press, 1998.

Fadl, Abou El. Speaking in God's Name: Islamic Law, Authority and Women. Oxford: Oneworld, 2001.

Fadl, Abou El, Deborah Chasman, and Joshua Cohen. Islam and the Challenge of Democracy. Princeton, N.J: Princeton University Press, 2004.

Geertz, Clifford. The Interpretation of Cultures: Selected Essays. New York: Basic Books, 1973.

Goody, Jack. Myth, Ritual and the Oral. New York: Cambridge University Press, 2010.

Habib, Samar. Islam and Homosexuality. Santa Barbara, Calif: Praeger, 2010.

Haj, Samira. Reconfiguring Islamic Tradition: Reform, Rationality, and Modernity. Stanford, Calif: Stanford University Press, 2009.

Hasan, Noorhaidi. Laskar Jihad: Islam, Militancy, and the Quest for Identity in Post-New Order Indonesia. Ithaca, N.Y.: Southeast Asia Program Publications, Southeast Asia Program, Cornell University, 2006.

Henking, Susan E. Que(e)rying Religion: A Critical Anthology. edited by Comstock, Gary David New York: Continuum, 1997.

Herdt, Gilbert H. Third Sex, Third Gender: Beyond Sexual Dimorphism in Culture and History. New York: Zone Books, 1994.

Highwater, Jamake. The Mythology of Transgression: Homosexuality as Metaphor. New York: Oxford University Press, 1997. 
Hines, Sally. Gender Diversity, Recognition and Citizenship: Towards a Politics of Difference. Hampshire: Palgrave Macmillan, 2013.

Hines, Sally and Tam Sanger. Transgender Identities: Towards a Social Analysis of Gender Diversity. New York: Routledge, 2010.

Hitlin, Steven. Moral Selves, Evil Selves: The Social Psychology of Conscience. $1^{\text {st }}$ ed. New York: Palgrave Macmillan, 2008.

Holt, P. M. The Cambridge History of Islam. Cambridge Eng: University Press, 1970.

Jeffreys, Sheila. Gender Hurts: A Feminist Analysis of the Politics of Transgenderism. Abingdon, Oxon: Routledge, 2014.

Kang D.B. "Kathoey 'in Trend': Emergent Genderscapes, National Anxieties and the ReSignification of Male-Bodied Effeminacy in Thailand ${ }^{1}$." Asian Studies Review 36, no. 4 (2012): 475-494.

Kassam, Zayn. Women and Islam. Santa Barbara, Calif: Praeger, 2010.

Keskin, Tugrul. The Sociology of Islam: Secularism, Economy and Politics. 1st ed. Reading, UK: Ithaca Press, 2011.

Kugle, Scott Alan. Homosexuality in Islam: Critical Reflection on Gay, Lesbian, and Transgender Muslims. Oxford: Oneworld, 2010.

Sufis \& Saints' Bodies : Mysticism, Corporeality, \& Sacred Power in Islam. Chapel Hill: University of North Carolina Press, 2007.

Kulick, Don. Travesti: Sex, Gender, and Culture among Brazilian Transgendered Prostitutes. Chicago: University of Chicago Press, 1998.

Kurzman, Charles. Liberal Islam: A Source Book. New York: Oxford University Press, 1998.

Laffan, Michael Francis. The Makings of Indonesian Islam: Orientalism and the Narration of a Sufi Past. Oxford, England: Princeton University Press, 2011.

Leaman, Oliver. Controversies in Contemporary Islam. New York: Routledge, 2014.

Lubis, Firman and Anke Niehof. Two is Enough: Family Planning in Indonesia Under the New Order 1968-1998. Leiden: KITLV Press, 2003.

Madinier, Rémy and Michel Picard. The Politics of Religion in Indonesia: Syncretism, Orthodoxy, and Religious Contention in Java and Bali. Abingdon, New York: Routledge, 2011.

Mahmood, Saba. Politics of Piety: The Islamic Revival and the Feminist Subject. Princeton, N.J: Princeton University Press, 2005.

Manalansan, Martin F. Global Divas: Filipino Gay Men in the Diaspora. Durham: Duke University Press, 2003. 
Means, Gordon Paul. Political Islam in Southeast Asia. Boulder: Lynne Rienner Publishers, 2009.

Meijer, Roel. Global Salafism: Islam's New Religious Movement. New York: Columbia University Press, 2009.

Mernissi, Fatima. The Veil and the Male Elite a Feminist Interpretation of Women's Rights in Islam. Cambridge, Mass: Perseus Books, 1991.

Moertono, Soemarsaid. "State and Statecraft in Old Java; a Study of the Later Mataram Period, 16th to 19th Century." Modern Indonesia Project, Southeast Asia Program, Dept of Asian Studies, Cornell University, 1968.

Murray, Stephen O. and Will Roscoe. Islamic Homosexualities: Culture, History, and Literature. New York: New York University Press, 1997.

Murtagh, Ben. Genders and Sexualities in Indonesian Cinema: Constructing Gay, Lesbi and Waria Identities on Screen. New York: Routledge, 2013.

Najmabadi, Afsaneh. Professing Selves: Transsexuality and Same-Sex Desire in Contemporary Iran. Durham; London: Duke University Press, 2014.

Nanda, Serena. Gender Diversity: Crosscultural Variations. 2nd ed. Long Grove, III: Waveland Press, 2014.

Nanda, Serena. Neither Man nor Woman: The Hijras of India. Belmont, Calif.: Wadsworth Pub. Co., 1990.

Noor, Farish and Martin van Bruinessen. The Madrasa in Asia: Political Activism and Transnational Linkages. Amsterdam: Amsterdam University Press, 2008.

Padilla, Mark. Love and Globalization: Transformations of Intimacy in the Contemporary World. 1st ed. Nashville, Tenn: Vanderbilt University Press, 2007.

Parry, Richard Lloyd. In the Time of Madness: Indonesia on the Edge of Chaos. New York: Grove Press, 2006.

Porter, Donald J. Managing Politics and Islam in Indonesia. New York: Routledge, 2002.

Povinelli, Elizabeth. "Radical Worlds: The Anthropology of Incommensurability and Inconceivability." Annual Review of Anthropology 30, (2001): 319.

Pringle, Robert. Understanding Islam in Indonesia: Politics and Diversity. Honolulu: University of Hawaii Press, 2010.

Puar, Jasbir K. Terrorist Assemblages: Homonationalism in Queer Times. Durham: Duke University Press, 2007.

Ritchie, Donald A. Doing Oral History: A Practical Guide. 2nd ed. Oxford: Oxford University Press, 2003. 
Robinson, Kathryn May. Gender, Islam, and Democracy in Indonesia. New York, NY: Routledge, 2009.

Rosenberg, Marshall B. Nonviolent Communication: A Language of Life. 2nd ed. Encinitas, CA: PuddleDancer Press, 2003.

Santoso, Suwito. The Centhini Story: The Javanese Journey of Life: Based on the Original Serat Centhini. Tarrytown, N.Y.: Marshall Cavendish Editions, Marshall Cavendish Corp., 2006.

Schultz, Emily Ann. Dialogue at the Margins: Whorf, Bakhtin, and Linguistic Relativity. Madison, Wis: University of Wisconsin Press, 1990.

Sedgwick, Eve Kosofsky. Epistemology of the Closet. Berkeley: University of California Press, 1990.

Siapno, Jacqueline Aquino. Gender, Islam, Nationalism and the State in Aceh: The Paradox of Power, Co-Optation and Resistance. New York: Routledge, 2002.

Sigal, Pete. "Queer Nahuatl: Sahagun's Faggots and Sodomites, Lesbians and Hermaphrodites." Ethnohistory 54, no. 1, 2007.

Smith, Bianca and Mark Woodward. Gender and Power in Indonesian Islam: Leaders, Feminists, Sufis and Pesantren Selves. New York: Routledge, 2014.

Stryker, Susan and Stephen Whittle. The Transgender Studies Reader. New York: Routledge, 2006.

Sukma, Rizal. Islamic Thought and Movements in Contemporary Indonesia. Jakarta: Centre for Strategic and International Studies, 2007.

Volpi, Frédéric. Political Islam: A Critical Reader. New York: Routledge, 2011.

Woodward, Mark R. Islam in Java: Normative Piety and Mysticism in the Sultanate of Yogyakarta. Tucson: University of Arizona Press, 1989. 